\title{
Kriminalitet og retsbevidsthed - i Grønland
}

\author{
Af Flemming Balvig ${ }^{1}$
}

\begin{abstract}
A study toward public reactions to crime and victimization of crime has been carried out in Greenland. The methodological concept and the design of the study were based on earlier studies made in Denmark in 2006 and 2009, and because of this several comparisons can be made with Denmark. The attitudes were analyzed by using three different methods on representative samples of the population in Greenland. In the first study, the general or spontaneous sense of justice was measured by short questions in telephone interviews. The informed sense of justice was examined by presenting vignettes of six cases in a postal survey. The concrete sense of justice was studied through focus groups proposing reactions after having seen a mock trial of a crime case and having discussed the case in the group. The results from the different studies of attitudes towards crime and reactions to crime were finally compared to the actual reactions according to assessments from the courts and the police in Greenland. Considering that Greenland has a rather special criminal law, which put more emphasis on rehabilitation than is usual seen - and even more so if you go back in time - a major question and special for the study in Greenland, has been how the people view, what should be the guiding principle for public reactions to crime: Special prevention or repression?*
\end{abstract}

\section{Indledning}

I 2010 trådte såvel en ny kriminallov som en ny retsplejelov i kraft for Grønland. En nydannelse i retsplejeloven var indførelse af et råd, Rådet for Grønlands Retsvæsen, som ifølge GR-Rpl. § 742 skal varetage koordinationen mellem Grønlands selvstyre og rigsmyndighederne om kriminal- og retsplejelovgivningen, herunder udvikle det lovgivningsmæssige grundlag, ivorksatte forskning i forbindelse hermed (min kursivering) og følge de enkelte retsmyndigheders funktion og uddannelsesbehov. Rådet består af 13 medlemmer: landsdommeren i Grønland, dommeren ved Retten i Grønland, politimesteren i Grønland, lederen af

* Title in English: Crime and the Public Sense of Justice - in Greenland. 
kriminalforsorgen i Grønland, Kanukoka, en advokat, en forsvarer, en universitetsloerer (min kursivering), to repræsentanter for Grønlands selvstyre og repræsentanter for Justitsministeriet, Domsstolsstyrelsen og Direktoratet for Kriminalforsorgen. Siden rådets nedsættelse har formand for rådet været nu tidligere højesteretsdommer Per Walsøe, og undertegnede har af justitsministeren været beskikket i funktionen som universitetslærer.

Et af det grønlandske selvstyres første ønsker til rådet, for så vidt angår den forskningsmæssige del, har været gennemførelse af en retsbevidsthedsundersøgelse. Motivationen herfor har været den særlige karakter, som kriminaliteten og det kriminalretlige system har i Grønland, samt de i 2010 gennemførte ændringer, der var et resultat af mange års forarbejde, ikke mindst i Den Grønlandske Retsvæsenskommission (jf. Betænkning nr. 1442/2004). Spørgsmålet har været, hvorvidt befolkningen kender til de grundlæggende træk i det grønlandske kriminalretlige system, og hvilke følelser og holdninger man har i den forbindelse. Det har måske også været en del af motivationen, at lignende undersøgelser var blevet gennemørt i Danmark i 2006 og 2009 (Balvig, 2006; 2010), og i 2009 tillige i Norge, Sverige, Finland og Island (Balvig et al, 2010; 2011; 2015; Olaussen, 2011), og det har i hvert fald været et bagvedliggende ønske at have et kriminalretligt system, der er i overensstemmelse med befolkningens grundlæggende ønsker og værdier. Denne politiske drivkraft bag undersøgelsens tilblivelse har ikke i tilnærmelsesvis samme grad ligget bag de øvrige nordiske undersøgelsers tilblivelse.

\section{Undersøgelserne ${ }^{2}$}

I forlængelse heraf gennemførtes i regi af Rådet for Grønlands Retsvæsen i 2014 en undersøgelse af retsbevidsthed i den grønlandske befolkning. ${ }^{3}$

Retsbevidsthedsundersøgelsen i Grønland består i virkeligheden af et kompleks af fire forskellige delundersøgelser, som vi for overskuelighedens skyld kan benævne: Telefonundersøgelsen, Postundersøgelsen, Fokusgruppeundersøgelsen og Praksisundersøgelsen. Det grundlæggende metodiske oplæg og undersøgelsesdesign afspejler den fremgangsmåde, der blev skabt og anvendt i undersøgelserne i Danmark i 2006 (og efterfølgende igen i Danmark samt i de øvrige andre nordiske lande i 2009) (Balvig, 2015a). ${ }^{5}$

\subsection{Telefonundersøgelsen}

Det primære formål med telefonundersøgelsen har været at forsøge at give et billede af den grønlandske befolknings generelle holdninger til kriminalitet og foranstaltninger over for kriminalitet, det der ofte betegnes som retsfølelsen, eller 
mere specifikt den generelle retsfølelse eller den spontane retsfølelse. De mulige svarpersoner blev ud fra deres telefonnumre udvalgt med henblik på at kunne udgøre et repræsentativt udsnit af 18-74-årige personer, bosiddende i Grønland. Også personer med taletidskort har kunnet inddrages i udvælgelsesproceduren. Telefonundersøgelsen blev foretaget i første kvartal 2014, og der opnåedes brugbare telefoniske interviews med i alt 696 personer.

Geografisk set viser der sig blandt de 696 respondenter at være en vis overrepræsentation af beboere fra Diskobugt-området. Respondenter fra bygder er lidt underrepræsenteret i forhold til respondenter fra byer. Imidlertid bor der lidt flere i bygder om sommeren end om vinteren (hvor undersøgelsen er foretaget), ligesom den konstante fraflytning fra bygder formentlig også har reduceret andelen med et par decimaler. Kønsfordelingen blandt respondenterne er meget tæt på den faktiske kønsfordeling blandt 18-74-årige bosiddende i Grønland. Også aldersfordelingen blandt de 18-74-årige er tæt på den faktiske aldersfordeling i Grønland.

Interviewene har gennemsnitligt varet omkring 20 minutter. Der blev anvendt et spørgeskema med i alt 39 hovedspørgsmål om kriminalitet og foranstaltninger over for kriminalitet, fire betingede spørgsmål (tillægsspørgsmål) og otte baggrundsspørgsmål (om køn, alders osv.). Ét af hovedspørgsmålene er kun stillet til kvindelige respondenter.

For at kunne vurdere om spørgsmålsformulering o.lign. påvirker de svar, man får, er der for ni af hovedspørgsmålenes vedkommende udformet to eller flere varianter af spørgsmålsformuleringen og/eller af svarmuligheder. Disse er placeret i tilsammen fire forskellige spørgeskemavariationer, og respondenterne er efter et tilfældighedsprincip blevet interviewet efter et af disse fire skemaer. Som det også gerne skulle være, foreligger der så også svar på omtrent lige mange af de fire spørgeskemavariationer (fra 170 til 180).

Det har været op til svarpersonerne, om de har villet interviewes på grønlandsk eller dansk. 83 pct. af interviewene blev gennemført på grønlandsk, 17 pct. på dansk.

For at vurdere om svarene kan være blevet påvirket af, hvem man er interviewet af, foreligger der for hvert enkelt interview oplysninger om, hvem intervieweren har været; interviewerens køn og alder - samt interviewerens indtryk af, om den interviewede har været alene ved interviewet, har givet sig god tid, og om den interviewede har svaret åbent og ærligt.

I nærværende artikel er det hovedsageligt resultater fra telefonundersøgelsen, der gengives, hvorfor fremgangsmåden mv. i de øvrige - mere komplekse - undersøgelser kun kort skal gengives her (se nærmere herom i Balvig, 2015b). 


\subsection{Postundersøgelsen}

Et tilsigtet repræsentativt udvalg af de 18-74-årige har med posten fået tilsendt et skema, hvor der på forsiden står: Hvordan vil du dømme? Skemaet indledes med en beskrivelse af mulige foranstaltninger (som det hedder i Grønland), således som de er oplistet i den grønlandske kriminallov. Mulighederne er suppleret med konfliktråd, som endnu ikke findes i Grønland, men hvor en forsøgsordning er undervejs.

Herefter følger så et antal konkrete sager, som svarpersonerne anmodes om at gætte på, hvordan de ville blive pådømt ved en grønlandsk domstol; hvordan man tror befolkningen flest ville dømme, samt hvordan man selv ville dømme. De enkelte sager er beskrevet på en A-4 side, inklusiv beskrivelse af personlige forhold hos tiltalte. Sagerne vedrører partnervold, indsmugling af hash, seksuelt misbrug af mindreårig, røveri, kontaktvoldtægt, indsmugling af hash samt en kriminalforsorgssag, hvor det drejer sig om en indsats muligheder for at arbejde uden for anstalt og komme på udgang. De fire førstnævnte sager har også været anvendt i de tilsvarende danske og øvrige nordiske retsbevidsthedsundersøgelser, mens hashindsmuglingssagen og kriminalforsorgssagen er specifik for den grønlandske undersøgelse.

Formålet med postundersøgelsen har været at forsøge at afdække den såkaldt informerede retsfølelse.

Postspørgeskemaet er et ganske kompliceret spørgeskema at besvare. Dels kræver det megen læsning, og dels stiller selve måden at svare på også store krav til den svarendes færdigheder og forudsætninger. Dette gør sig ikke mindst gældende i dets grønlandske udformning på grund af det grønlandske sprogs natur. Svarprocenter mv. er i skrivende stund ikke endelig opgjort, men den samlede effektive svarprocent kommer til at ligge mellem 20 og 25 pct., og det ville ikke overraske, hvis der viser sig større skævheder med hensyn til, hvem der har svaret. Skemaet er klart lettere at gå til og besvare for dansksprogede sammenlignet med grønlandsksprogede, og også for personer med en længerevarende uddannelse sammenholdt med personer med en kort eller begrænset skoleuddannelse.

\subsection{Fokusgruppeundersøgelsen}

Hensigten med fokusgruppeundersøgelsen har været at få et repræsentativt udsnit af de 18-74-årige i Grønland til, fordelt på 18 grupper, at diskutere og overveje, hvordan der (skal) dømmes i konkrete sager. Til brug herfor blev der produceret to film, en der viste en retssag baseret på ovennævnte partnervoldssag, og en der viste en retssag baseret på kontaktvoldtægtssagen. I filmene følges sagerne frem til umiddelbart før proceduren, dvs. man præsenteres ikke for hverken anklage- 
myndighedens eller forsvarerens konkrete bud på, hvordan der skal foranstaltes, eller begrundelserne herfor. Sproget i filmene er grønlandsk, men filmene er suppleret med undertekster på dansk. Det er skuespillere, der varetager rollerne som tiltalte og vidner, mens rollerne som dommer, forsvarer og anklager varetages af personer, der også i det virkelige liv fungerer i disse roller.

Mødedeltagerne er blevet inviteret til et 2-3 timers møde om kriminalitet og uden nogen nærmere specifikation, det være sig med hensyn til det nærmere indhold, eller måden det skulle diskuteres på.

Efter en kort introduktion ved en neutral mødeleder udfyldtes individuelt et spørgeskema, der grundlæggende svarede til det, der blev anvendt i postundersøgelsen, og svarpersonen påførte skemaet et nummer. Dog er kriminalforsorgssagen ikke med i fokusgruppeundersøgelsen. Besvarelsen af spørgeskemaet har haft den indirekte funktion, at alle tilførtes viden om, hvordan der kan foranstaltes, og hvad de enkelte foranstaltninger nærmere går ud på. En særlig fordel ved fokusgruppeundersøgelsen er, at der her har været en mødeleder tilstede, der har kunnet bistå med tekniske spørgsmål i forbindelse med spørgeskemabesvarelsen, det være sig på grønlandsk eller dansk. Skemaerne er derfor utvivlsomt udfyldt mere fyldestgørende, mindre »skævt« og mere korrekt. Efter spørgeskemaudfyldningen vistes en af de to indspillede film, uden at der eksplicit blev gjort opmærksom på, at retssagen i filmen faktisk vedrørte en af de sager, deltagerne lige havde pådømt i spørgeskemaet. Umiddelbart efter filmen udfyldtes igen individuelt et spørgeskema, der denne gang alene vedrørte, hvordan man troede retspraksis ville være i den sag, man lige havde set på film, og hvordan man selv ville dømme. Skemaet påførtes samme nummer som det første skema. Herefter overgik man til indbyrdes at diskutere sagen. Diskussionen var struktureret på den måde, at man tog hver mulig foranstaltning op for sig, og diskuterede, hvad der kunne være henholdsvis fordele og ulemper ved at anvende den enkelte foranstaltning $\mathrm{i}$ den konkrete retssag, der var blevet vist på film.

Diskussionen af de forskellige foranstaltningers fordele og ulemper som mulig dom i den konkrete sag afsluttedes med, at deltagerne for tredje gang udfyldte et spørgeskema. Dette skema var identisk med skema nummer to, dvs. det vedrørte hvordan man nu - efter at have haft yderligere muligheder for at tænke over og at have gennemgået de mulige foranstaltninger - ville dømme i sagen. Igen påførtes et nummer, der har haft den funktion, at deltagerne på den ene side har kunnet bevare anonymitet i deres besvarelser, og på den anden side har muliggjort en analyse af, hvordan de enkelte besvarer henholdsvis skema et, to og tre og eventuelle ændringer heri undervejs. 
Til sidst på mødet opfordredes deltagerne til i plenum, hvis de havde lyst, at tilkendegive, om de havde skiftet mening undervejs, og i givet fald hvorfor. Mødelederen spurgte også, om man troede, man kunne være blevet enige, hvis man nu havde været en jury, og hvad foranstaltningen så skulle være.

Et enkelt af fokusgruppemøderne måtte opgives på grund af vejrlig og transportproblemer, så man endte med i alt 17 møder, med i alt 199 deltagere. De enkelte møder adskilte sig indbyrdes med hensyn til, hvor i Grønland de foregik, om det anvendte sprog var grønlandsk eller dansk, hvilken aldersgruppe der deltog, og hvilken konkret film/sag der blev vist/fokuseret på. For samtlige grupper blev der tilstræbt en tilnærmelsesvis lige kønsfordeling, samt en majoritet af deltagere, der på det generelle plan syntes, at straffene/foranstaltninger var for milde i Grønland, for sådan viste telefonundersøgelsen, at det forholdt sig. Omkring syv ud af ti af deltagerne gik ind til møderne med den overbevisning, at straffene/foranstaltningerne i Grønland gennemgående var for milde. Efterfølgende kontrol har vist, at dette ganske nøje svarer til holdningen i den grønlandske befolkning, jf. også nærmere herom i det følgende.

Retsfornuften er de holdninger og handlinger, den grønlandske befolkning ville have og udøve, hvis de selv var dommere i konkrete retssager, og ikke var bundet af at skulle forholde sig til eller følge retspraksis. Fokusgruppeundersøgelsen har været en bestræbelse på at kunne komme så nær denne situation som muligt, og er således undersøgelsens optimale bud på den grønlandske befolknings retsfornuft, eller hvis man skulle foretrække det: Den konkrete retsfølelse. ${ }^{7}$

\subsection{Praksisundersøgelsen}

I forskellige dele af undersøgelsen har der været et behov for at holde spørgeskemabesvarelser mv. op mod, hvordan det faktisk forholder sig, ikke mindst hvordan retspraksis faktisk er. Dette kunne måske lyde som en enkelt sag, men dels mangler der i Grønland »almindelige« og aktuelle præcise statistiske oplysninger for en del af de forhold, det kunne være relevant at belyse, og dels er der nok en større variation i retspraksis i Grønland end f.eks. i Danmark, ikke mindst fordi man kan sige, at dette sådan set er tilsigtet gennem en større betoning af "gerningspersonprincippet« ved valg af straf/foranstaltning i Grønland (mere herom i det følgende).

Landsdommerembedet i Grønland og Politiet i Grønland har gjort det optimale for at besvare de vanskelige spørgsmål om praksis m.v. 


\section{Kriminaliteten}

Den synsvinkel, der anlægges på kriminaliteten i de gennemførte undersøgelser, er ikke primært kriminaliteten som et problem i sig selv, men kriminaliteten som en mulig faktor til forståelse af og som en mulig forklaring på den grønlandske befolknings retsbevidsthed.

Fokus er derfor på den del af kriminalitetsbilledet, der vedrører, hvad de 1874-årige har oplevet på egen krop (personkriminalitet) eller på egne besiddelser (ejendomskriminalitet), og uanset om dette så er blevet anmeldt til politiet eller ej.

For at kaste lys over dette har telefonundersøgelsen indeholdt en række spørgsmål om, hvorvidt man inden for en nærmere specificeret periode har oplevet sig udsat for forskellige former for kriminallovsovertrædelser, såsom vold, tyveri mv. Telefonundersøgelsen har dermed fungeret som en såkaldt »offerundersøgelse«.

En tilsvarende offerundersøgelse blev gennemført i Grønland i 1995/96. Herved bliver det muligt at se, om der er sket ændringer i den grønlandske befolknings udsathed for kriminalitet i de seneste knapt 20 år. Undersøgelsen i 1995/96 gennemførtes som et led i Den Grønlandske Retsvæsenskommissions arbejde, og de tekniske detaljer ved og resultater af undersøgelsen er nærmere omtalt andetsteds (Skydsbjerg, 1996; Balvig, 1999a). Undersøgelsen i 1995/96 gennemførtes som postspørgeskemaundersøgelse, og antallet af besvarelser i aldersgruppen 18 til 74 år var 2.630.

Et referencepunkt, der yderligere kan belyse den grønlandske befolknings udsathed for kriminalitet, er tilsvarende undersøgelser gennemført blandt 18-74årige i Danmark i henholdsvis 1995/96 og i 2013 (Balvig, 1998; Boesen Pedersen et al, 2014). I begge tilfælde har der været tale om telefoninterviewundersøgelser. Antallet af gennemførte interviews var i 1995/96 25.218 og i 2013 11.017.

\subsection{Ejendomsforbrydelser}

En ud af ni (11 pct.) af de 18-74-årige tilkendegav i telefonundersøgelsen i Grønland i 2013/14, at de inden for det seneste år havde været udsat for tyveri, jf. opstilling 3.1.1.

Det var præcis det samme som i Danmark, og - med forbehold for stikprøveusikkerheden - et ganske markant fald i forhold til 1995/96, hvor det var omkring en ud af seks (16 pct.), der havde oplevet sig udsat for tyveri. Også i Danmark er der sket et fald fra 1995/96 og frem til den seneste undersøgelse.

Udsatheden for hærværk følger det samme mønster. Her er det 6 pct. i Grønland i 2013/14, der har oplevet sig udsat for hærværk, hvilket - stikprøveusikkerheden taget i betragtning - ligger på samme niveau som i Danmark 2013 (5 pct.). 
Igen er der tale om et fald i Grønland i løbet af den sidste snes år på omkring en tredjedel, og også i Danmark er der et fald.

Opstilling 3.1.1. Procent af de 18-74-årige der inden for det seneste år har oplevet sig udsat for tyveri og/eller harvaerk $i$ Grønland, 1995/96 og 2013/14, og i Danmark, 1995/96 og 2013

\begin{tabular}{lcccc}
\hline & \multicolumn{2}{c}{ GRØNLAND } & \multicolumn{2}{c}{ DANMARK } \\
\cline { 2 - 5 } & $1995 / 96$ & $2013 / 14$ & $1995 / 96$ & 2013 \\
\hline Tyveri & 16 & 11 & 14 & 11 \\
Hærværk & 9 & 6 & 8 & 5 \\
Tyveri og/eller hærværk & 19 & 14 & 18 & 14 \\
\hline
\end{tabular}

Ser vi samlet på ejendomskriminalitet, er det en ud af syv (14 pct.) blandt de 1874-årige Grønland i 2013/14, der inden for det seneste år forud for udspørgningstidspunktet har været udsat for tyveri og/eller hærværk. Det er nøjagtig den samme andel som i Danmark 2013 og tendensen er begge steder - som i øvrigt i en stor del af verden - et fald sammenlignet med situationen for et par årtier siden. En af de mere betydningsfulde globale forklaringer på den faldende tendens i tyverier mv. synes at være den øgede sikring og overvågning af ting, varer og besiddelser, og den heraf følgende øgning i vanskeliggørelsen af tyveri mv. og øgede opdagelsesrisiko.

Hvor anmeldestilbøjeligheden for tyveri var lavere i Grønland end i Danmark for en snes år siden, har dette ændret sig. Mens den har holdt sig nogenlunde konstant i Danmark, er den steget betydeligt i Grønland. Stigningen har været så kraftig, at anmeldelsestilbøjeligheden for tyveri (og hærværk) nu er på niveau med situationen i Danmark, måske endog lidt højere.

Den faldende tendens for forekomsten af ejendomsforbrydelser som tyveri og hærværk kan også iagttages i de registrerede ejendomsforbrydelser, dvs. i de ejendomsforbrydelser der ved anmeldelse eller på anden måde er kommet til politiet kundskab. Faldet i den registrerede kriminalitet er ikke så kraftigt som i den faktiske kriminalitet målt ved offerundersøgelsen, hvilket formentlig primært beror på, at anmeldelsestilbøjeligheden samtidig er steget.

\subsection{Personforbrydelser}

En ud af ni, 11 pct., har i 2013/14 i Grønland oplevet sig udsat for vold og/eller alvorlige trusler om vold inden for det seneste år. Det er ikke blot i sammenlig- 
ning med Danmark - hvor det i $2013 » k u n «$ var en ud af tyve, 5 pct. - at voldsniveauet i Grønland målt på denne måde er højt. Det er det også internationalt/globalt. Det er meget få lande i verden, hvor niveauet af vold og trusler om vold, som i Grønland, ligger på niveau med udsatheden for tyveri.

Endvidere er det i særdeleshed med hensyn til selve volden, at Grønland såvel absolut som relativt set ligger højt. Hvor 1 ud af 100 i Danmark udsættes for vold i løbet af et år, er det 1 ud af 20 i Grønland - altså i størrelsesordenen fem gange så mange. Blandt 72 lande i verden, hvor man i perioden fra 1995 til 2005 har undersøgt udsatheden for vold (»assault«), er der kun ét land, hvor der findes en højere udsathed for vold end i Grønland, og forskellen er ikke engang statistisk signifikant (Van Dijk, 2008). Det er Sydafrika, hvor 6 pct. har været udsat. Zimbabwe placerer sig næsthøjest blandt de 72 lande med 5 pct. - altså det samme som i Grønland. Herefter kommer Swaziland med 4 pct. og Zambia med 3 pct. I de resterende 68 lande er det 3 pct. eller færre - og for langt de fleste 2 pct. eller færre - der har oplevet sig udsat for vold inden for det seneste år forud for udspørgningstidspunktet.

Den positive udvikling, vi har kunnet konstatere for ejendomskriminalitetens vedkommende, genfindes ikke for vold, jf. opstilling 3.2.1. Også i 1995/96 var det en ud af ni, 11 pct., der inden for det seneste år havde været udsat for vold og/eller alvorlige trusler om vold. Dette skal ses i lys af, at der i Danmark har været et mindre fald i volden, og at der også internationalt i mange lande er sket et fald i denne form for kriminalitet.

Opstilling 3.2.1. Procent af de 18-74-årige der inden for det seneste år har oplevet sig udsat for vold og/eller alvorlige trusler $i$ Grønland, 1995/96 og 2013/14, og i Danmark, 1995/96 og 2013

\begin{tabular}{lcccc}
\hline & \multicolumn{2}{c}{ GRØNLAND } & \multicolumn{2}{c}{ DANMARK } \\
\cline { 2 - 5 } & $1995 / 96$ & $2013 / 14$ & $1995 / 96$ & 2013 \\
\hline Vold & $\mathrm{x}$ & 5 & 2 & 1 \\
Alvorlige trusler & $\mathrm{x}$ & 9 & 4 & 4 \\
Vold og/eller alvorlige trusler & 11 & 11 & 6 & 5 \\
\hline
\end{tabular}

$\mathrm{x}=$ oplysninger foreligger ikke.

Mellem forskellige befolkningsgrupper og mellem forskellige dele og områder af Grønland findes der betydelige forskelle i risikoen for at blive udsat for vold og/eller alvorlige trusler om vold (2013/14). Dette gælder dog ikke med hensyn 
til, om man bor i by eller bygd; her er forskellen minimal. Der er heller ingen større forskel mellem risikoen for personer født i Grønland, og personer der ikke er født i Grønland.

Mænd har en lidt større risiko end kvinder: 13 pct. over for 9 pct. Dette beror udelukkende på, at unge mænd (18-29 år) har en betydelig større risiko end unge kvinder. Hvor næsten hver tredje af de unge mænd, 30 pct., har oplevet sig udsat for vold eller alvorlige trusler inden for det seneste år, er det $» k u n \ll$ hver femte af de unge kvinder (20 pct.). Er man 30-74 år ligger risikoen på omkring 10 pct., uanset om man er mand eller kvinde.

Der eksisterer en tydelig social slagside i risikoen for at blive udsat for vold, idet personer uden uddannelse eller med meget kort uddannelse løber en større risiko end andre. Ufaglærte og personer beskæftigede som fiskere eller fangere løber en større risiko end faglærte og funktionærer.

Geografisk set ligger risikoen over det gennemsnitlige i Nord-, Øst- og Sydgrønland (14-15 pct.), mens den ligger betydeligt under det gennemsnitlige i Midtgrønland (4 pct.). Niveauet i Midtgrønland svarer således til niveauet i Danmark som helhed. Diskobugten ligger noget lavere end det gennemsnitlige (8 pct.), mens Nuuk placerer sig omkring det gennemsnitlige (11 pct.).

Op mod halvdelen af de tilfælde af vold og alvorlige trusler om vold, man har været udsat for, er blevet anmeldt til politiet, såvel i 1995/96 som i 2013/14; det har ikke ændret sig. Det er såvel sammenlignet med Danmark som den øvrige verden, hvori voldsofferundersøgelser er blevet foretaget, en meget høj anmeldelsestilbøjelighed. I Danmark er anmeldelsestilbøjeligheden steget fra 1995/96 til 2013, men til trods herfor ligger anmeldestilbøjeligheden for vold og trusler om vold også i 2013/14 på et klart højere niveau i Grønland end i Danmark.

En del af forskellen mellem Grønland og Danmark kan bero på, at voldssager såvel relativt som absolut set oftere kommer til politiets kundskab på anden måde end ved offerets egen anmeldelse, f.eks. via naboer eller andre der ringer til politiet. I 1995/96 var det hvert tredje af de tilfælde, som svarpersonerne havde været udsat for, og som var kommet til politiets kundskab i Grønland, der var kommet til politiets kundskab på anden måde end ved offerets anmeldelse. Det var især typisk for den vold, der forekommer i hjemmet - ligesom 1995/96-undersøgelsen i øvrigt viste, at en usædvanlig stor andel af den samlede vold i Grønland netop forekom i hjemmet. Undersøgelsen i 2013/14 giver ikke tilsvarende mulighed for at vurdere, på hvilken måde politiet i Grønland i givet fald har fået kundskab om volden.

En af konsekvenserne af det noget mindre »mørketal« vedrørende vold og trusler blandt voksne i Grønland er, at sammenligninger mellem den politiregi- 
strerede voldskriminalitet i Grønland og Danmark kommer til at give et noget overdrevet billede af, hvor stor forskellen faktisk er.

En anden central del af personforbrydelserne er seksualkriminaliteten. Den er ganske vanskelig at belyse $i$ en telefoninterviewundersøgelse, dels pga. vanskeligheder med spørgsmålsformulering og dels pga. mulige problemer med svarvillighed. Tilsvarende gør sig for så vidt også gældende for vold og trusler, men problemerne er af endnu større mulig betydning ved seksualkriminalitet.

Den kvindelige halvdel af svarpersonerne er blevet spurgt, om de inden for de seneste fem år forud for udspørgningstidspunktet har været udsat for, at nogen har tvunget dem til samleje eller forsøgt at tvinge dem til samleje. Kun kvinderne blev spurgt, fordi en forprøve viste, at en del mænd, ærgerligt nok, syntes, at et sådant spørgsmål var lidt »for sjovt« - ærgerligt fordi det kunne være lige så væsentligt at få blotlagt mændenes udsathed på dette område.

En ud af hver tyve kvinder, 5 pct., svarede bekræftende på, at de havde været udsat for tvangssamleje eller forsøg herpå inden for de seneste fem år. Det er fem gange så mange som i Danmark, hvor 1 pct. af kvinderne i 2013 havde været udsat. Der er ikke stillet et helt tilsvarende spørgsmål i tidligere undersøgelser, så vi har ikke mulighed for at belyse den tidsmæssige udvikling.

Det fordeler sig med omtrent lige mange, der har været udsat for fuldbyrdet tvangssamleje og forsøg på tvangssamleje.

Den præcise ordlyd af spørgsmålet og svarmulighederne var følgende:

»Har du inden for de seneste 5 år været udsat for, at nogen har tvunget eller forsøgt at tvinge dig til samleje?

\section{INTERV: Kun ét kryds (ved det alvorligste)}

1. Ja, jeg er blevet tvunget til samleje

2. Ja, men det blev ved forsøget

3. Nej, men jeg har været udsat for anden form for seksuel krænkelse

4. Nej, slet ikke«

Der er altså også muligt som svar at medtage anden sexkrænkelse end tvangssamleje, og forhåbningen med denne måde at spørge/svare på har været, at disse eventuelle andre seksuelle krænkelser hører til i den relativt alvorlige ende. »Seksuel krænkelse« er et vidt begreb, om end nok ikke så vidt som »seksuel chikane«, som ses anvendt i nogle undersøgelser.

På denne baggrund tillader vi os at omtale svar 1, 2 og 3 på spørgsmålet som udsathed for »alvorlig seksuel krænkelse«. Der er 3 pct. af kvinderne, der tilken- 
degiver at have været udsat for anden form for seksuel krænkelse (end tvangssamleje), og således i alt 8 pct. der har oplevet sig udsat for alvorlig seksuel krænkelse inden for de seneste fem år.

Det er de yngste kvinder, der har langt den største risiko. 17 pct. af de 18-29årige kvinder har oplevet sig udsat for alvorlig sexkrænkelse inden for de seneste fem år, og i næsten alle tilfælde har der været tale om tvangssamleje eller forsøg herpå. For kvinder på 30 år og derover er risikoen meget mindre, og her drejer det sig lige så ofte eller oftere om anden seksuel krænkelse end tvangssamleje. Særligt er tvangssamleje eller forsøg herpå yderst sjældent over for »ældre« kvinder, der er bosiddende $\mathrm{i}$ bygder.

Som ved vold har sexkrænkelserne social slagside. Blandt de bogligt uddannede har 3 pct. været udsat for alvorlig sexkrænkelse, mens det er fire gange så mange, 12 pct., blandt kvinder med kun folkeskoleuddannelse.

Den geografiske fordeling bliver meget usikker på grund af de små tal, men umiddelbart ser risikoen for alvorlig sexkrænkelse ud til at være relativt høj i Nord-, Øst- og Sydgrønland (13-17 pct.), mens den er relativt lav i Nuuk, Diskobugten og Midtgrønland (4-7 pct.). Med endnu en betoning af de statistisk set usikre tal fremtræder byerne Nanortalik, Qaqortoq og Tasiilaq umiddelbart som byer med særlig stor risiko (30-40 pct.).

Hvis alle kvinder i et telefoninterview har svaret åbent og ærligt og efter bedste evne på et spørgsmål om, hvorvidt de har været udsat for alvorlig seksuel krænkelse, skulle vi forvente, at det ikke har nogen betydning, hvem de er blevet interviewet af og/eller de omstændigheder, hvorunder de blev interviewet. Hvis svarene varierer med disse omstændigheder, tyder det på, at der samlet set er tale om en underrapportering, med mindre selvfølgelig der er tale om praleri el.lign., hvilket næppe er særligt sandsynligt her.

Kvinderne er efter et tilfældighedsprincip blevet interviewet af enten en mand eller en kvinde, og som man kunne vente, er det også præcis den samme andel, der på spørgsmålene om ejendomskriminalitet beretter, om de har været udsat herfor eller ej. Derimod er der ved spørgsmålet om seksuel krænkelse en betydelig forskel. Når kvinderne er blevet interviewet af mænd, er det 19 pct., der har svaret, at de har været udsat for en alvorlig seksuel krænkelse, mens det kun er 5 pct. af de kvinder, der er blevet interviewet af kvinder. For tvangssamleje eller forsøg herpå alene er procenterne henholdsvis $10 \mathrm{og} 3 \mathrm{pct}$. Disse forskelle er statistisk signifikante. Om årsagerne kan man kun gisne. Umiddelbart kunne man forestille sig, at en kvinde hellere ville berette om de ubehagelige oplevelser til en anden »ligestillet og ligesindet« kvinde. Måske beror det på, at mandlige interviewere i højere grad opleves og opfattes som beskyttere. Det er især i de inter- 
views, der er foregået på grønlandsk, hvor andelen af kvinder, der beretter om, at de har været udsat for seksuel krænkelse, øges, når det er en mandlig interviewer.

Intervieweren har registreret, om de generelt oplevede den, de interviewede, som åben og ærlig eller som mere forsigtig og undvigende. Blandt de interviewede kvinder, der oplevedes som åbne mv., tilkendegav 9 pct., at de havde været udsat for alvorlig seksuel krænkelse, mens det »kun« var 4 pct. blandt de forsigtige mv.

På dette grundlag mistænker vi, at der er tale om en betydelig underrapportering af de alvorlige seksuelle krænkelser, de interviewede kvinder har været udsat for. Måske er det ikke »kun« mindst en ud af 20 kvinder, der over en 5-årig periode har været udsat for tvangssamleje eller forsøg herpå, men mindst en ud af 10 ? Og måske er det ikke »kun« mindst en ud af 12 kvinder, der har været udsat for alvorlig seksuel krænkelse, men mindst en ud af hver femte? Med hensyn til de unge kvinder (18-29 år) er det måske mindst en ud af tre, der har været udsat for en alvorlig seksuel krænkelse inden for de seneste fem år, og måske mindst en ud af fire, der har været udsat for tvangssamleje eller forsøg herpå.

Blandt de kvinder, der inden for de seneste fem år havde oplevet sig udsat for tvangssamleje eller forsøg herpå, havde hver tredje - 33 pct. - anmeldt det til politiet eller politiet angives at have fået nys om det på anden vis. I de tilsvarende undersøgelser i Danmark ligger »anmeldelsesprocenten« på omkring 25.

Mange har også seksuelle krænkelser, der er sket, mens de var børn eller helt unge, med i ballasten. Alle, såvel mænd som kvinder, blev spurgt, om de en eller flere gange inden de fyldte 18 år var blevet udsat for, at nogen havde tvunget dem til samleje eller forsøgt herpå eller anden form for seksuel krænkelse. Det viste sig at være tilfældet for mellem hver femte og hver fjerde, 22 pct. - og mere end halvdelen af disse havde været udsat flere gange. 13 pct. af drengene havde været udsat for alvorlige seksuelle krænkelser som børn eller helt unge, og næsten hver tredje - 30 pct. - af kvinderne. Især for mændene var der en tendens til enteneller: Enten havde de ikke været udsat, eller også havde de været udsat ikke blot en enkelt gang, men flere gange. ${ }^{8}$

Barndomskrænkelserne har ikke samme grad af sammenhæng med svarpersonernes nuværende bopæl og sociale situation (uddannelse og beskæftigelse), som de krænkelser der er sket inden for de seneste fem år. Såvel de mænd som kvinder, der har fået en lang boglig uddannelse, har dog ikke i samme udstrækning været udsat for alvorlige seksuelle krænkelser som børn, som de personer der ikke har fået lang boglig uddannelse. De mænd, der på interviewtidspunktet boede i Nord-, Øst- eller Sydgrønland, havde i større omfang oplevet sig alvorligt seksuelt krænket som børn, end de mænd der aktuelt boede andetsteds i Grønland. For 
kvinder er der ikke større forskelle i forhold til deres aktuelle bosted, bortset fra en vis overhyppighed blandt kvinder bosiddende i Sydgrønland.

For mænd gør det ingen forskel, om de er interviewet af en mand eller en kvinde, mens det - som vedrørende de aktuelle erfaringer - gør en forskel for kvindernes vedkommende. Bemærkelsesværdigt nok er det dog her det omvendte: Det er blandt de kvinder, der har været udspurgt af kvinder, at flest beretter, at de er blevet alvorligt seksuelt krænket som børn: 32 pct., sammenlignet med 23 pct. af de kvinder, der er blevet interviewet af mænd.

15 pct. af de, der er blevet alvorligt seksuelt krænkede som børn, har anmeldt det til politiet eller politiet har fået nys om det på anden måde - 10 pct. for drengenes vedkommende og 17 pct. for pigernes.

Mere end hver tredje af de adspurgte kvinder, 36 pct., har enten oplevet sig udsat for alvorlig seksuel krænkelse, da de var børn. eller inden for de seneste fem år forud for udspørgningstidspunktet - eller bege dele (hvilket drejede sig om tre pct. af samtlige kvinder). For kvinder på 50 år og derover var det tæt ved halvdelen, 46 pct., og her skal man betænke, at en del af de tilsyneladende ikkeudsatte på grund af udspørgningsmetoden kan have været udsat for alvorlig seksuel krænkelse mellem det fyldte 18 år og frem til fem år før udspørgningstidspunktet.

\subsection{Samlet risiko}

Det er almindeligt i offerundersøgelser at udarbejde og analysere et samlet mål for udsathed for kriminallovsovertrædelser inden for en nærmere specificeret periode. Et sådant mål er naturligvis stærkt påvirkeligt over for hvilke lovovertrædelser, det er muligt at inddrage. Vi er begrænset til tyveri, hærværk, vold og alvorlige trusler, og på baggrund af det umiddelbart foregående er der især grund til at gøre opmærksom på, at seksualkriminalitet således ikke indgår. Andre eksempler på kriminallovsovertrædelser, der ikke indgår, er røveri, bedrageri og brandstiftelse. Endvidere ligger det i sagens natur, at såkaldt »offerløse« lovovertrædelser ikke indgår, såsom narkotikakriminalitet. 
Opstilling 3.3.1. Procent af de 18-74-årige, der inden for det seneste år har oplevet sig udsat for tyveri og/eller hoervaerk og/eller vold og/eller alvorlige trusler (»kriminalitet") i Grønland, 1995/96 og 2013/14, og i Danmark, 1995/96 og 2013

\begin{tabular}{lcccc}
\hline & \multicolumn{2}{c}{ GRØNLAND } & \multicolumn{2}{c}{ DANMARK } \\
\cline { 2 - 5 } & $1995 / 96$ & $2013 / 14$ & $1995 / 96$ & 2013 \\
\hline Pct. udsat for $»$ kriminalitet« & 25 & 22 & 23 & 17 \\
\hline
\end{tabular}

Af opstilling 3.3.1 fremgår, at det i 1995/96 var hver fjerde, 25 pct., af de 18-74årige i Grønland, der havde været udsat for »kriminalitet«, dvs. tyveri og/eller hærværk og/eller vold og/eller alvorlige trusler. Frem til 2013/14 er der et lille fald i udsatheden for kriminalitet, der, som vi har set, beror på et fald i ejendomskriminaliteten.

Udsatheden for »kriminalitet« var i 1995/96 en smule højere i Grønland end i Danmark. I 2013/14 er forskellen vokset, fordi risikoen for »kriminalitet« er faldet mere i Danmark end i Grønland.

Risikoen for at blive udsat for »kriminalitet« var i Grønland i 2013/14 næsten dobbelt så stor for mænd sammenlignet med kvinders risiko, 29 pct. over for 16 pct.

Generelt var det de unge, de 18-29-årige, der løb den største risiko (30 pct.), mens der ikke var nogen særlig forskel mellem de 30-49-åriges og de 50-74åriges risiko (ca. 20 pct.). Det er især de unge mænd, der løber en betydelig risiko for at blive udsat for »kriminalitet«, idet 41 pct. havde været udsat inden for det seneste år. Blandt de 30-74-årige mænd var det omkring hver fjerde, der var blevet udsat. De unge kvinder (18-29 år) havde kun halvt så stor risiko for at blive udsat for »kriminalitet« (19 pct.), og de unge kvinders risiko var kun lettere forhøjet i forhold til de 30-74-årige (15 pct.).

Uddannelsesmæssigt og beskæftigelsesmæssigt synes forskelle i risiko for »kriminalitet« især at afspejle underliggende forskelle i alder og i besiddelser (som muligt objekt for berigelseskriminalitet). Bl.a. viser det sig, at studerende og personer med en lang boglig uddannelse generelt har en højere risiko end andre.

Risikoen for at blive udsat for »kriminalitet« var noget højere i byer (23 pct.) end i bygder (17 pct.). Den var bemærkelsesværdig lav i Midtgrønland (7 pct.), og noget lavere end det gennemsnitlige i Diskobugten (17 pct.). For bosiddende i Nuuk var risikoen 25 pct., og endnu lidt større var den i Nord- og Østgrønland (27 pct.) og i Sydgrønland (28 pct.). ${ }^{9}$ 
Opstilling 3.3.2. Procent af de 18-74-årige, der inden for det seneste år har oplevet sig udsat for tyveri og/eller hoervaerk og/eller vold og/eller alvorlige trusler (»kriminalitet«) i Grønland, 1995/96 og 2013/14, og i Danmark, 1995/96 og 2013, som har anmeldt det til politiet eller hvor politiet har fået nyt om forholdet på anden vis

\begin{tabular}{lcccc}
\hline & \multicolumn{2}{c}{ GRØNLAND } & \multicolumn{2}{c}{ DANMARK } \\
\cline { 2 - 5 } & $1995 / 96$ & $2013 / 14$ & $1995 / 96$ & 2013 \\
\hline Pct. anmeldt $\gg$ kriminalitet & 49 & 61 & 54 & 51 \\
\hline
\end{tabular}

For en snes år siden var der i Danmark sammenlignet med Grønland en lidt samlet større tendens til, at »kriminalitet«, som man var blevet udsat for, var blevet meldt til politiet, eller at politiet havde fået nys om det på anden vis, jf. opstilling 3.3.2. Fordi »anmeldelsestilbøjeligheden« siden er steget i Grønland, men ikke i Danmark, forholder det sig omvendt i 2013/14: »Anmeldelsestilbøjeligheden« er større i Grønland. ${ }^{10}$

\subsection{Befolkningen og kriminaliteten}

At den traditionelle kriminallovskriminalitet er faldet de senere år, ser ikke ud til at være bemærket eller har fået gennemslag i, hvordan den grønlandske befolkning opfatter det - tværtimod. Hele 62 pct. var i telefonundersøgelsen af den opfattelse, at kriminaliteten var steget, og hver tredje endog at den var steget meget. Kun 11 pct. mente, den var faldet.

Denne kontrast mellem kriminalitetens faktiske udvikling og befolkningens oplevelse af samme er næppe et særlig grønlandsk fænomen. Når man kigger på forskellige undersøgelser foretaget på forskellige tidspunkter rundt omkring i verden, synes det nærmest at være universelt, at et flertal i befolkningen oplever kriminaliteten som stigende - uanset om dette er tilfældet eller ej. En undersøgelse foretaget i Danmark i 2013 viste, at det var 50 pct., der mente, at der var mere kriminalitet i Danmark end for fem år siden, mens kun 10 pct. mente, at der var mindre (Epinion, 2013) - selv om Danmark i denne periode reelt havde et ganske markant fald i kriminaliteten. Måske er det en del af en bredere konceptuel tendens til at mene, at »verden er af lave«, og at »det var bedre før i tiden«. Generelt synes sådanne opfattelser af livet, samfundet og verden især at være udbredt blandt ældre, og der er da også såvel i Grønland som i Danmark relativt flest ældre, der har en oplevelse af, at kriminaliteten er stigende. Måske det specielt for kriminalitetens vedkommende har sammenhæng med, at det er et område, hvor 
man, især via medierne, erfarer, at der sker noget hele tiden, og at der næsten hver dag er sket noget (helt) nyt.

De grønlændere, der har en korrekt oplevelse af udviklingen, er især at finde blandt dem, der via deres uddannelse, arbejde eller profession har særligt gode muligheder for at vide, hvordan det faktisk forholder sig. I den danske undersøgelse er der relativt flest blandt de højtuddannede, der deler den korrekte opfattelse af, at kriminaliteten har været faldende.

Kriminalitet har ry for at være et område, der optager alle, men dette viser sig langt fra at gøre sig gældende for alle eller tilnærmelsesvis alle grønlændere. I så henseende synes grønlænderne delt i tre nogenlunde lige store grupper: $\mathrm{Ca}$. en tredjedel der i meget høj eller temmelig høj grad følger med i, hvad der i medierne skrives og fortælles om kriminalitet m.v.; en tredjedel der følger en del med og så en tredjedel der kun lidt eller slet ikke følger med i kriminalitetsstoffet.

Det er dog vigtigt at fremhæve, at man godt kan være stærkt optaget af kriminalitetsproblemet mv., selv om man ikke følger så meget med i medierne. Til trods for at det har været tidskrævende, har interessen således været stor for at deltage i de forskellige undersøgelser, der ligger til grund for nærværende rapport, ikke mindst fokusgruppeundersøgelserne. Når filmene har været vist med fiktive retssager om vold og voldtægt for mindre grupper rundt omkring i Grønland har mange, især i de små samfund, siddet yderst på stolen for at følge med, selv om disse film i spændingsniveau ville kunne være blevet udkonkurreret af en hvilken som helst krimi. Det var tydeligt, at filmene rørte ved nogle problemstillinger, som optog mange. Her blev der visualiseret nogle problemer, som man oplevede som tæt på - og som man syntes var store, og som der burde gøres noget (mere) ved. Man kunne genkende de forurettede og/eller de tiltalte i form af egne oplevelser eller fra nogen man kendte - eller fra noget man kendte til var sket og kunne ske igen.

Hele to ud af tre af grønlænderne, 67 pct., mente, at kriminalitet var et meget alvorligt problem for det grønlandske samfund, jf. opstilling 3.4.1. Kriminalitetsproblemet er noget næsten alle har en mening om. Ikke en eneste nægtede at svare på dette spørgsmål, og kun få svarede ved ikke. 22 pct. tilkendegav, at de syntes, at kriminalitet var et temmelig stort problem for det grønlandske samfund, og kun en ud af ti, 10 pct., anså kriminalitetsproblemet for at være et lille problem eller slet ikke noget problem. 
Opstilling 3.4.1. Synes du at kriminalitet er et problem for det grønlandske samfund? Procentfordeling (Telefonundersøgelsen)

\begin{tabular}{lr}
\hline Et meget stort problem & 67 \\
Et temmelig stort problem & 22 \\
Et lille problem & 7 \\
Ikke noget problem & 3 \\
Vil ikke svare & - \\
Ved ikke & 1 \\
\hline I ALT procent & 100 \\
$\mathrm{n}=$ & 696 \\
\hline
\end{tabular}

Til sammenligning kan nævnes, at det ifølge de seneste undersøgelser i Danmark er mindre end hver tredje dansker, der synes, at kriminalitet er et meget alvorligt problem for og i det danske samfund (Justitsministeriet, 2015).

Såvel demografisk som geografisk deles den stærke samfundsmæssige bekymring for kriminaliteten af praktisk talt alle undergrupper i den grønlandske befolkning. Uddannelsesmæssigt er der dog en undtagelse, idet »kun« 45 pct. af dem, der har en lang boglig uddannelse (universitetsuddannelse o.lign.), synes, at kriminalitet er et meget stort problem for det grønlandske samfund.

En anden undtagelse er af geografisk karakter. I Aasiaat er det »kun« 49 pct. af indbyggerne, der synes, at kriminalitet er et meget stort problem. Narsaq er et andet område, hvor der er relativt få (59 pct.). Kontrasten er områderne Qaqortoq, Maniitsoq, Sisimiut og Uummannaq, hvor omkring otte ud af ti vurderer kriminalitetsproblemet som værende meget stort. Nuuk placerer sig med 69 pct. omkring det gennemsnitlige for hele Grønland. Generelt er det relativt set lidt flere i bygderne end i byerne, der anser kriminalitetsproblemet for at være meget stort, 74 pct. overfor 67 pct.

Såvel blandt mænd som blandt kvinder er det et stort flertal, der anser kriminalitetsproblemet for at være meget stort, men flertallet er størst blandt kvinderne (73 over for 62 pct.).

Blandt personer født i Grønland anser 70 pct. kriminalitetsproblemet for meget stort, hvilket er betydeligt flere end blandt personer bosiddende i Grønland, men født i Danmark, hvor det »kun« er lige godt halvdelen, 53 pct. Samme ganske markante forskel gør sig gældende, hvis opdelingen af "grønlændere« og »danskere« foretages ud fra det sprog, som telefoninterviewet er gennemført på (71 over for 52 pct.). 
Man kunne forestille sig, at det ville gøre en forskel, om man i sit daglige virke, eller i det mindste lejlighedsvis, havde berøring med kriminalitetsproblemer med hensyn til, hvor stort man vurderede disse problemer til at være for det grønlandske samfund. Dette viser sig imidlertid i en række henseender ikke at være tilfældet. Der er en svag tendens til, at personer, der arbejder inden for politiet, domstolene eller det sociale system, vurderer problemerne som lidt større, men forskellene er ikke statistisk signifikante. Personer, der ifølge deres egen tilkendegivelse, ved mere om, hvordan domstolene dømmer i kriminalsager, vurderer ikke kriminalitetsproblemets størrelsesorden anderledes end befolkningen i almindelighed. Personer, der en eller flere gange selv har fungeret som dommer, domsmand, anklager og/eller vidne, vurderer heller ikke kriminalitetsproblemets størrelsesorden som anderledes end folk i almindelighed. Derimod vurderer personer, der selv en eller flere gange har været den forurettede i en retssag eller den tiltalte, gennemgående kriminalitetsproblemets som værende mindre stort end andre.

Man kunne også forestille sig, at det spiller en rolle, om man har oplevet kriminaliteten på egen krop som offer. Måske lidt overraskende viser det sig imidlertid, at det ikke gør nogen forskel, om man inden for det seneste år forud for udspørgningstidspunktet har været udsat for tyveri, hærværk, vold og/eller alvorlige trusler om vold. For kvinder viser der sig at være en forholdsvis markant højere andel af dem, der inden for de seneste fem år har været udsat for voldtægt, forsøg på voldtægt eller anden form for sexkrænkelse, der anser kriminalitetsproblemet for meget stort i det grønlandske samfund, end blandt dem der ikke har været udsat. Mænd er, som tidligere nævnt, ikke blevet stillet dette spørgsmål. Til gengæld er både mænd og kvinder blevet stillet spørgsmålet om, hvorvidt de som børn eller unge (under 18 år) er blevet udsat for voldtægt eller anden sexkrænkelse. Her finder man igen en, om end noget afsvækket, tendens til at kvinder, der har været udsat, vurderer kriminalitetsproblemet som større end de ikke-udsatte. For de mandlige udsatte og ikke-udsatte er der ingen forskel.

Personer, der anser kriminalitetsproblemet for meget stort for det grønlandske samfund, har - hvis de er blevet udsat for en forbrydelse - oftere anmeldt det til politiet end andre ofre. Det kan tænkes, at der heri ligger en tilkendegivelse af, at man i særlig grad har et ønske om, at der bliver gjort noget (mere) ved kriminalitetsproblemet og med de kriminelle. Man kan dog ikke se bort fra den mulighed, at det helt eller delvist beror på forskelle i alvorlighedsgrad vedrørende den kriminalitet, man er blevet udsat for.

Det er blevet hævdet, at grønlændere sammenlignet med en række andre befolkningsgrupper, eksempelvis den danske, har en debat- og meningskultur, der 
er temmelig absolut. Enten er man enig eller uenig - og hvis man er enig, så er man meget enig - og hvis man er uenig, så er man meget uenig. Det kunne være noget af forklaringen på, at så mange, som tilfældet er, vurderer kriminalitetsproblemet som meget stort - jævnfør også den nævnte forskel, hvor betydeligt flere af de i Grønland bosiddende grønlændere end danskere vurderer kriminalitetsproblemet som meget stort. Dette er dog spekulation, idet man også skal lægge mærke til, dels at der midt i 1980-erne i Danmark, da man begyndte på den slags målinger, var omkring to ud af tre, der anså kriminalitetsproblemet som værende meget stort (i Danmark), og dels, at der i 2014 er betydeligt flere af de i Grønland bosiddende danskere, der anser kriminalitetsproblemet som værende meget stort $\mathrm{i}$ det grønlandske samfund, end der er danskere bosiddende i Danmark, der anser kriminalitetsproblemet som værende meget stort i det danske samfund.

En lidt beslægtet problemstilling vedrører den mulighed, at den betydelige samfundsmæssige bekymring hos nogen snarere er et udtryk for, at de reagerer, som de tror, det forventes af en samfundsbevidst borger, frem for at det er personligt dybtfølt. Hvis man oplever, at samfundet og omgivelserne fokuserer meget på et problem, og giver det stor opmærksomhed, kan det være vanskeligt personligt helt eller delvist at afvise det som et problem. Man kan i så fald opleve sig set på som ansvarsløs og mere eller mindre ligeglad med sine medmennesker. Hvis holdningerne var dybtfølte, skulle vi forvente, at de ikke i samme grad, som hvis dette ikke er tilfældet, ville lade sig påvirke af den kontekst, man svarer i. Vi finder imidlertid, at svarene i en vis udstrækning synes at være påvirket dels af, om man var alene, da man blev telefoninterviewet, og dels af interviewerens køn.

Eksempelvis var der blandt de, der var alene, da de blev telefoninterviewet, 65 pct. der angav, at de syntes, kriminalitetsproblemet var meget stort i det grønlandske samfund, mens dette var tilfældet for 70 pct. af dem, hvor det var usikkert, om der var andre tilstede - og 75 pct. af dem, der ikke var alene. Dette kunne godt tyde på, at der gør sig en vis »forstærkningseffekt $t$ gældende vedrørende holdningen til kriminalitetsproblemets størrelse, når den skal tilkendegives over for andre, eller der i hvert fald er andre tilstede.

Det er helt tilfældigt, om man er blevet interviewet af en mand eller en kvinde. Ikke desto mindre giver dette et statistisk signifikant udslag på, hvor stort man svarer, at kriminalitetsproblemet er. 54 pct. af de, der blev interviewet af en mand, svarede, at de mente, at kriminalitetsproblemet var meget stort, mens det var hele 72 pct. af dem, der blev interviewet af en kvinde. Måske opfordrer en mandlig interviewer ubevidst og utilsigtet mere til et »macho-svar«, hvor svaret tilkendegiver, at man ikke er bange for noget, og en kvindelig interviewer til et »omsorgs-svar«, hvor man viser, at man er parat til at se problemerne i øjnene og 
få gjort noget ved dem? Hvis denne fortolkning har noget på sig, skulle vi bl.a. forvente, at de to ekstremer ville være henholdsvis en mand, der blev interviewet af en mand, og en kvinde, der blev interviewet af en kvinde. Og det er præcis sådan det forholder sig. Blandt de mænd, der blev interviewet af en mand, var der 44 pct., der mente, at kriminalitetsproblemet var stort i det grønlandske samfund, mens det var 76 pct. blandt de kvinder, der blev interviewet af en kvinde. ${ }^{11}$

At mene, at kriminalitet er et stort problem for det grønlandske samfund, betyder ikke nødvendigvis, at man personligt frygter at blive udsat for kriminalitet. Heller ikke det omvendte er nødvendigvis tilfældet: Man kan godt personligt være bange for at blive udsat for kriminalitet, uden at man nødvendigvis mener, at kriminalitet er et stort problem for det grønlandske samfund som sådan. Den samfundsmæssige og den personlige bekymring for kriminalitet er som udgangspunkt to forskellige ting. På engelsk ville man kalde den første for »concern« og den sidstnævnte for »fear«. Det er svært at finde et tilsvarende helt dækkende ord på dansk for »concern«, mens »fear« er frygt, eventuelt angst.

Det viser sig at være hver syvende grønlænder mellem 18 og 74 år - 14 pct. der ofte eller næsten hele tiden i dagligdagen går rundt og tænker på deres personlige risiko for at blive udsat for kriminalitet. Til gengæld var det næsten halvdelen, 48 pct., der aldrig skænkede deres personlige risiko for at blive udsat for kriminalitet en tanke, og tager vi dem med, der sjældent tænker på det, var det tre ud af fire -76 pct.

Den personlige bekymring ligger altså på et langt lavere niveau end den samfundsmæssige bekymring for kriminalitet. 67 pct. syntes, at kriminalitet var et meget stort problem for det grønlandske samfund, mens »kun« 14 pct. hele tiden eller ofte tænkte på deres personlige risiko for at blive udsat. 76 pct. tænkte som nævnt aldrig eller kun sjældent på deres personlige risiko for at blive udsat for kriminalitet, mens »kun« 10 pct. syntes, at kriminalitet ikke var noget problem eller kun et lille problem for det grønlandske samfund.

Blandt svarpersoner, der næsten hele tiden eller ofte bekymrede sig om deres personlige risiko for at blive udsat for kriminalitet, var det den absolutte undtagelse, at man ikke anså kriminaliteten for at være et temmeligt eller meget stort samfundsmæssigt problem. Blandt svarpersoner, der aldrig personligt bekymrede sig for kriminalitetsrisikoen, var det alligevel 84 pct., der anså kriminaliteten for et være et temmeligt eller meget stort problem, og »kun« hver sjette der syntes, at kriminaliteten ikke var noget problem eller kun et lille problem.

Set den anden vej fra var det mindre end hver femte af dem, der syntes, at kriminaliteten var et meget stort samfundsmæssigt problem, som selv ofte eller næsten hele tiden gik rundt og personligt bekymrede sig for at blive udsat. 44 pct. 
tænkte aldrig på det i dagligdagen. For dem, der syntes, at kriminaliteten var et lille eller slet ikke noget problem for det grønlandske samfund, var det undtagelsen, at man var bekymret for selv at blive udsat. Langt de fleste i denne gruppe tænkte aldrig på deres personlige risiko.

Opstilling 3.4.2. Den personlige bekymring for kriminalitet blandt 18-74-årige i Danmark og Grønland, $2014^{*}$

\begin{tabular}{lcc}
\hline Bekymrer sig ... & Grønland & Danmark \\
\hline Næsten hele tiden & 5 & 3 \\
Ofte & 9 & 10 \\
Af og til & 20 & 24 \\
Sjældent & 18 & 39 \\
Aldrig & 48 & 24 \\
Uoplyst & 0 & 0 \\
\hline I ALT & 100 & 100 \\
$\mathrm{n}=$ & 696 & 2.630 \\
\hline
\end{tabular}

* Begge undersøgelser er gennemført i første kvartal 2014.

I opstilling 3.4.2 er det personlige bekymringsniveau med hensyn til kriminalitet i Grønland sammenlignet med Danmark. Til trods for at kriminalitet, der har karakter af personlige overgreb, ligger på et betydeligt højere niveau i Grønland end i Danmark, er bekymringsniveauet ikke højere. Snarere tværtimod. Når man tager den statistiske usikkerhed i betragtning, er der omtrent lige mange, for hvem kriminalitetstruslen ofte eller næsten hele tiden er et problem, men der er i Grønland dobbelt så mange som i Danmark, der aldrig skænker deres personlige risiko for at blive udsat for kriminalitet en tanke.

Umiddelbart kunne man forestille sig, at et af de forhold, der kunne have stor betydning for den personlige frygt for kriminalitet, er, om man selv har været udsat for kriminalitet. Det viser sig da også at gøre en forskel, men den er ikke overvældende stor. 18 pct. af de, der havde været udsat for en eller anden form for ejendoms- eller voldskriminalitet inden for det seneste år, tænkte ofte eller næsten hele tiden på deres risiko for (påny) at blive udsat for kriminalitet, mens det »kun« var 13 pct. blandt dem, der ikke havde været udsat. Overraskende nok er det især ejendomskriminalitet - tyveri og hærværk - der gør en forskel, mens de, der har været udsat for vold eller trusler om vold, ikke var mere frygtsomme, end de der ikke havde været udsat herfor. Om man har været udsat for sexkræn- 
kelser som barn eller ung gør ingen forskel, men blandt kvinder, der har været udsat for tvangssamleje eller forsøg herpå inden for de sidste fem år forud for interviewtidspunktet, var der langt flere - 38 pct. - der tænkte på risikoen for (påny) at blive udsat for kriminalitet, end blandt de kvinder der ikke havde været udsat (14 pct.). Generelt betød det mere for kvinders bekymring end for mænds, om de havde været udsat for kriminalitet - og mere for yngres end ældres.

Det er bemærkelsesværdigt, at der findes en endnu stærkere sammenhæng mellem bekymring for kriminalitet, og hvor meget man følger med i medierne om kriminalitet, end mellem bekymring og personlig udsathed for kriminalitet. Med hensyn til bekymring og medieeksponering skal man være opmærksom på, at sammenhængen kan gå begge veje: Det er tænkeligt, at det at se, høre og læse om kriminalitet i medierne øger bekymringen, men det er også tænkeligt, at de mere bekymrede i højere grad følger med i medieres stof om kriminalitet. Blandt de, der følger meget eller temmelig meget med i mediernes stof om kriminalitet, er der næsten tre gange så mange, der er bekymrede for deres personlige risiko for at blive udsat for kriminalitet - 23 pct. - sammenlignet med dem, der ikke følger så meget med eller slet ikke følger med, 8 pct. Blandt de, der følger »en del« med, var der 11 pct. bekymrede, så det er især den stærke medieeksponering for kriminalitet, der har sammenhæng med et relativ højt bekymringsniveau.

Det selv at have været udsat for kriminalitet betyder ikke, at man følger mere med i mediernes stof om kriminalitet. Der er ingen forskel i så henseende mellem ofre og ikke-ofre. Den mulige angstfremkaldende reaktion på medieeksponering for kriminalitet synes især at gøre sig gældende for personer, der ikke selv har været udsat. Hver fjerde, 25 pct., der ikke selv havde været udsat, tænkte ofte eller næsten hele tiden på deres personlige risiko for at blive udsat, over for »kun« 7 pct. af de ikke udsatte som ikke fulgte mediestof om kriminalitet. For de, der fulgte meget med i stof om kriminalitet, syntes det personligt at blive udsat for kriminalitet nærmest at have en »afdramatiserende« virkning, idet der her blandt ofrene »kun« var 14 pct., der var bange, over for 19 pct. af dem, der ikke havde været udsat.

Man kan komme tæt på kriminaliteten på andre måder end ved at blive udsat for eller lade sig eksponere for den i medierne, bl.a. via overværelse af eller deltagelse $\mathrm{i}$ en retssag $\mathrm{i}$ en eller flere af de forskellige roller, der findes her. Blandt personer, der har fungeret som dommere eller domsmænd i en kriminalsag, var der meget få, der personligt var bekymrede for at blive udsat for kriminalitet, sammenholdt med dem, der ikke havde været dommere eller domsmænd, mens tendensen var den omvendte for folk, der havde deltaget som forurettede, tiltalte, 
anklagere, forsvarere og/eller tilhørere. Om man havde været vidne i en retssag eller ej havde ikke sammenhæng med personlig bekymring for kriminaliteten.

I mange lande og i mange undersøgelser har man fundet en tendens til, at der er flere kvinder, der bekymrer sig for deres personlige risiko for at blive udsat for kriminalitet, end mænd - men sådan er det ikke i Grønland. Der var ikke forskel overhovedet. Heller ikke alder gjorde den store forskel. Der var kun en ganske svag tendens til, at den personlige bekymring øgedes med alderen. Endvidere gjorde det ingen forskel, om man var født i Grønland eller ej.

Til gengæld findes der betydelige geografiske forskelle i det personlige bekymringsniveau. I byerne var der næsten dobbelt så mange, der personligt var bekymrede for kriminaliteten (14 pct.) som i bygderne (8 pct.). I Nord- og Østgrønland var der 18 pct., der ofte eller næsten hele tiden tænker på deres personlige risiko for at blive udsat for kriminalitet - over for »kun« 8 pct. i Midtgrønland.

Også med hensyn til den personlige bekymring og angst kunne man forestille sig, at der ville være en »interviewereffekt« - altså at ens villighed til at give udtryk for sin eventuelle angst ville være afhængig af, hvem der spørger, og den situation man udspørges i. Hvad end forklaringen er, findes der en forholdsvis markant tendens til, at flere giver udtryk for personlig bekymring for kriminalitet, når de interviewes af en ung, end når de interviewes af en lidt ældre person. Tillige er der lidt flere, der giver udtryk for personlig bekymring, når de ikke har været alene under interviewet. Måske har nogen oplevet en forventning om, »at kriminalitet er et stort problem, og det bør man selvfølgelig være personligt bekymret for« og svaret herefter, uden at det dækker over en reel personlig bekymring?

Man kunne have en forventning om, at de personligt bekymrede i højere grad end de ikke-bekymrede ville have en oplevelse af, at kriminaliteten var stigende og omvendt. Overraskende nok viste dette sig ikke at være tilfældet. Der var ingen eller i hvert fald kun en meget svag sammenhæng mellem oplevelsen af kriminalitetens udvikling i Grønland på den ene side og den personlige bekymring for kriminaliteten på den anden.

\section{Reaktioner på kriminalitet - formålet}

Alle er enige om, at samfundet skal reagere på kriminalitet, eller i hvert fald den del af kriminaliteten som det kriminalretlige system får kendskab til - men hvordan, og med hvilket formål? Traditionelt sondres der mellem tre forskellige mulige formål med at foranstalte/straffe: 
1) Det repressive formål, der tidsmæssigt er bagudvendt og rettet mod (til) alle andre end den person, der foranstaltes/straffes. Formålet er her via en eller anden form for tilsigtet lidelse for den dømte at opnå en følelse af, at retfærdighed er sket fyldest. Med et mindre smigrende begreb kan man også sige, at alle vi andre herigennem forsøger at opnå en eller anden form for »hævn«. Endvidere kan man tillige udvide det til at inkludere en forhåbning om, at den dømte via sin dom og under foranstaltningens/straffen vil »sone« sin brøde, dvs. gennem en eller anden form for lidelsesproces angre og fortryde.

2) Det generalpræventive eller almenpræventive er også et formål, som retter sig mod at give en gevinst for alle, men som tidsmæssigt sigter på fremtiden. Ønsket er her, at foranstaltningen/straffen skal tjene som et afskrækkende eksempel, der afholder folk fra at begå en tilsvarende forbrydelse, eller forbrydelser i det hele taget. Dette formål er altså af nyttemæssig karakter. Foranstaltningssystemet/straffesystemet og dets udformning og anvendelse i praksis har her som formål at mindske kriminaliteten i samfundet.

3) Det specialpræventive eller individualpræventive formål er ligeledes af nyttemæssig karakter og retter sig mod at opnå en fremtidig gevinst. Formålet er her at foranstaltningen/straffen skal bidrage til at mindske risikoen for, at den dømte påny begår kriminalitet. Det kan enten ske gennem forsøg på uskadeliggørelse (f.eks. ved at forhindre den dømtes eventuelle kriminalitet i samfundet $\mathrm{i}$ en periode gennem indespærring el.lign.), og/eller forsøg på afskrækkelse og/eller forsøg på resocialisering (hjælp, social støtte, behandling mv.).

Det er ikke tilfældigt, at det i Grønland hedder en kriminallov og ikke, som bl.a. i Danmark, en straffelov, og at de mulige reaktioner benævnes foranstaltninger, og ikke straffe. Det afspejler på det principielle plan mindre vægtning af det repressive og det almenpræventive formål i det, man ønsker at opnå ved at reagere på kriminalitet, og en større vægtning af det individualpræventive. Det er også ofte blevet omtalt og diskuteret som gerningsprincippet over for gerningspersonprincippet, altså om det er beskaffenheden af den kriminelle handling, der lægges til grund for at vurdere, hvad der skal ske, eller om det er personen og personens situation.

Der findes en interessant diskussion af, hvorfor gerningspersonprincippet fik en så principielt fremtrædende betydning, som tilfældet var, da man i 1954 for første gang fik en formaliseret kriminallov i Grønland. ${ }^{12}$ Var det en kodificering af praksis, som den allerede var, forankret i ikke blot, hvordan de grønlandske retsmyndigheder samt den grønlandske befolkning synes det skulle være, jf. den såkaldte juridiske ekspedition, ${ }^{13}$ eller var det et ønske om, hvordan det bur- 
de/kunne være hos de jurister, der forberedte og udarbejdede kriminalloven, præget som de måske var af de behandlingstanker mv., der på daværende tidspunkt var i fokus såvel indenfor kriminologien som strafferetstænkningen i mange af de europæiske straffesystemer (jf. bl.a. Breinholdt Larsen, 1999)? Man skal erindre sig, at også den danske straffelov af 1930, som stadig er den gældende, var præget af individualpræventive elementer. ${ }^{14}$

Allerede på et tidligt tidspunkt få år efter 1954-lovens ikrafttrædelse, kunne man konstatere, at det under alle omstændigheder ikke helt blev, som det var tænkt og tilsigtet. De første egentlige undersøgelser af 1954-lovens virke blev gennemført i 1960-erne, og her konstaterede man, at loven langt fra havde fungeret efter hensigten. Foranstaltningerne blev i langt højere grad, end det havde været tilsigtet, fastsat med udgangspunkt i gerningens beskaffenhed. Domme, der var udformet med henblik på resocialisering af gerningspersonen, var forholdsvis sjældne, og specielt var der en meget udstrakt brug af bøder (jf. bl.a. Therbild, 1965). Tre mulige forklaringer på denne udvikling har været fremsat. Den ene går ud på, jf. ovenstående, at hverken retsmyndigheder eller befolkning delte det individualpræventive udgangspunkt for at reagere på kriminalitet. Den anden peger på, at det kan skyldes, at retsmyndighederne ikke havde de praktiske muligheder for at iværksætte de vigtigste af lovens resocialiserende foranstaltninger, som eksempelvis dom til uddannelse (Goldschmidt, 1963). Den tredje mulighed, der er blevet peget på, er det grønlandske samfunds stigende modernisering og urbanisering i perioden, som også var fulgt at stigende kriminalitet. Fra at være baseret på primærgrupper, hvor medlemmerne havde et intimt kendskab til hinanden, var det grønlandske samfund nu i stigende grad præget af sekundær-relationer. Goldschmidt, der var en af den juridiske ekspeditions tre medlemmer, antog, at ...

")... the more urbanized these Greenland communities became, coinciding with emergence of secondary relations, the more the original pattern of resocialization tended to weaken. The idea behind this assumption is that the less people identify with all members of their community, and consequently with local criminals, the more hostile they will be toward them « (Goldschmidt, 1973).

Goldschmidt mente, at det med denne samfundsudvikling var blevet sværere og sværere at få befolkningen til at tage sig af de domfældte, og Goldschmidt mente endvidere, at det grønlandske folk i almindelighed følte sig fremmedgjorte og magtesløse over for den hurtige samfundsudvikling, der hovedsageligt var styret af danske eksperter. Dette førte til apati og passivitet, der gav sig udslag i et skift i 
holdning til lovovertrædere fra aktiv til passiv tolerance (her citeret efter Breinholt Larsen, 1999). ${ }^{15}$

Hvor om alting er, så har den seneste kriminallov, der som tidligere nævnt trådte i kraft i 2010, betydet (endnu) en vis nedgradering af gerningspersonprincippet og en vis opgradering af gerningsprincippet, ikke mindst på det principielle plan. Dog forholder det sig - formentlig - stadig sådan, at gerningspersonprincippet har en mere fremtrædende vægt end f.eks. i det danske strafferetlige system. ${ }^{16}$ I den nuværende kriminallov for Grønland hedder det i § 121:

Ved valget af foranstaltninger skal der tages hensyn til

1) Lovovertrædelsens grovhed, herunder samfundets interesse i at modvirke handlinger af den pågældende art, og

2) Gerningsmandens personlige forhold, herunder hvad der skønnes nødvendigt for at afholde den pågældende fra yderligere lovovertrædelser.

Tanken har været, at man nu skulle tage et ligeligt hensyn til handling og person ved valg af foranstaltning.

$\S 121$ i den kriminallov, der trådte i kraft i 2010, afløste $\S 87$ i den hidtil gældende kriminallov - en paragraf der ikke var blevet ændret siden den blev indført i $1954::^{17}$

Afgørelsen skal under fornøden hensyntagen til gerningens beskaffenhed og til samfundets interesse $i$ at modvirke handlinger af den pågældende art, træffes med særligt henblik på gerningsmandens personlighed og på, hvad der efter de foreliggende oplysninger må skønnes at være nødvendigt for at afholde ham fra yderligere lovovertrædelser.

At der stadig, i hvert fald på det principielle plan, skal tages et betydeligt hensyn til personlige forhold afspejles også i selve den seneste kriminallovs opbygning, hvor der som tidligere er en fuldstændig adskillelse mellem, hvad der kriminaliseres, og hvordan der kan foranstaltes. Hvor der i de enkelte paragraffer i den danske straffelov angives, hvordan der kan straffes (eller i det mindste rammer herfor), så har eksempelvis paragrafferne vedrørende drab og vold i Grønland følgende ordlyd:

$\S 86$. For manddrab dømmes den, som dræber en anden.

$\S 88$. For vold dømmes den, som forsætligt beskadiger eller krænker en andens legeme. Det samme gælder den, som uagtsomt tilføjer en anden betydelig skade på legeme eller helbred. 
De mulige foranstaltninger, der beskrives og afgrænses samlet og andetsteds i kriminalloven, har karakter af en »foranstaltningsstige«, hvor den typiske udmåling af foranstaltningen vil starte nedefra, og spørge hvilket »trin« handlingens alvorlighedsgrad tilsiger, og hvor man så dels kan gå »op« eller »ned « i forhold til personlige forhold eller afgøre den præcise udformning af det enkelte »trin«. De mulige foranstaltninger er, nævnt i rækkefølge fra »nederste trin«: Advarsel, Bøde, Betinget anstaltsanbringelse, Tilsyn, Samfundstjeneste, Tilsyn og anstaltsanbringelse og Anstaltsanbringelse. Hertil kommer Forvaring på ubestemt tid, samt særlige hjælpeforanstaltninger over for unge kriminelle og særlige foranstaltninger over for psykisk syge kriminelle.

I overensstemmelse med opdelingen i de tre traditionelle og mulige formål med at foranstalte/straffe, blev der i telefonundersøgelsen i Grønland stillet følgende spørgsmål med følgende svarmuligheder:

Når en person har begået noget kriminelt som f.eks. vold eller tyveri, skal samfundet handle. Synes du at måden at handle på først og fremmest skal være for ...

1) At skræmme andre fra at begå kriminalitet

2) At straffe gerningsmanden ham så han kan mærke at samfundet tager afstand fra hans kriminalitet

3) At hjælpe og støtte gerningsmanden så han ikke gør det igen.

Af opstilling 4.1 kan man se, hvordan svarene fordelte sig. For det første er det bemærkelsesværdigt, at der er meget få, der ikke har villet svare, eller som har svaret »ved ikke«. Det ser ud til at være en problemstilling, som den grønlandske befolkning har en mening om, og en mening som de gerne vil fortælle om.

For det andet viser der sig at være en overvældende majoritet - hele 77 pct. som mener, at en dom først og fremmest skal have det formål at hjælpe og støtte gerningsmanden, så han ikke gør det igen, altså et individualpræventivt formål med vægt på resocialisering. 
Opstilling 4.1. Svarfordeling for følgende spørgsmål blandt 18-74-årige $i$ Grønland og Danmark, 2014 (telefoninterviewundersøgelser):

Når en person har begået noget kriminelt som f.eks. vold eller tyveri, skal samfundet handle. Synes du at måden at handle på først og fremmest skal vare for ...

\begin{tabular}{lcc}
\hline & Grønland & Danmark \\
\hline At skræmme andre fra at begå kriminalitet & 5 & 12 \\
At straffe gerningsmanden så han kan mærke at samfundet tager & & 57 \\
afstand fra hans kriminalitet & 15 & 29 \\
At hjælpe og støtte gerningsmanden så han ikke gør det igen & 77 & 0 \\
Vil ikke svare & 1 & 2 \\
Ved ikke & 1 & 100 \\
\hline I ALT procent & 100 & 976 \\
$\mathrm{n}=$ & 696 &
\end{tabular}

* Undersøgelsen i Grønland er gennemført i første kvartal 2014, i Danmark i juli 2014.

15 pct. mener, at en dom først og fremmest skal have som formål at straffe gerningspersonen, mens kun en ud af hver tyve, 5 pct., synes, at formålet først og fremmest skal være at skræmme andre fra at begå kriminalitet.

Det kan således konkluderes, at gerningspersonprincippet er solidt forankret $\mathrm{i}$ den grønlandske befolknings ønsker og forestillinger om, hvad formålet skal være med at foranstalte/straffe en person.

Ved undersøgelsens gennemførelse blev der ikke fundet eksempler på, at prcecis det samme spørgsmål er stillet i andre lande, men svar på spørgsmål, der minder om det stillede i Grønland, tyder på, at det også efter en international målestok kan være en usædvanligt stor del af befolkningen i Grønland, der peger på resocialisering som det primære formål. ${ }^{18}$ Ansporet af den grønlandske undersøgelse gennemførtes en tilsvarende undersøgelse i Danmark nogle få måneder senere i $2014 .{ }^{19}$ Det tilsvarende spørgsmål blev via Danmarks Statistiks omnibusundersøgelser stillet et repræsentativt udsnit af 18-74-årige i Danmark. Som det kan ses af opstilling 3.1, viste holdningen sig her at være markant forskellig. Selv om der trods alt var 29 pct. af danskerne, der mente, at det primære formål skulle være hjælp og støtte med henblik på at reducere tilbagefald, så var det majoriteten, 57 pct., der mente, at det primære formål skulle være at straffe gerningsmanden, så han kunne mærke, at samfundet tog afstand fra hans kriminalitet. Der var også relativt flere i Danmark, der mente, at det primære formål skulle være at afskrække andre fra at begå kriminalitet. 
Befolkningen i Grønland blev yderligere bedt om at tage stilling til, hvad de syntes var det næst vigtigste. Blandt de, der syntes, at det primære formål var at straffe, var der 83 pct., der syntes, at det næst vigtigste formål skulle være resocialisering. Blandt de, der syntes, at det primære formål var at afskrække andre fra at begå kriminalitet, var der 69 pct., der syntes, at det næst vigtigste formål var resocialisering. Alt i alt betyder det, at 95 pct. af svarpersonerne i Grønland pegede på resocialisering som enten det vigtigste eller næst vigtigste formål. ${ }^{20} 21$

Det kunne være nærliggende at tro, at de, der personligt (for nyligt) havde været udsat for kriminalitet, ville prioritere gengældelse o.lign. højere end andre, men dette viser sig ikke at være tilfældet. Der er kun få, små og statistisk set ubetydelige forskelle mellem de, der har været udsat for kriminalitet, og de der ikke har, med hensyn til, hvad der skal være det vigtigste formål med at foranstalte/straffe. Selv ikke kvinder, der havde været udsat for alvorlig seksualkriminalitet, var mere »hævngerrige« end andre, snarere tværtimod: 88 pct. af de kvinder, der havde været udsat for tvangssamleje eller forsøg herpå inden for de seneste fem år forud for interviewtidspunktet, syntes det primære formål skulle være resocialisering, mens det var 82 pct. af de kvinder, der ikke havde været udsat. ${ }^{22}$

Blandt kvinder som helhed var der lidt flere end blandt mænd som helhed, der syntes, at det primære formål skulle være resocialisering - 82 pct. over for 76 pct. Derimod spillede alder ingen betydende rolle for, hvad man syntes skulle være det primære formål.

De, der syntes, at kriminalitet er et meget stort problem for det grønlandske samfund, og/eller som var meget eller temmelig bange for personligt at blive udsat for kriminalitet, gav oftere end andre udtryk for, at de syntes, at resocialisering burde være det primære formål, og ikke omvendt som man måske umiddelbart kunne forvente. ${ }^{23}$

Der tegner sig et billede af, at det især var i »det traditionelle Grønland «, der var den aller største opslutning til og opbakning bag gerningspersonprincippet: Den relativt lavt uddannede del af befolkningen, der var af grønlandsk afstamning og som boede i bygderne. 89 pct. af dem, der havde det til fælles, at de alene havde gået i folkeskole eller evt. havde taget en meget kort uddannelse; at de var født i Grønland, samt at de boede i en bygd, mente, at resocialisering burde være det primære formål. Det samme mente »kun« 50 pct. af dem, der havde det til fælles, at de havde taget en håndværksmæssig eller boglig uddannelse; at de var født i Danmark, samt at de boede i en by.

Ser man på sammenhængen med de enkelte dimensioner i »det traditionelle Grønland « i forhold til »det ikke-traditionelle Grønland«, er billedet følgende: 88 pct. i bygderne mente, at resocialisering skulle være det primære formål over for 
78 pct. i byerne ( 68 pct. i Nuuk); 83 pct. af dem, der var født i Grønland, over for 56 pct. af dem, der var født i Danmark; 88 pct. af dem der alene havde gået i folkeskole eller alene havde en meget kort uddannelse, over for 72 pct. af dem der havde en håndværksmæssig eller en boglig uddannelse.

Forsøger vi os med en mere findelt geografisk opdeling, bliver tallene meget små, men tendensen er klar. I samtlige områder er det et flertal, der synes, at resocialisering skal være det primære formål, og i mange områder er det mere end 90 pct., der har denne holdning blandt de udspurgte, såsom i Nanortalik, Qasigiannguit, Qeqertarsuaq, Tasiilaq og Illoqqortoormiut.

Blandt svarpersonerne i telefonundersøgelsen indgår kun et lille antal, der selv har været dommere eller domsmænd. Tal baseret herpå skal derfor tolkes med særlig stor forsigtighed. Umiddelbart ser det ud til, at de, der er eller har været dommere/domsmænd, i endnu højere grad end andre går ind for gerningspersonprincippet som det primære. 85 pct. af dem tilkendegav, at hjælp og støtte til en kriminalitetsfri tilværelse burde være det primære, over for 79 pct. af dem, der ikke er eller ikke havde prøvet at være dommere eller domsmænd.

Et tegn på, at den dominerende holdning til, at resocialisering skal være det primære formål med at foranstalte/straffe, er - udover de få »undvigende« svar - at den mening, svarpersonerne er fremkommet med, ikke, eller i hvert fald stort set ikke, har vist sig at være afhængig af, hvem man blev interviewet af, eller de omstændigheder hvorunder man er blevet interviewet. Eksempelvis gør det således ingen forskel, om man har været alene under interviewet eller ej, eller om man af intervieweren er vurderet som svarende åbent og ærligt eller som forsigtig/undvigende. Kun er der en svag tendens til, at kvindelige interviewere lidt oftere har fået svar, der fremhæver hjælp og støtte som det vigtigste, end mandlige interviewere.

Et er, hvad der skal være afgørende for valg af foranstaltning, noget andet hvad man synes bør være sigtet med den enkelte foranstaltning, når denne er blevet pådømt. Derfor blev grønlænderne også stillet over for følgende spørgsmål i telefonundersøgelsen vedrørende specielt anstaltsanbringelse:

Hvis en person efter at have begået kriminalitet dømmes til at opholde sig et stykke tid i en anstalt for domfældte, synes du så, at formålet først og fremmest skal være:

1 at straffe ham så han kan mærke at samfundet tager afstand fra hans kriminalitet

\section{ELLER}

2 at han kan modtage hjælp i form af fx behandling (misbrugsbehandling, psykiatrisk behandling el.lign.) for at få bedre muligheder for at leve uden kriminalitet efter løsladelsen. 
Langt de fleste, 86 pct., syntes, at formålet skulle være at hjælpe, og kun 13 pct. mente, at formålet primært skulle være at straffe (1 pct. uoplyste).

Endelig kunne man spørge - og det har vi gjort - hvordan man synes, der bør reageres over for personer, der ikke følger rammerne og spillereglerne for de enkelte foranstaltninger. Her er det igen anstaltsanbringelse, vi har spurgt ind til.

En af de »afvigelser«, der især har været fokus på i de grønlandske anstalter, er brug af hash. I 2013 blev der ikendt 372 disciplinære foranstaltninger, hvoraf baggrunden for næsten halvdelen - 48 pct. - var besiddelse og indsmugling af hash og rygeredskaber. Nærmeste »konkurrent « var undvigelse og udeblivelse (15 pct.). ${ }^{24}$

Derfor stillede vi følgende spørgsmål:

Rygning af hash forekommer af og til blandt de indsatte i anstalterne for domfældte. Personalet gør, hvad de kan for at forhindre det og tager jævnligt urinprøver for at undersøge, om de indsatte har indtaget hash.

Hvordan bør personalet reagere, hvis de opdager, at den indsatte har røget hash? Bør de ...

1 Give den indsatte en advarsel og understrege, at næste gang bliver reaktionen mere alvorlig

2 Straffe den indsatte med mærkbare indgreb i anstaltsvilkårene allerede første gang

3 Prøve at motivere den indsatte til at holde op med at ryge hash, fx i form af behandling

Praksis er at give de indsatte en mindre disciplinærstraf efterfulgt af en samtale. Det viste sig imidlertid at være hele 62 pct. af befolkningen, der syntes, at reaktionen ikke burde være en straf, men en motiverende samtale og evt. behandling. Herudover ville 13 pct. nøjes med en advarsel. Kun 22 pct. ville straffe den indsatte (3 pct. uoplyste).

Betoningen af hjælp, støtte og bistand viser sig således i alle led af foranstaltningsprocessen som det dominerende hensyn og formål for den altovervejende del af den grønlandske befolkning.

Man er også indstillet på, at der bør anvendes flere midler og ressourcer på resocialisering. Selv når det modsatte »foreslås« i den måde spørgsmålet udformes på, er det mindst halvdelen, der protesterer, og mener, at der i hvert fald ikke skal skæres ned. Efter et lodtrækningsprincip blev den ene halvdel af de telefoninterviewede stillet følgende spørgsmål: »Der bruges alt for mange ressourcer på at hjælpe folk, der er dømt for at have begået kriminalitet, til efterfølgende at kunne leve en normal tilværelse uden kriminalitet $\ll$ ? 50 pct. var uenige heri, 38 pct. var enige (mens 12 pct. hverken var enige eller uenige; evt. uoplyste). Den anden halvdel fik stillet spørgsmålet om det samme på følgende måde: »Der bruges alt for få ressourcer på at hjælpe folk, der er dømt for at have begået kriminalitet, til efterfølgende at kunne leve en normal tilværelse uden kriminalitet«? Formuleret 
på denne måde var det 78 pct., der var enige, mens kun 10 pct. var uenige (og også her var det 12 pct., der hverken var enige eller uenige; evt. uoplyste). Den forskel, der er i, hvordan spørgsmålet besvares, alt efter påstandens ordlyd, tyder dog på, at en del måske nok føler, at der ydes rigeligt, men at det ikke rigtigt er socialt acceptabelt at give udtryk for denne holdning over for en interviewer.

Man kunne spørge, hvad der dybere ligger $i$ at have en individualpræventiv tilgang sammenlignet med at have, hvad vi, for enkelthedens skyld, kan kalde en repressiv tilgang? Hvad er konsekvenserne heraf, som befolkningen ser det? Det har vi kunnet udnytte såvel telefonundersøgelsen og postundersøgelsen som fokusgruppeundersøgelsen til at få et lille indblik i. Den individualpræventive tilgang er forbundet med en større tilbageholdenhed og skepsis over for at anvende anstaltsanbringelse som reaktion på kriminalitet, og en større skepsis over for at anvende lange anstaltstanbringelser, når man ikke synes, at man kan komme uden om at anstaltsanbringe (som ved de aller mest alvorlige forbrydelser). Det indgår endvidere i den individualpræventive tankegang, at de anstalter, det er nødvendigt at have, i praksis bør være »natfængsler«, hvor de indsatte i den vågne tid fortrinsvis og hurtigt efter indsættelsen arbejder eller uddanner sig eller følger en eller anden form behandling ude i lokalsamfundet (eventuelt et andet lokalsamfund end hvor forbrydelsen er begået, hvilket jo er identisk med en slags forvisning), og i det meste af fritiden udnytter lokalsamfundets fritidstilbud og er sammen med, primært, familie. For de ikke særligt alvorlige forbrydelser er de reaktioner, de individualpræventivt orienterede grønlændere forestiller sig, først og fremmest bøder/erstatninger; for de noget mere alvorlige og reelt helt over til de aller mest alvorlige samfundstjeneste og/eller en betinget dom med vilkår. Vilkårene kan typisk være pålæg om ikke at færdes bestemte steder eller med bestemte personer (evt. udvisning til et andet lokalsamfund), vilkår om forskellige former for behandling og vilkår om at følge en bestemt uddannelse mv. Om man som flertallet af grønlændere synes, at gerningspersonprincippet skal være det afgørende element ved valg af foranstaltning såvel som for foranstaltningens gennemførelse, eller som mindretallet synes, at det skal være gerningsprincippet, har interessant nok kun meget begrænset sammenhæng med holdningerne til det læge element i retsplejen. Tendensen går faktisk i retning af, at de individualpræventivt orienterede ønsker en lidt stærke juridificering og professionalisering af dommere og forsvarere, end det aktuelt opleves som værende tilfældet.

\section{Reaktioner på kriminalitet - hvordan?}

Grønlands Domstole er en del af Danmarks Domstole og består af fire kredsretter og Retten i Grønland, der alle behandler sager i 1. instans, samt Grønlands Lands- 
ret, som behandler sager i 2. instans. Som udgangspunkt starter alle sager i Grønland ved en af de fire kredsretter. Siden 2010 har kredsdommerne været fastansatte og på fuld tid. Kredsdommerkandidaterne, der er under uddannelse som kredsdommer, er også fuldtidsansatte. Dommerne i kredsretterne er således uddannede på Retten i Grønlands kredsdommeruddannelse, eller også har de - men det er undtagelsen - en egentlig juridisk uddannelse. Retten i Grønland er en ny domstol, der blev oprettet i forbindelse med den retsreform, der trådte i kraft i 2010. Formålet var bl.a. at gøre kredsretterne uafhængige af landsretten, der tidligere bistod dem med vejledning. Retten i Grønland er placeret i Nuuk, men behandler sager fra hele landet. Retten behandler de sager, som ved lov er henlagt til denne instans som 1. instans, herunder insolvenssager som f.eks. konkurs og gældssanering. Desuden behandler retten sager, der er henvist fra de fire kredsretter. Kredsretterne kan henvise alle sagstyper til Retten i Grønland, hvis de er komplicerede eller principielle og derfor kræver, at dommeren er uddannet jurist (Grønlands Domstole, 2014).

Trods den øgede professionalisering og juridificering er hovedreglen stadig, at en kriminalsag behandles af ikke-jurister: Dommere og forsvarere (bisiddere) har gennemgået kortevarende uddannelser, der i udstrækning ikke svarer til en typisk bacheloruddannelse. Anklageren er en politimand. Eventuelle domsmænd er, nu som før, lægmænd.

\subsection{Dommerne}

Af opstilling 5.1.1 fremgår, baseret på telefonundersøgelsen, den grønlandske befolknings holdning til, at de fleste dommere ikke er jurister.

Opstilling 5.1.1. Svarfordeling for følgende spørgsmål blandt 18-74-årige i Grønland, 2014 (telefonundersøgelsen): Her $i$ Grønland er de fleste kredsdommere ikke-jurister, som har gennemgået en kortvarig dommeruddannelse. Hvad synes du i almindelighed om denne ordning?

Det er OK som det er nu

Det er OK, men de burde uddannes bedre

Det burde i noget højere grad være uddannede jurister 28

Det burde i meget højere grad være uddannede jurister 20

Det burde kun være uddannede jurister, selvom de er dansksprogede $\quad 9$

Vil ikke svare

Ved ikke 
Der er ret få, 15 pct., der synes, at det er OK, som det er nu (i 2014), men endnu færre -9 pct. - der mener, at alle kredsdommere burde være uddannede jurister, selvom de er dansksprogede. Den store gruppe, over halvdelen, mener enten, at det er OK, som det er nu, men at kredsdommerne burde uddannes bedre, og/eller at kredsdommerne i noget højere grad burde være jurister. Det er næppe urimeligt at tolke sidstnævnte svar som et ønske om, at det i givet fald (især) er grønlandske/grønlandsksprogede jurister, der ønskes. Set fra den anden led er det kun godt hver fjerde, 29 pct., der synes, at kredsdommerne udelukkende eller fortrinsvis (»i meget højere grad «) burde være uddannede jurister. Der er altså en ganske udbredt forståelse for og ønske om, at de fleste kredsdommere ikke rekrutteres fra de juridiske uddannelser på universiteterne, men fra den almindelige befolkning.

Det er interessant, hvad de, der selv har været udsat for kriminalitet og i bredere forstand de, der deltager eller har deltaget $i$ en eller anden funktion ved en domstol, synes i forhold til andre.

Holdningen til kredsdommernes rekruttering og baggrund fordeler sig ikke anderledes blandt de, der personligt en eller flere gange har haft rollen som forurettet i en retssag, sammenlignet med dem der ikke har. Tilsvarende er der ikke betydelige forskelle mellem svarpersoner, der inden for det seneste år har været udsat for tyveri, hærværk, vold og/eller trusler om vold, og dem der ikke har. Blandt kvinder, der inden for de seneste fem år forud for interviewtidspunktet har været udsat for sexkrænkelser, er der derimod en tendens til i noget eller meget højere grad at ønske sig uddannede jurister blandt kredsdommerne, sammenlignet med dem der ikke har været udsat, men der er ikke flere der mener, at det kun bør være jurister. $^{25}$

Holdningen til kredsdommernes baggrund mv. blandt tiltalte fordeler sig på tilsvarende måde som holdningen blandt forurettede - dvs. at der ikke er forskel i forhold til den øvrige del af befolkningen.

I alt er der ud af de 688 personer, der har svaret på spørgsmålet, 46 der er eller som tidligere selv har prøvet at være dommer eller domsmand. Opstilling 4.1.2 viser, hvordan holdningen fordeler sig i denne gruppe sammenlignet med de 642, der ikke har prøvet at være dommer eller domsmand. ${ }^{26}$ 
Opstilling 5.1.2. Holdningen til kredsdommernes baggrund og uddannelse blandt personer, der er eller har varet dommere eller domsmand, og blandt personer der ikke har det. Telefonundersøgelsen. Procentfordeling*

\begin{tabular}{lccr}
\hline & \multicolumn{2}{c}{$\begin{array}{c}\text { Har været dommer/ } \\
\text { domsmand? }\end{array}$} & ALLE \\
\cline { 2 - 4 } & JA & NEJ \\
\hline Det er ok som det er nu & 28 & 15 & 16 \\
Det er ok, men de burde uddannes bedre & 35 & 27 & 27 \\
De burde i noget højere grad være uddannede jurister & 15 & 28 & 28 \\
De burde i meget højere grad være uddannede jurister & 20 & 20 & 20 \\
De burde kun være uddannede jurister, selvom de er & & & \\
dansksprogede & 2 & 10 & 9 \\
\hline I ALT & 100 & 642 & 688 \\
n $=$ & 46 & & 100 \\
\hline
\end{tabular}

* Uoplyste er ikke medtaget i fordelingerne. Der er, som det fremgår af figur 4.1.1, kun ganske få uoplyste.

Blandt dommerne/domsmændene er der et stort flertal, 63 pct., der synes, at det er OK, som det er nu, eventuelt at kredsdommerne burde uddannes noget bedre, mens stort set ingen -2 pct. - synes, at det udelukkende burde være uddannede jurister. Blandt de, der ikke selv er og aldrig har været dommere eller domsmænd, er de tilsvarende procenter henholdsvis 42 og 10.

Jo større problem, man synes kriminalitet er for det grønlandske samfund, og/eller jo mere man personligt frygter at bliver udsat for kriminalitet, desto stærkere tendens til at ønske mere uddannelse for kredsdommerne og flere jurister. Igen er der dog selv blandt de, der anser kriminaliteten for et meget stort problem for det grønlandske samfund, og/eller som selv er meget ængstelige for at blive udsat for kriminalitet, kun en lille gruppe der synes, at kredsdommerne alle burde være uddannede jurister.

Holdningen til kredsdommernes uddannelse mv. fordeler sig ensartet for mænd og kvinder, og også for svarpersoner født i Grønland sammenlignet med svarpersoner født i Danmark. De yngre har en tendens til i noget højere grad end de ældre at være stemt for mere uddannelse og flere jurister. Det samme gør sig gældende for svarpersoner bosiddende i byerne sammenholdt med svarpersoner bosiddende i bygder. ${ }^{27}$ 


\subsection{Forsvarerne}

Som nævnt er det som udgangspunkt fortsat en lægperson, der fungerer som forsvarer (bisidder) for tiltalte i en kriminalsag. Efter reformen i 2010 styrkede man dog forsvareren ved, at forsvarerens rolle blev præciseret og udstrakt til også at gælde forud for tiltalerejsning. Det blev ligeledes et krav, at en forsvarer skal gennemgå en form for forsvareruddannelse for at kunne blive autoriseret som forsvarer. I sager af alvorlig karakter fik retten tillige mulighed for at beskikke en advokat som forsvarer for den tiltalte eller som rådgiver for den ikke juridisk uddannede forsvarer. I den forbindelse blev der indført en telefonrådgivning, som de autoriserede forsvarere kan benytte. Der findes fortsat kun meget få advokater i Grønland.

Af opstilling 5.2.1 kan man se, hvordan den grønlandske befolkning forholder sig til, at de fleste forsvarere er ikke-jurister. Fordelingen ligner næsten til forveksling fordelingen af holdningerne til kredsdommerne uddannelse mv., og der er da også en meget stærk sammenhæng mellem holdningen til disse to forhold. Synes man, at det er $\mathrm{OK}$ med kredsdommerne, som det er nu, så synes man også, det er OK med forsvarerne, som det er nu. Synes man, at kredsdommerne alle skulle være uddannede jurister, selvom de er dansksprogede, så synes langt de fleste også, at forsvarerne alle burde være uddannede jurister, også selvom de er dansksprogede.

\section{Opstilling 5.2.1. Svarfordeling for følgende spørgsmål blandt 18-74-årige}

$i$ Grønland, 2014 (telefonundersøgelsen): Også de fleste forsvarere er ikkejurister. Disse forsvarere har gennemgået et korterevarende kursus.

Hvad synes du i almindelighed om denne ordning?

Det er OK som det er nu

Det er OK, men de burde uddannes bedre

Det burde i noget højere grad være uddannede jurister

Det burde i meget højere grad være uddannede jurister

Det burde kun være uddannede jurister, selvom de er dansksprogede

Vil ikke svare

Ved ikke 
Ser man endvidere på de svarpersoner, der selv er eller har været forsvarer - det er i alt kun 16 svarpersoner, så talmaterialet er særdeles usikkert på dette punkt finder vi en klar tendens til, at de i højere grad end andre synes, det er OK, som det er nu eller »blot« skal uddannes bedre, og at det i hvert fald ikke kun skal være jurister. Tendensen og proportionerne er helt tilsvarende dem vi så for dommernes vedkommende.

For de svarpersoner, der selv er eller har været anklagere i en eller flere retssager, finder vi måske ikke helt overraskende tendenser, der går i modsat retning, såvel vedrørende holdningen til kredsdommere som holdningen til forsvarere. 45 pct. af anklagerne synes, at kredsdommerne i meget højere grad burde være jurister, eventuelt at det kun skulle være jurister, over for 30 pct. af de svarpersoner, der ikke har været anklagere. 48 pct. af anklagerne synes, at forsvarerne i meget højere grad burde være jurister, eventuelt at de kun skulle være jurister, over for 28 pct. af de svarpersoner, der ikke har været anklagere. Man bemærker sig dog, at det selv blandt anklagerne trods alt er et, om end knebent, mindretal, der ønsker sig, at kredsdommere/forsvarere i meget højere grad eller udelukkende burde være jurister.

\section{Reaktioner på kriminalitet - hvilke?}

Retsfølelse er ikke noget entydigt begreb, men den mest udbredte brug af begrebet vedrører spørgsmålet om, hvor strengt eller hårdt, befolkningen på det generelle plan synes, at der skal straffes/foranstaltes over for kriminalitet. Det drejer sig om punitivitet. ${ }^{28}$ Ofte omtales dette også som den »generelle retsfølelse« eller den »uinformerede retsfølelse«.

\subsection{Hvor streng skal man vare?}

På et spørgsmål om, hvorvidt man syntes, at de foranstaltninger, der idømmes i Grønland gennemgående er passende, for strenge eller for milde - som man roligt kan udnævne til at være det klassiske retsfølelsesspørgsmål - viste det sig at være flertallet, 62 pct., der syntes, at de gennemgående var for milde; 24 pct. syntes, at de var passende, og 3 pct. at de var for strenge (jf. opstilling 6.1.1). Der er på dette spørgsmål relativt mange ubesvarede, 11 pct.

Et tilsvarende spørgsmål er blevest stillet i rigtig mange undersøgelser, i rigtig mange lande, og det generelle billede er - indtil videre - at der altid er et flertal, der synes, at foranstaltningerne/straffene gennemgående er for milde, uanset hvordan straffeniveauet rent faktisk er. På denne baggrund er der således ikke noget specielt overraskende i, at der også i Grønland er et flertal, der har denne holdning på det generelle plan. 
Opstilling 6.1.1. Holdning til, om man gennemgående synes at straffenel foranstaltningerne er passende, for strenge eller for milde blandt 18-74-årige i Danmark (december 2013) og Grønland (første kvartal 2014)

\begin{tabular}{lcc}
\hline Straffene/foranstaltningerne er ... & Grønland & Danmark \\
\hline Passende & 24 & 30 \\
For strenge & 3 & 2 \\
For milde & 62 & 63 \\
Uoplyst & 11 & 5 \\
\hline I ALT & 100 & 100 \\
$\mathrm{n}=$ & 696 & 884 \\
\hline
\end{tabular}

Faktisk er de 62 pct., der synes, at straffene er for milde, som en målestok for punitivitet i den lave ende internationalt set - ligesom i Danmark, hvor det i en måling omkring samme tidspunkt som i Grønland var 63 pct., der havde denne holdning, jf. opstilling 6.1.1. I den nordiske retsbevidsthedsundersøgelse fra 2009-10, var der således færre i Danmark end i de øvrige nordiske lande, der ønskede strengere straffe. Som et led i de såkaldte European Social Survey's blev repræsentative udsnit af befolkningerne (15 år og opefter) i 25 europæiske lande i 2010 bl.a. stillet et spørgsmål om, hvorvidt man var enige i, at de, der overtræder loven, bør straffes langt (min fremhævelse) hårdere, end de bliver i dag. Vurderet ud fra svarene på dette spørgsmål placerede danskerne sig som de mindst punitivt indstillede overhovedet. 45 pct. af danskerne var enige, over for bl.a. 55 pct. af svenskerne, 58 pct. af nordmændene og 76 pct. af finnerne (jf. bl.a. Kyvsgaard \& Boesen Pedersen, 2012). Danmark var det eneste land, hvor det var under halvdelen af befolkningen, der syntes, at der burde straffes langt hårdere.

Der er som ved vurderingen af kriminaliteten som samfundsmæssigt problem tendenser, der kunne tyde på, at nogle mere har svaret, som de har troet, det forventes af dem, end i overensstemmelse med deres egne personlige følelser vedrørende dette emne (eller mangel herpå = ved-ikke). Når der har været andre tilstede under interviewet, er det 70 pct., der har svaret, at de syntes foranstaltningerne gennemgående var for milde, mens det »kun « var 61 pct., når der var andre tilstede. Hvor intervieweren har vurderet svarpersonen til at være lukket og svare undvigende, er det 72 pct., der har svaret, at de syntes foranstaltningerne var for milde, men »kun« 61 pct., når de er blevet vurderet til at være åbne og svare ærligt. Endelig er det 71 pct. af dem, interviewerne har vurderet til at have travlt, og som gerne ville have interviewet overstået hurtigst muligt, der har svaret, at de fandt 
foranstaltningerne for milde, over for $61 \mathrm{pct}$. af dem, der vurderes til at give sig god tid. Disse tendenser synes dog ikke at være stærkere, end at der stadig er et flertal af den grønlandske befolkning, der på det generelle plan mener, at foranstaltningerne gennemgående er for milde - men en del synes altså at ligge under for et forventningspres om at vise sig »hård «. Grønlænderne er også i telefonundersøgelsen blevet bedt om at tage stilling til, hvorvidt de var enige eller uenige $i$ følgende påstand: Samfundet bør reagere langt ... end i dag mod voldsforbrydere. Efter et tilfældighedsprincip er prikkerne $i$ halvdelen af interviewene erstattet med »hårdere«, og i den anden halvdel med »mildere«. Forelagt, at man burde reagere »hårdere«, var der hele 87 pct., der var enige heri, men forelagt at man burde reagere »mildere«, var det »kun « 58 pct., der var uenige.

Når den holdning, der forsøges aflæst via spørgsmålet om, hvorvidt foranstaltningerne er for milde, kaldes for den »uinformerede retsfølelse«, skyldes det dels, at spørgsmålet er meget generelt formuleret (»kriminalitet«, »foranstaltninger «, »for milde« osv.), og dels at vi af andre dele af undersøgelsen kan se, at den foreliggende viden i befolkningen om, hvordan der faktisk foranstaltes og disse foranstaltningers indhold, gennemgående ligger på et relativt, for ikke at sige meget lavt, niveau - som i så mange andre samfund.

Det har derfor en helt særlig interesse at se på, om holdningen til foranstaltningernes strenghed har sammenhæng med, hvad man faktisk ved om, hvordan der foranstaltes.

Opstilling 6.1.2. Procent der synes, at foranstaltningerne gennemgående er for milde set i forhold til svarpersonernes uddannelse. Telefonundersøgelsen

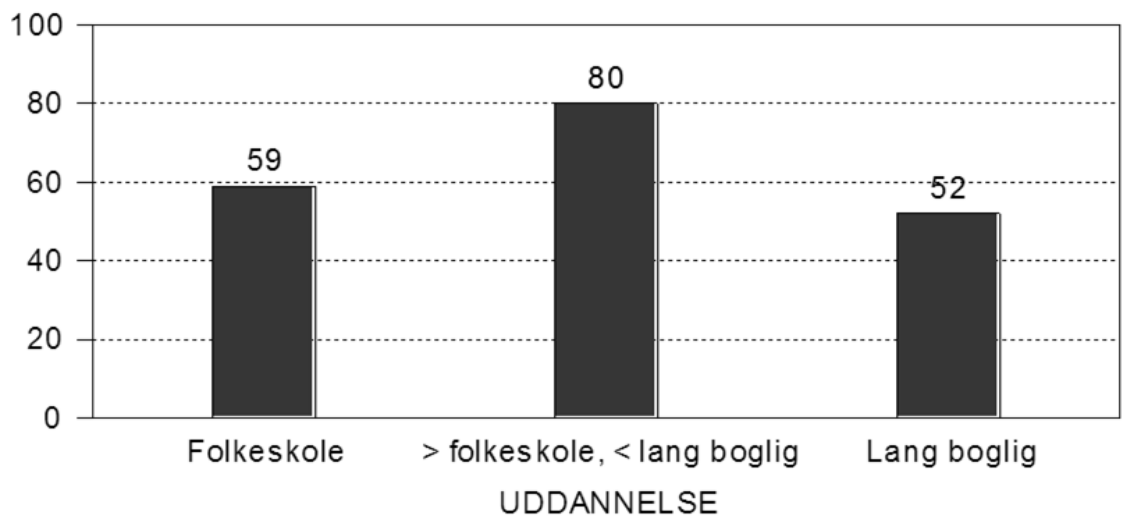


Vi ved, at uddannelse har en vis sammenhæng med, hvor meget mennesker i almindelighed og gennemsnitligt ved om kriminalitet og retsforhold. Af opstilling 6.1.2 fremgår det, at det blandt svarpersoner med lang boglig uddannelse »kun « er lige godt halvdelen, 52 pct., der synes, at foranstaltningerne gennemgående er for milde. Blandt andet i de i Danmark gennemførte undersøgelser finder man, at jo længere uddannelse, man har, desto færre synes, at straffene er for milde. På den baggrund er det ikke overraskende, at det også i Grønland er blandt de længst uddannede, at der er færrest, men i Grønland er der ikke nogen lineær sammenhæng mellem holdningen til foranstaltningernes grad af strenghed og uddannelse. I Grønland er det blandt svarpersoner med den relativt korteste uddannelse (folkeskole), man finder det næstlaveste niveau (59 pct.) for den holdning, at foranstaltningerne gennemgående er for milde, mens det $\mathrm{i}$ hele mellemgruppen uddannelsesmæssigt set er langt flere, 80 pct.

Svarpersonerne er blevet spurgt, om de efter deres egen opfattelse vidste mere eller mindre end gennemsnittet om, hvordan man dømmer i Grønland, og opstilling 6.1.3 viser, hvordan denne vurdering af egen viden hænger sammen med, hvad man synes om foranstaltningerne.

Jo større man vurderer sin egen viden om, hvordan der dømmes i Grønland, som værende, i desto mindre grad vurderer man foranstaltningerne som gennemgående værende for milde. Således er det »kun« lige godt 52 pct. af dem, der vurderer, at de ved en hel del mere end gennemsnittet om, hvordan der dømmes i Grønland, der synes, at foranstaltningerne gennemgående er for milde, mens det er 63 pct. blandt dem, der vurderer deres viden som gennemsnitlig eller ringere end gennemsnittet. ${ }^{29}$

Der kan være forskellige grunde til, at nogle mener at vide mere om, hvordan der dømmes, end andre. En af de vigtigste faktorer er utvivlsomt, om man er eller har været involveret $\mathrm{i}$ det strafferetlige system på en eller flere måder.

Det er dog ikke kun mere viden over for mindre viden, der er indholdet, når vi sammenligner retsfølelsen hos dem, der i forskellige funktioner deltager eller har deltaget i den kriminalretlige proces (retsmøder) med dem, der ikke har. Vigtig her er også den konkrete funktion, der er tale om, og at det ikke er tilfældigt, hvem der (især) deltager og har deltaget i de enkelte funktioner.

Det viser sig, at det ikke gør nogen afgørende forskel med hensyn til retsfølelsen, om man har været tilhører i et retsmøde eller ej, og ej heller om man har været vidne. Mere overraskende kan det være, at det heller ikke gør nogen forskel i retsfølelsen, om man har været forurettet eller $\mathrm{ej}^{30}$ - og heller ikke om man har været tiltalt eller ikke har været tiltalt. 
Opstilling 6.1.3. Procent der synes, at foranstaltningerne gennemgående er for milde set i forhold til svarpersonernes uddannelse. Telefonundersøgelsen

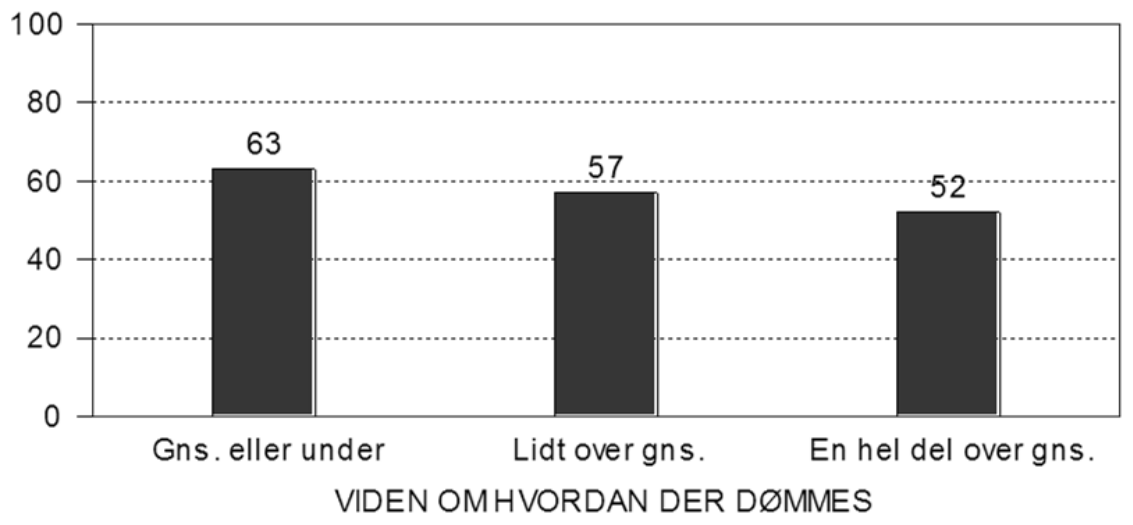

Ser vi derimod på de mere faste positioner i retsprocessen, forholder det sig anderledes. Blandt de, der er eller har været dommere/domsmænd, er der »kun« 52 pct., der synes, at foranstaltningerne gennemgående er for milde, mens det er 63 pct. blandt dem, der ikke har været det. Lidt svagere, men dog samme tendens, findes for dem, der er eller har været forsvarere (56 pct.), sammenlignet med dem der ikke har været det - 62 pct. - men især her skal man huske, at der kun er ganske få forsvarere blandt svarpersonerne, og dermed stor usikkerhed om tallene. Der er heller ikke mange anklagere blandt svarpersonerne, men umiddelbart ser det ud til, at tendensen for dem går i den modsatte retning. Blandt de, der er eller har været anklagere, er der 76 pct., der synes, at foranstaltningerne gennemgående er for milde, over for 61 pct. af ikke-anklagere.

Flere af disse tendenser underbygges yderligere, når retsfølelsen ses i forhold til, om svarpersonerne i deres daglige beskæftigelse, eller i et bijob eller i fritiden, er i berøring med kriminalitet og det kriminalretlige system.

Blandt de personer, der i det daglige har beskæftigelse ved domstolene, er det kun 29 pct., der synes, at foranstaltningerne gennemgående er for milde, og det store flertal som synes, at det er passende, som det er nu. Blandt personer, der i det daglige er beskæftiget ved politiet, er det derimod 83 pct., der synes, at foranstaltningerne gennemgående er for milde. Der er så få af svarpersonerne, der i det daglige er beskæftiget i kriminalforsorgen, at der ikke er grundlag for at vurdere tendensen her. Måske ville man ikke umiddelbart forvente det, men blandt svarpersoner, der i det daglige er i berøring med kriminalitet og det kriminalretlige 
system gennem arbejde i det sociale system, arbejde med behandling mv., er der lidt flere (69 pct.), der synes, at foranstaltningerne gennemgående er for milde, end blandt dem der slet ikke har berøring med kriminalitet mv. i deres daglige beskæftigelse (61 pct.).

Ofte, bl.a. i Danmark, finder man en tendens til, at kvinder på det generelle plan gennemgående er lidt strengere end mænd, ${ }^{31}$ men det er ikke tilfældet i Grønland. Der er forholdsmæssigt lige mange mænd og kvinder, der synes, at foranstaltningerne gennemgående er for milde. Heller ikke alder spiller nogen betydende rolle for, hvad man mener om foranstaltningernes strenghed.

I det hele taget synes almindelige baggrundsfaktorer (bortset fra uddannelse) kun at have ringe eller ingen sammenhæng med holdningen til foranstaltningernes strenghed. Personer født i Grønland er gennemgående lidt »strengere« end personer født i Danmark, men der er ikke forskel i holdningen blandt de (primært) grønlandsk talende og blandt de (primært) dansk talende. I bygderne er man gennemgående lidt »strengere« end i byerne, men forskellen er ikke stor.

Hvordan man skal fortolke, og hvilken betydning man kan eller skal lægge i, at retsfølelsen for de fleste menneskers vedkommende, uanset hvordan straffeniveauet faktisk er, ønsker strengere straffe/foranstaltninger, er et særdeles kompliceret spørgsmål. Bl.a. det forhold, at det synes at være universelt, kunne tyde på, at der primært er tale om et grundlæggende menneskeligt evolutionært forsvar: Når mennesket på en eller anden måde konfronteres med en fare, som man umiddelbart skal reagere på, så reagerer man ved at forsøge at eliminere eller fjerne denne fare, som eksempelvis - i straffetermer - ved vold eller dødsstraf, ved internering som eksempelvis i et fængsel eller ved bortfjernelse/udvisning, fordi det er det mest selvbeskyttende her og nu (Bang Petersen, 2007). Denne tolkning støttes også af, at man i undersøgelsen i Grønland som i mange andre, herunder de tilsvarende danske, finder en tæt sammenhæng mellem ønsket om strengere foranstaltninger/straffe på den ene side, og på den anden side opfattelsen af, at kriminalitet er et meget stort problem for det samfund, man lever i, og at kriminaliteten har været og er (stærkt) stigende - uanset hvor sandt dette så i virkeligheden er. Man føler, at man med hensyn kriminalitet står over for en stor og stadigt stigende og voldsom risiko og trussel. Grundlæggende er det måske ikke lige præcis strengere foranstaltninger/straffe, man ser som løsningen, men det er et led $\mathrm{i}$, at man først og fremmest mener, at der børe gøres noget. Karakteristisk nok, viser ønsket om strengere foranstaltninger/straffe sig i undersøgelser positivt korreleret med ønsket om at gøre næsten hvilket som helst andet med henblik på at mindske kriminaliteten, man foreslår: mere politi, bedre skoler, mere behandling, mere kriminalitetsforebyggende arbejde osv. ${ }^{32}$ Der er altså ingen modstrid på det 
generelle plan mellem at ønske strengere foranstaltninger/straffe og mere kriminalitetsforebyggelse, tværtimod.

Set i dette fortolkningsperspektiv, som et evolutionært forsvar, er det mere bemærkelsesværdigt, at der er 38 pct. af grønlænderne, der ikke umiddelbart har et ønske om strengere foranstaltninger/straffe, end at der er 62 pct., der har det. Det evolutionære forsvar er imidlertid ikke rent biologisk. Det formes og påvirkes af en socialisering i det samfund og den kultur, hvori man befinder sig, hvoraf den vigtigste dimension nok er det menneskesyn, der udvikles. Ser man på andre mennesker som grundlæggende en trussel, man skal være forsigtig overfor, eller møder man tilværelsen med den forestilling, at andre mennesker i almindelighed er til at stole på? Dette klassiske tillidsspørgsmål blev også stillet i telefonundersøgelsen, og der viste sig en klar sammenhæng: Blandt de grønlændere, der gik ind for strengere foranstaltninger/straffe, var det et flertal, der mente, at man, når man havde med andre mennesker at gøre, skulle være meget forsigtige, mens der blandt de grønlændere, der ikke gik ind for strengere straffe/foranstaltninger, var et flertal, der mente, at man $\mathrm{i}$ al almindelighed kunne stole på de fleste andre mennesker.

Hvordan man kan/skal fortolke betydningen af, at et flertal på det generelle plan ønsker strengere foranstaltninger/straffe, har ikke kun akademisk interesse, men også politisk. I den fortolkningsramme, der er givet her, er indbygget den antagelse, at selv om man så skærpede foranstaltningerne/straffene, så ville det ikke nævneværdigt påvirke befolkningens generelle holdning eller tilfredshed. Der ville stadig være et flertal, der ønskede, at de skulle være (endnu) strengere. Det er støttende for denne formodning, at der ikke på samfundsmæssigt niveau synes at være nogen entydig sammenhæng mellem straffeniveau og andelen af befolkningen, der ønsker strengere straffe, og heller ikke over tid. I USA, eksempelvis, har der ganske vist - som i flere andre lande - været en nedgang $\mathrm{i}$ andelen af borgere, der synes, at domstolene dømmer for mildt, men det er stadig et stort flertal der har denne opfattelse til trods for de meget betydelige strafskærpelser, der er sket, og som nu har betydet, er at USA er det land i verden, som har flest indsatte i fængsler i forhold til folketallet. I 1972 var det 74 pct. af amerikanerne, der syntes, at straffene ved deres lokale domstole $\mathrm{i}$ almindelighed var for milde, $\mathrm{i}$ 201264 pct., ${ }^{33}$ og der var i 2012 omkring 4 gange så mange indsatte i forhold til indbyggertallet som i $1972 .{ }^{34}$ I den anlagte fortolkningsramme er det antagelsen, at det vil have større effekt på befolkningens holdning til graden af strenghed i retssystemet at styrke den sociale kapital, der netop typisk defineres og måles ud fra graden af den generelle tillid, som befolkningen har til hinanden (jf. blandt mange andre Putnam, 2001; Tinggaard Svendsen, 2014). Det vigtigste fortolk- 
ningssignal at sende i politisk henseende er, at det drejer sig om den uinformerede retsfølelse. De gennemførte undersøgelser har vist, at befolkningens viden om, hvordan der reelt foranstaltes, er meget lille, og, som det bl.a. fremgår af det følgende, at de forestillinger befolkningen gør sig om, hvordan der foranstaltes, i betydelig grad undervurderer strenghedsgraden. Hvis man politisk ønsker at korrigere strenghedsniveauet i forhold til befolkningens ønsker herom, må referencerammen være befolkningens retsfornuft, hvor den nødvendige viden har været til stede, og hvor der har været tid til at tænke over og bearbejde sagen pr. definition har været til stede, og ikke den spontane uinformerede retsfølelse. ${ }^{35}$

For Grønlands vedkommende kommer hertil, at når hovedformålet med at foranstalte er resocialisering, har spørgsmålet om det generelle syn på foranstaltningernes grad af mildhed eller strenghed hverken samme interesse eller indhold, som når hovedformålet er af repressiv eller af generalpræventiv art. Det grundlæggende valg - dommen - er ikke primært styret af strengheds-parameteren, men nogle kan selvfølgelig være af den opfattelse, at strenghed kan have betydning for resocialisering/recidiv i form af inkapaciterings- eller skræmmeeffekter. Under alle omstændigheder bliver det afgørende og mest interessante spørgsmål, også i kriminalpolitisk henseende, hvordan befolkningen synes, der konkret bør foranstaltes i konkrete sager.

\subsection{Foranstaltninger ved drab}

Den grønlandske befolkning er hverken i postundersøgelsen eller i fokusgruppeundersøgelsen blevet spurgt om, hvordan den synes, der bør foranstaltes i tilfælde af den alvorligste forbrydelse, en konkret drabssag, og drab kan jo dække over meget forskelligartede hændelser. Det er imidlertid det absolutte indtryk, at drab såvel som faktisk forekomst som i forestillingerne er mere entydige i Grønland end i eksempelvis Danmark. For det meste og for de fleste er drab identisk med en hændelse, hvor en person dræber en bekendt eller beslægtet; forud er gået en voldsom alkoholkonsumption, typisk for begge parters vedkommende; stedet er et privat hjem, og det foregår om natten - oftest efter et forudgående værtshusbesøg eller en eller anden form for fest.

Hvor den typiske dom for drab i Danmark lyder på 12 års ubetinget fængsel, er den typiske straf for drab i Grønland 6 års ubetinget anstaltsanbringelse.

De interviewede i telefonundersøgelsen er efter et tilfældighedsprincip blevet opdelt i fire grupper og hver på forskellig måde stillet et spørgsmål om, hvordan de generelt ville dømme i drabssager. Den første af grupperne fik spørgsmålet stillet på følgende måde: Hvis en person begår et drab, og herfor bliver idømt 4 års anbringelse i en anstalt, ville du så synes, at disse 4 år er ... osv. Gruppe 
nummer to fik samme spørgsmål, men med et »forslag« om 6 års anbringelse, og gruppe nummer tre ditto med et »forslag« om 8 års anbringelse. Opstilling 6.2.1 viser, hvordan svarene fordelte sig for de tre grupper.

Opstilling 6.2.1. Reaktionerne på, hvordan man synes, der skal foranstaltes for drab, på baggrund af et »forslag" om en bestemt foranstaltning vedrørende et givet antal års anbringelse $i$ anstalt. Telefonundersøgelsen. Procentfordeling ${ }^{*}$

\begin{tabular}{lccccccc}
\hline »Foreslået tid« & $\begin{array}{c}\text { Alt for } \\
\text { lang tid }\end{array}$ & $\begin{array}{c}\text { Noget for } \\
\text { lang tid }\end{array}$ & $\begin{array}{c}\text { Passende } \\
\text { kort tid }\end{array}$ & $\begin{array}{c}\text { Noget for } \\
\text { kolt for } \\
\text { kort tid }\end{array}$ & $?$ & I ALT \% \\
\hline 4 år & 2 & 1 & 14 & 14 & 64 & 5 & 100 \\
6 år & 2 & 3 & 25 & 18 & 49 & 3 & 100 \\
8 år & 2 & 5 & 37 & 14 & 37 & 5 & 100 \\
\hline
\end{tabular}

*n ved 4 år er 180, ved 6 år 177 og ved 8 år 170.

Fra metodologiske undersøgelser i forbindelse med retsbevidsthedsundersøgelserne i Danmark ved vi, at denne måde at spørge på primært er relateret til den generelle retsfølelse. »Forslaget « opfattes som et bud på, hvordan der faktisk dømmes, og har man således den holdning, at der generelt straffes eller foranstaltes for mildt, så har man - inden for vide grænser - også en tendens til at mene, at der for bestemte forbrydelser straffes for mildt, uanset hvilken forbrydelse, der er tale om, og uanset hvad der »foreslås«. I og med, at et flertal generelt synes, at der straffes for mildt, må man således også forvente, at der vil være et flertal, der synes, at de stillede »forslag « er for milde, op til et punkt, hvor man ikke længere mener, der i forslaget kan være tale om en beskrivelse af retspraksis. Dette viser sig da også at være tilfældet. I alle tre grupper er der et flertal, der synes, at henholdsvis 4, 6 og 8 års anstaltsanbringelse er for kort tid. Samtidig kan man dog tillige se, at det gør en forskel, hvad der »foreslås«. 78 pct. synes, at 4 år vil være for kort tid, 67 pct. synes at 6 år vil være kort tid og kun lige et knebent flertal, 51 pct., at 8 år vil være for kort tid.

At der primært er tale om et gennemslag af den generelle retsfølelse fremgår af, hvordan de personer, der generelt mener, at foranstaltningerne er for milde i Grønland, forholder sig til »forslagene« om 4, 6 og 8 års anstaltsanbringelse for drab. Når 4 år forslås, er det 93 pct. i denne gruppe, der synes, at det vil være for lidt; når 6 år foreslås, er det 79 pct., og når 8 år foreslås, er det 68 pct. - altså i alle tilfælde mindst to ud af tre, der synes, at det foreslåede er for lidt. Her over for står de personer, der generelt mener, at foranstaltningerne er passende eller for 
strenge. Når denne gruppe får »forslaget« om 4 år, svarer 55 pct., at de synes, det er for lidt; når forslaget lyder på 6 år, som er identisk med retspraksis, er det kun 36 pct., der synes, at det er for lidt - og når 8 år foreslås er det mindre end hver tredje, 31 pct.

Den måde, de tre grupper har fået stillet spørgsmålet på, har implicit den karakter, at den primært lægger op til at få svarpersonen til at tænke i »strenghed « i forhold til forbrydelsen fremfor andre mulige hensyn som ikke mindst resocialisering, samt at indsnævre de mulige valg af konkrete foranstaltninger til at dreje sig om (ubetinget) anstaltsanbringelse. Den fjerde og sidste gruppe i telefonundersøgelsen fik derfor stillet spørgsmålet om, hvordan de ville dømme i tilfælde af drab, på en måde, der i højere grad overlod til dem selv at afgøre, hvilke hensyn de ville tage ved valg af foranstaltning samt hvilke konkrete foranstaltninger der kunne komme på tale. Spørgsmålet havde følgende ordlyd: Hvis du skulle bestemme, hvilken dom synes du så en person, der har begået drab, skulle have? Svarmulighederne og svarene fremgår af opstilling 6.2.2. I tilfælde af, at de interviewede ville dømme til anbringelse i en anstalt, blev de supplerende spurgt om, hvor lang tid ca. de så ville synes, det var passende, at personen skulle idømmes.

\section{Opstilling 6.2.2. Svarfordeling i procent for følgende spørgsmål blandt}

18-74-årige i Grønland, 2014 (telefonundersøgelsen): Hvis du skulle bestemme, hvilken dom synes du så en person, der har begået drab, skulle have. ${ }^{36}$

\begin{tabular}{lr}
\hline En stor bøde og en stor erstatning til offeret & 9 \\
Samfundstjeneste i f.eks. 200 timer af hans fritid & 2 \\
Samfundstjeneste hver weekend gennem meget lang tid & 5 \\
Betinget dom med tilsyn og behandling & 32 \\
Anstalt, < 6 år & 6 \\
Anstalt, 6 år & 4 \\
Anstalt, > 6 år & 31 \\
Anstalt, ved ikke hvor lang tid & 9 \\
Vil ikke svare & 0 \\
Ved ikke & 2 \\
\hline I ALT procent & 100 \\
n $=$ & 170 \\
\hline
\end{tabular}

Herved afdækkes det - måske overraskende, i betragtning af hvor alvorlig forbrydelse, der er tale om - at kun lige netop præcis halvdelen (50 pct.) ville 
idømme ubetinget anstaltsanbringelse i det hele taget. 55 pct. ville enten ikke idømme en ubetinget anstaltsanbringelse i det hele taget eller en ubetinget anstaltsanbringelse på under de 6 år, der er den nuværende domspraksis. Når næsten hver tredje, 32 pct., ville idømme en betinget dom med tilsyn og behandling, må det igen ses som udslag af den betydning for valg af foranstaltning, som en stor del af den grønlandske befolkning tillægger det formål at hjælpe og støtte gerningspersonen, så han ikke begår ny kriminalitet.

Når spørgsmålet formuleres som et forslag om 6 års anstaltsanbringelse, så er det to ud af tre, der synes, at der skal mere til; når spørgsmålet formuleres mere åbent og med flere reaktionsmidler, så er det mindre end hver tredje, der synes, at der skal mere end 6 års anstaltsanbringelse til.

At vi med denne »fyldigere« måde at spørge på fjerner os fra spørgsmålet om den generelle punitivitet viser det forhold, at der her ikke er nogen forskel mellem tilbøjeligheden til at ville idømme ubetinget anstaltsanbringelse for den gruppe, der generelt mener, at foranstaltningerne er for milde, sammenlignet med den gruppe, der mener, at foranstaltningerne er passende eller for strenge. I den førstnævnte gruppe var der 51 pct., der ville idømme ubetinget anstaltsanbringelse, i den sidstnævnte gruppe 49 pct. Paradokset er tydeligt: Mens der blandt $\gg$ strammerne« er to ud af tre, der umiddelbart synes, at 8 års anstaltsanbringelse vil være for lidt til en drabsmand, så er det i den samme gruppe halvdelen, der mener, at der slet ikke skal anvendes ubetinget anstaltsanbringelse.

\subsection{Foranstaltninger ved partnervold}

Mens drab ganske vist forekommer med en betydeligt højere frekvens i Grønland end eksempelvis i Danmark, og er den alvorligste form for vold, så er vold, uden dødelig udgang, i nære relationer, herunder ikke mindst vold mod en partner (ægtefælle/kæreste, tidligere ægtefælle/kæreste) langt den mest udbredte. I såvel postundersøgelsen som i fokusgruppeundersøgelsen blev de interviewede bedt om at dømme i følgende sag:

Peter og Anna er gift og har boet sammen i 6 år. Sammen har de en datter på 4 år. Deres ægteskab har gennem det seneste års tid fungeret dårligt, og de skændes oftere og oftere.

Peter og Anna beslutter at forsøge at få talt ud om problemerne. De afsætter en weekend til at være sammen alene og skaffer en barnepige. Allerede fredag aften bliver de imidlertid uvenner, og det udvikler sig til et voldsomt skænderi. Peter forlader herefter lejligheden i vrede og går sammen med nogle venner $\mathrm{i}$ byen.

Anna er ked af, at aftenen har udviklet sig sådan, men ønsker ikke at sidde alene tilbage. Kort efter forlader hun derfor også lejligheden for at være sammen med nogle venner. 
I løbet af aftenen fortryder Peter, at de har forspildt muligheden for at få talt ud om tingene. Han ringer derfor flere gange hjem til Anna, som imidlertid ikke er hjemme. Peter forsøger også at ringe til Annas mobiltelefon, men der bliver ikke svaret, og Anna ringer ikke tilbage.

Peter tager tilbage til lejligheden klokken ca. 1 om natten. Kl. næsten 2 kommer Anna hjem. Peter vil vide, hvor Anna har været. Anna siger »Jeg gider ikke snakke med dig nu«. Peter vil imidlertid have talt ud og vil vide, hvor Anna har været. Anna svarer stadig ikke på Peter' spørgsmål og ønsker ikke at tale med ham.

Peter begynder at blive jaloux, fordi Anna ikke vil tale om aftenens forløb. Desuden er Peter sur over, at Anna tilsyneladende ikke er villig til at forsøge at få talt ud om deres problemer. Da Anna stadig ikke vil svare på Peters spørgsmål, begynder Peter at beskylde Anna for utroskab. Anna bliver gal, og de skændes højlydt og beskylder gensidigt hinanden for utroskab. Peter bliver mere og mere ophidset. På et tidspunkt siger Anna, at det vist er bedre at blive skilt. Peter bliver nu så ophidset, at han slår Anna hårdt i brystet. Anna vælter omkuld. Peter sparker 2 gange Anna i ryggen. Anna forsøger at værge for sig med hænderne, men Peter sparker igen Anna dels i siden og dels over hænderne og tildeler Anna yderligere et knytnæveslag, der rammer i baghovedet. Anna kommer på benene og råber, at nu er det definitivt slut. Anna løber herefter fra lejligheden. Anna henvender sig på skadestuen, hvor hun bliver undersøgt og røntgenfotograferet. Anna har blå mærker på brystet og på ryggen og har smerter i nakken, ryggen, ribbenene og nyrerne i de følgende 4-5 dage. Anna har desuden brækket 2 fingre på højre hånd. Anna søger straks om separation, og parret bliver siden skilt.

Peter er 32 år. Peter har hele sit liv boet i en by. Han har en almindelig familiemæssig baggrund og fast arbejde. Peter er ikke tidligere blevet dømt for nogen form for kriminalitet.

Svarmulighederne var her hele 34 forskellige foranstaltninger, omfattende alle hovedforanstaltninger i den grønlandske kriminallov, og underopdelinger af disse (eksempelvis forskellige tidsperioder for anbringelse i anstalt). Retspraksis i en sag som denne er i Danmark 3-4 måneders ubetinget fængsel og i Grønland 40 dages ubetinget anstaltsanbringelse, evt. 40 timers samfundstjeneste. Blandt de grønlændere, der i grupperne har haft denne sag i fokus, og som dels har haft lejlighed til at se retssagen med vidneafhøringer mv. på film, og dels sammen med de andre i gruppen at diskutere fordele og ulemper ved de forskellige foranstaltningsmuligheders anvendelse i netop denne sag, viser der sig kun at være 11 pct., der ville idømme ubetinget anstaltsanbringelse, heraf de 3 pct. under 2 måneder. Det store flertal ville idømme en betinget dom med tilsyn, samt eventuelt behandling. Hovedparten af de interviewede i fokusgruppeundersøgelsen (84 pct.) tror også, at praksis ved de grønlandske domstole er, at man i en sådan sag ikke idømmes ubetinget anstaltsanbringelse, ${ }^{37}$ og man tror, at de fleste grønlændere vil være enige heri, altså at der ikke skal idømmes en ubetinget anstaltsanbringelse. I de danske retsbevidsthedsundersøgelser finder man i partnervoldssagen som i de øvrige sager en klar tendens til, at den danske befolkning gennemgående ser sig selv som mildere, end de tror flertallet er i deres holdninger. En tilsvarende ten- 
dens findes ikke i den grønlandske undersøgelse. Grønlænderne har gennemgående den opfattelse, at deres egne holdninger er identisk med, hvad de fleste andre grønlændere mener.

\subsection{Foranstaltninger ved voldtogt}

En anden form for personovergreb (end »ren« vold), der som påvist såvel absolut som relativt udgør et betydeligt problem for og i det grønlandske samfund, er seksuelle overgreb. Vi har derfor også interesseret os for, hvordan den grønlandske befolkning synes, der skal foranstaltes i sådanne sager, eksempelvis i tilfælde af voldtægt.

Ligesom ved drab har vi ud fra et tilfældighedsprincip delt de interviewede op i fire forskellige grupper, og de tre af dem har vi »foreslået« en ubetinget anstaltsanbringelse i henholdsvis $1 / 2,1$ og $1 \frac{1}{2}$ år, og spurgt, hvorvidt de mente, dette var en passende dom, jf. opstilling 6.4.1. Den typiske foranstaltning for voldtægt idømt ved de grønlandske domstole er 1 års ubetinget anstaltsanbringelse, i Danmark efterhånden typisk længere.

Opstilling 6.4.1. Reaktionerne på, hvordan man synes, der skal foranstaltes for voldtcegt, på baggrund af et "forslag" om en bestemt foranstaltning vedrørende et givet antal års anbringelse $i$ anstalt. Telefonundersøgelsen. Procentfordeling ${ }^{*}$

\begin{tabular}{lccccccc}
\hline »Foreslået tid« & $\begin{array}{c}\text { Alt for } \\
\text { lang tid }\end{array}$ & $\begin{array}{c}\text { Noget for } \\
\text { lang tid }\end{array}$ & $\begin{array}{c}\text { Passende } \\
\text { 1ån }\end{array}$ & $\begin{array}{c}\text { Noget for } \\
\text { kort tid }\end{array}$ & $\begin{array}{c}\text { Alt for } \\
\text { kort tid }\end{array}$ & $?$ & I ALT \% \\
1 år & 0 & 0 & 7 & 13 & 78 & 2 & 100 \\
1 år & 1 & 1 & 15 & 15 & 65 & 3 & 100 \\
$1 / 2$ år & 1 & 1 & 17 & 17 & 60 & 4 & 100 \\
\hline
\end{tabular}

*n ved $1 \frac{1}{2}$ år er 180, ved 1 år 177 og ved $1 \frac{1}{2}$ år 170 .

På grund af et interview- og opgørelsesteknisk problem blev svarfordelingen for den fjerde gruppe, der - helt som ved drab - mere åbent blev spurgt om, hvordan de ville dømme for voldtægt forelagt en række forskellige mulige foranstaltninger, ikke fordelt på den planlagte måde for så vidt angår længden for dem, der pegede på ubetinget anstaltsanbringelse. Det fremgår dog, at der her på det generelle plan er et klart flertal, der ville idømme ubetinget anstaltsanbringelse (60 pct.), og altså flere end ved drab! »Kun« hver fjerde, 26 pct., ville idømme betinget dom med tilsyn og behandling $(n=170)$. 
Der er ved spørgsmålet om, hvordan der skal foranstaltes ved voldtægt, præcis de samme sammenhænge med den generelle holdning til, hvordan der skal foranstaltes, som vi så ved drab, og igen forholder det sig sådan, at der ved den »fyldigere« måde at spørge på ikke er nogen signifikant forskel med hensyn til, hvad »strammerne« og »slapperne« mener, der skal dømmes.

Voldtægt var den anden sag, der ved siden af ovennævnte partnervoldssag, blev fokuseret på i fokusgrupperne med visning af film mv. Den sag, de blev forelagt, var følgende:

Katrine og Poul som ikke kender hinanden, men de har mange fælles bekendte. De møder hinanden på Manhattan en fredag aften. De drikker sammen med fælles venner shots og danser ude på dansegulvet. De aftaler at tage videre til en efterfest efter, at Manhattan lukker klokken 03.

På vej mod efterfesten spørger Poul Katrine, om han ikke må give hende et knus. Katrine siger ja, og de giver hinanden et knus. Da de skal til at gå videre, inviterer Poul Katrine på en øl på hans værelse, som ligger på 1 sal i det hus, hvor efterfesten bliver afholdt. Katrine siger ja tak, og de følges ad til Pouls værelse.

Katrine sætter sig i en stol på værelset, og Poul sætter sig på sengen. Stemningen er god, de sludrer og drikker et par øl. Da Poul kommer tilbage efter et toiletbesøg, går han hen til Katrine og læner sig ind over hende, og begynder at kysse hende. Katrine siger, at det gider hun ikke. Hun tager fat $\mathrm{i}$ hans hænder og forsøger at skubbe dem væk. Poul ignorerer imidlertid hendes afvisning. Han trækker Katrines bluse op og lukker hendes BH op og rører ved og kysser hendes bryster, mens Katrine forgæves forsøger at skubbe ham væk. Katrine rejser sig og siger, at hun vil gå, men Poul tager fat $\mathrm{i}$ hende og trækker hende hen til sengen.

Katrine protesterer, og siger, at Poul skal lade hende gå. Poul overhører protesterne og trækker Katrines bukser, trusser og bluse af hende. Han presser hende ned i sengen og lægger sig oven på hende og holder hende fast. Samtidig får han sine egne bukser krænget ned, og presser sig op i Katrine, hvor han gennemfører et kort, vaginalt samleje. Da han har fået udløsning, trækker han sig ud og rejser sig fra sengen. Katrine løber ud på toilettet, tørrer sig hurtigt med et håndklæde og tager bukser og bluse på. Derefter samler hun resten af sit tøj, og forlader straks Pouls værelse.

Tidligt lørdag morgen ringer Katrine til sin søster, og fortæller, hvad der er sket. Søsteren bringer Katrine på SANA, hvor Katrine bliver undersøgt. Der konstateres ikke fysiske skader, men Katrine er chokeret, meget ked af det og bange. Om onsdagen -4 dage efter voldtægten fandt sted - anmelder Katrine sagen til politiet.

Poul er 28 år gammel og har boet hele sit liv i en by. Han har en almindelig familiemæssig baggrund og fast arbejde. Poul er ikke tidligere blevet dømt for nogen form for kriminalitet.

Slutresultatet af fokusgruppernes arbejde med at finde frem til, hvordan der burde dømmes i denne sag blev, at et flertal, 54 pct., syntes, at der skulle idømmes en ubetinget anstaltsanbringelse, men der var jo altså så alligevel 46 pct., der syntes, at det skulle man ikke - og som først og fremmest pegede på en betinget dom med tilsyn og behandling. ${ }^{38} 21$ pct. ville idømme en ubetinget anstaltsanbringelse 
på mindre end den nævnte retspraksis på 1 år, så det er i alt to ud af tre - 67 pct. der ville være »mildere« i deres domme end retspraksis, vurderet ud fra diskussionerne i fokusgrupperne først og fremmest af behandlingsmæssige og resocialiserende grunde.

Den mediant udmålte foranstaltning, som fokusgruppedeltagerne ville idømme for kontaktvoldtægten, var 4 måneders ubetinget anstaltsanbringelse. Der var en klar tendens til, at man undervurderede, hvor »streng « retspraksis faktisk var i denne slags sager, idet medianen med hensyn til, hvordan man troede sagen ville blive afgjort ved en domstol, var 50 dages ubetinget anstaltsanbringelse. Heri ligger således indbygget en tendens, som ses ved flere andre sager, til, at man ser sig selv som lidt »strengere« end domstolene, men faktisk er man »mildere«. Sammenlignet med situationen i Danmark, således som den fremgår af de der gennemførte retsbevidsthedsundersøgelser, er forskellene mellem, hvad man selv mener, hvordan man tror en domstol vil dømme, og hvordan man tror folk flest vil dømme, betydeligt mindre i Grønland. En usædvanlig - set med dansk målestok - stor del af den grønlandske befolkning er af den opfattelse, at sådan som de selv ville dømme også er sådan, som der ville blive dømt i kredsretten, og det er også sådan, de tror, folk flest i Grønland ville dømme.

\section{Reaktioner på kriminalitet - anstalterne}

Kriminalforsorgen i Grønland er en del af den danske statsadministration og er underlagt Justitsministeriet, Direktoratet for Kriminalforsorgen. I sit daglige virke opererer Kriminalforsorgen i Grønland imidlertid som en selvstændig organisation med kompetence på alle væsentlige sagsbehandlingsområder. Ledelsen af Kriminalforsorgen i Grønland er i kriminalloven bemyndiget til på en lang række områder at fastsætte regler om fuldbyrdelse af foranstaltninger og har i henhold hertil udsendt et stort antal bekendtgørelser (Kriminalforsorgen i Grønland, 2014).

I anstalterne indsættes personer, som enten er dømt til anbringelse eller som er tilbageholdte, mens deres sag behandles. Ved udgangen af 2013 var kapaciteten 194 pladser, fordelt på syv anstalter. I løbet af 2013 blev der foretaget 548 indsættelser, fordelt på 403 domfældte, 124 tilbageholdte og 21 anholdte. Kriminalforsorgen måler belægget i anstalter i form af belægstal fra de enkelte anstalter, og man beregner en samlet belægsmasse. Beregningen foretages ved, at én indsat, som opholder sig i en anstalt i ét døgn, indgår i beregningen med værdien 1. I 2013 var belægsmassen, beregnet på denne måde, 63.746, fordelt på 50.201 domfældte og 13.545 tilbageholdte. De domfældte har i 2013 således gennemsnitligt tilbragt omkring 4 måneder i anstalt, og de tilbageholdte omkring 3 måneder. Be- 
lægstallet i 2013, som er det i skrivende stund seneste, hvorom der foreligger en mere omfattende og detaljeret statistik, var dog atypisk, idet kapaciteten i hele året var midlertidigt forhøjet med 30 pladser (i Kangerlussuaq) med henblik på at afvikle en såkaldt »ventekø«. I 2014 har kapaciteten svinget fra 184 i de første tre måneder til 155 resten af året. ${ }^{39}$

Det gennemsnitlige belæg i 2013 var 175, hvilket er identisk med 309 pr. 100.000 indbyggere (International Centre of Prison Studies, 2015); 79 pct. var domfældte og 21 pct. tilbageholdte. I 2014 har det gennemsnitlige daglige belæg været 137, svarende til 241 pr. 100.000 indbyggere. ${ }^{40} 241$ indsatte på en gennemsnitsdag pr. 100.000 indbyggere er langt over det globale niveau, og 3-4 gange højere end i Danmark (og Norge, Sverige og Finland). I Island var der i 2013 gennemsnitligt 47 indsatte pr. 100.000 indbyggere og på Færøerne 21. Hos en anden nabo, i Canada, var der i 2012118 indsatte pr. 100.000 indbyggere. På en liste over brug af fængsler i hele verden i 2012/13 placerede Grønland sig som nr. 31 ud af i alt 202 lande, og i umiddelbart selskab med lande som Litauen (315), Iran og Sydafrika (290) og Brasilien (289). Blandt de forholdsvis få lande i verden, der i 2012/13 brugte fængsler/anstalter mere end i Grønland, var først og fremmest USA og en række lande med tæt tilknytning til USA (som Guam, Samoa, Puerto Rico m.fl.) (Walmsley, 2014).

Grønland har efterhånden i mange år placeret sig relativ højt ikke mindst $\mathrm{i}$ nordisk sammenhæng med hensyn til brug af anstaltsanbringelse, men det nuværende helt ekstraordinært høje niveau er resultatet af en kraftig stigning også i indeværende årtusinde. I 2000 var der gennemsnitligt 157 indsatte i de grønlandske anstalter pr. 100.000 indbyggere, altså »kun« omkring det halve sammenlignet med 2013, og det er en udvikling, der er sket til trods for, at kriminaliteten generelt i hvert fald ikke, som tidligere påvist, har været stigende i Grønland. ${ }^{41}$ Udviklingen synes at være et produkt af dels at idømme anstaltsanbringelse relativt oftere i kriminalsager og dels af relativt længere varighed, eksempelvis som ved drab. Der forefindes for tiden desværre ikke grønlandsk kriminalstatistik for årene efter 2009, men i 2000 var det 3 pct. af kriminalsagerne, der blev afgjort med anstaltsanbringelse og i 200911 pct. (Kriminalstatistikken for Grønland, 2000 og 2009; Grønlands Statistik). ${ }^{42}$

Situationen med hensyn til brug af anstaltsanbringelse i Grønland er blevet kaldt for »Den Store Grønlandske Indespærring« (Lauritsen, 2011; 2012) og bliver endnu mere paradoksal af, at det med den første kriminallov, der indførtes i Grønland i 1954, var hensigten, at Grønland slet ikke skulle have fængsler eller fængselslignende institutioner. Dette blev bl.a. kædet sammen med gerningspersonprincippet, hvor man forestillede sig, at succesfuld resocialisering skulle foregå i samfundet og 
ikke mere eller mindre uden for samfundet $\mathrm{i}$ et fængsel eller en anstalt (Goldschmidt, 1954). Til trods for intentionerne etableredes den første anstalt i Grønland i 1967. Denne anstalt blev opført i Nuuk og havde 18 pladser. Anstalten havde til at begynde med nærmest karakter af et kollegium - et »natfængsel« så at sige, med dansk terminologi - idet det forudsattes, at de indsatte skulle gå på arbejde uden for anstalten. Der opstod hurtig overbelægning, og flere anstalter kom til.

Det danske folketing har besluttet, at der skal bygges en ny anstalt i Nuuk til afløsning af den gamle anstalt fra 1967. Som et væsentligt element skal den nye anstalt udstyres med et lukket afsnit, som bl.a. skal tjene til fuldbyrdelse af forvaringsdomme og dermed sætte en stopper for godt 60 års »nedsendelse« af forvaringsdømte til Anstalten i Herstedvester i Danmark. Anstalten vil få 76 pladser, heraf $40 \mathrm{i}$ det lukkede afsnit. Efter planen skal anstalten stå klar til at blive taget $\mathrm{i}$ brug i slutningen af 2017. I telefonundersøgelsen blev den grønlandske befolkning stillet følgende spørgsmål: I 2017 skal en ny lukket anstalt for domfældte stå klar i Nuuk. Den får en høj mur rundt omkring sig og kommer til at ligne et fængsel. Hvad synes du om, at vi får sådan en anstalt?

Over halvdelen, 51 pct., svarede, at de syntes, dette var »Virkelig godt«, og yderligere 31 pct., at det var »OK«. Kun 5 pct. syntes, at det var »Helt forkert«. 10 pct. gav udtryk for, at de var »Noget skeptisk«, mens de resterende 3 pct. ikke havde nogen holdning til dette spørgsmål eller ikke ville svare.

Ud fra en forventning om, at mange har fundet ordningen med at »nedsende« forvaringsdømte til Danmark problematisk, fulgtes op med følgende spørgsmål: De grønlandske indsatte, som i dag afsoner i Herstedvester i Danmark, skal flyttes til den nye anstalt i Nuuk, når den er færdig. Hvad mener du om, at de Herstedvester-dømte fremover skal afsone i Grønland?

Her svarede mere end to ud af tre, 69 pct., at »Det er godt«. Yderligere 18 pct. svarede »Det er i orden - men gør mig utryg «, mens kun 10 pct. mente, at de skal blive i Herstedvester. Igen var det 3 pct., der svarede »Ved ikke«, eller som ikke ønskede at svare.

Når man igennem årtier har »nedsendt« forvaringsdømte grønlændere til afsoning i et lukket dansk fængsel, ville det være forkert at påstå, at man ikke har haft eller har lukkede anstalter i Grønland. Det er kun i geografisk forstand korrekt. Traditionelt har anstalterne på grønlandsk jord principielt været åbne, såvel i teknologisk og overvågningsmæssig henseende og som nævnt med hensyn til de indsattes muligheder for under anstaltstiden at befinde sig i lokalsamfundet uden for anstalterne.

Det kan i imidlertid diskuteres, om det (længere) er dækkende i teknologisk/overvågningsmæssig henseende at karakterisere anstalterne i Grønland som 
åbne. I vidt omfang er anstalterne eksempelvis blevet forsynet med bl.a. NATOpigtråd, panserglas for vinduerne, låste døre, kameraovervågning mv. Der opereres med »gårdtur« og »celler«, og man har begrænset mobiltelefoni.

I de eksisterende anstalter dominerer »cellerne«, og gennemgående er der få og små rum til øvrige aktiviteter, såsom beskæftigelse, undervisning og fritidsaktiviteter. Baggrunden herfor har netop været, at det aktive liv skulle foregå ude i lokalsamfundet, men sådan er det ikke (længere). Historisk har specielt beskæftigelsen af de indsatte hovedsageligt fundet sted uden for anstalterne, og arbejdsgiverne har typisk været positive over for at ansætte indsatte fra anstalterne. Arbejdsgiverne har ofte foretrukket de dømte frem for andre arbejdere; de er mere stabile (Greve, 2012). I 2013 foregik imidlertid hele 82 pct. af beskæftigelsen inden for anstalterne, mens blot 18 pct. foregik uden for. I 2014 synes det dog at være lykkedes at vende denne trend, så relativt flere af de indsatte (igen) beskæftiges uden for anstalterne, men dog ikke anderledes, end at flertallet stadig må afsone deres anstaltsdom i en temmelig lukket anstalt uden ret mange muligheder for noget at give sig til, først og fremmest på grund af anstalternes fysiske indretning.

En undersøgelse i Grønland har vist, at de rammer, der findes nu til dags for, hvad en foranstaltningsdom til ubetinget anstaltsanbringelse skal betyde, og hvad der foregår eller måske især ikke foregår under en anstaltsanbringelse, ikke blot paradoksalt nok står i kontrast til et samfund, hvor det hedder straf og fængsler, som f.eks. i Danmark, men også grundtanken i gerningspersonprincippet og resocialiseringsformålet (Lauritsen, 2012). I en avisoverskrift er det blevet udtrykt således:

»Den åbne anstalt er et fængsel i forklædning. De grønlandske anstalter er fængsler i forklædning, og forholdene er så pinefulde, at de nedbryder mange af de indsatte mentalt. Faktisk er vilkårene værre end i de lukkede anstalter« (Maria Hornbek Hansen, knr.dl/da/nyheder, 23. februar 2012).

De kvalitative dele af de gennemførte undersøgelser tyder på, at de fleste grønlændere ligger under for den fejlagtige opfattelse, at anstaltsanbragte som hovedregel har deres beskæftigelse ude i lokalsamfundet og har udgang til besøg mv., altså således som det faktisk forholdt sig tilbage i tiden. I telefonundersøgelsen stillede vi den grønlandske befolkning følgende spørgsmål vedrørende anbragtes mulighed for arbejde mv. i lokalsamfundet: Efter den grønlandske kriminallov indebærer anbringelse i anstalt for domfældte normalt, at de domfældte har større mulighed for at være beskæftiget med arbejde, uddannelse og fritidsvirksomhed uden for anstalten, end det kendes fra andre lande. Hvad synes du om denne ordning? Hele 77 pct. syntes, at denne ordning er ok, og godt en fjerdedel af befolkningen, 26 pct., syntes oven i købet, at man skulle gøre det i endnu højere grad, 
end (man formoder) ordningen aktuelt praktiseres. 23 pct. syntes, man skulle gøre det i mindre grad, og 3 pct. var uoplyste. Det skal understreges, at disse svar skal ses og fortolkes i perspektiv af, at »denne ordning « af de fleste grønlændere opleves som en ordning, hvor man hurtigt og som hovedregel arbejder uden for anstalten og går på besøg mv. For den majoritet af grønlændere, der syntes, at det primære formål med at foranstalte og bl.a. at afgøre, om der skal være tale om anstaltsanbringelse, er at hjælpe og støtte gerningspersonen, var der en endnu klarere hældning i retning af at mene, at man i højere grad end den oplevede situation, burde have mulighed for at komme ud og opholde sig uden for anstalterne. Selv blandt den lille minoritet af »straforienterede« var der 17 pct., der syntes at mulighederne for at komme og være uden for anstalten burde øges, og 40 pct. der synes, at det var passende som de forestillede sig, det var nu.

Men hvordan synes man det skal være, hvis det ikke blot drejer sig om den gennemsnitskriminelle med en relativ kort anstaltsanbringelse, men en person, der har begået en meget alvorlig personforbrydelse i det lokale samfund? I postundersøgelsen bad vi om den grønlandske befolknings stillingtagen til følgende sag:

Peter Olsen er ved kredsretten dømt til anbringelse i anstalt i 1 år og 8 måneder for i en sen nattetime at have begået voldtægt mod den mindreårige Sofie, som han havde mødt samme nat, da de hos en fælles bekendt deltog i en efterfest, som blev arrangeret, da byens diskotek lukkede kl. 3. Der blev drukket ret meget under festen. Peter og Sofie havde danset tæt sammen og kælet lidt med hinanden, men på et tidspunkt blev Sofie træt og faldt i søvn i et værelse i lejligheden. Peter fandt hende og begyndte at tage tøjet af hende, og da hun ikke gjorde modstand - tydeligvis fordi hun var så alkoholpåvirket, at hun ikke sansede, hvad der foregik - krængede Peter hendes bukser og trusser af og gennemførte et fuldbyrdet samleje med hende. Peter var klar over, at Sofie kun var 14 år gammel. Kredsretten fandt Peter skyldig i voldtægt begået mod en person under 15 år, idet han havde skaffet sig samleje med Sofie, der befandt sig i en tilstand, i hvilken hun var ude af stand til at modsætte sig handlingen - såkaldt »tilsnigelse« - og idet han vidste, at hun ikke var fyldt 15 år.

Peter, der er 31 år, bor i samme by, hvor han arbejder som chauffør og altmuligmand på byens hotel. Hans kone, Marie, 27 år, arbejder på fuld tid som pædagogmedhjælper i en daginstitution. De har to børn - Ivaana på 8 år, der går i skole og på fritidshjem, og Malik på 5 år, der går i børnehave.

Forud for dommen havde Peter været tilbageholdt i en måned, de første 13 dage i detentionen og resten af tiden i Anstalten for Domfældte. Da han havde fået sin dom, havde han således allerede på forhånd gennemført den første måned af anstaltstiden.

Straks efter dommen søger Peter om tilladelse til dagligt at forlade anstalten i arbejdstiden for at genoptage sit arbejde på hotellet. På hotellet har man været meget tilfreds med Peters arbejdsindsats, og man vil gerne beholde ham. Peter vil meget gerne genoptage arbejdet hurtigst muligt, dels for at bevare jobbet, dels for derved at kunne bidrage til familiens økonomi, idet Maries indtægt ikke alene kan klare familiens daglige udgifter. 
Samtidig søger Peter om tilladelse til at besøge familien i hjemmet i dagtimerne på fridage og efter fyraften på arbejdsdage, således at han returnerer til anstalten til sengetid. Han begrunder navnlig ansøgningen med hensynet til børnene, som savner deres far, og som Marie har svært ved at styre alene.

Peter har af personalet fået oplyst, at han vil have udsigt til ordinær prøveløsladelse efter to tredjedele af anbringelsestiden (dvs. efter et år, en måned og 10 dage), hvis det vurderes, at han har stabile personlige og sociale forhold, således at der ikke er væsentlig risiko for nye forbrydelser.

I forlængelse af denne sagsbeskrivelse blev der stillet følgende spørgsmål med følgende svarmuligheder:

Først med hensyn til hans ansogning om at måtte fortsætte med sit arbejde:

Hvad synes du om det?

\begin{tabular}{lccc}
\hline $\begin{array}{l}\text { Sat denne gang ét - og kun ét - } \\
\text { kryds i hver søjle: }\end{array}$ & $\begin{array}{c}\text { Hvad tror du, } \\
\text { at anstalten ville } \\
\text { svare på Peters } \\
\text { ansøgning om at } \\
\text { arbejde på hotellet? }\end{array}$ & $\begin{array}{c}\text { Hvad synes du } \\
\text { selv, at svaret } \\
\text { skulle være? }\end{array}$ & $\begin{array}{c}\text { Hvad tror du, } \\
\text { at folk i alminde- } \\
\text { lighed synes, at } \\
\text { svaret skulle være? }\end{array}$ \\
\hline
\end{tabular}

\section{Peter bør have tilladelse til straks} at kunne arbejde uden for anstalten

- uden særlige vilkår ...

- med særligt vilkår om, at han ikke opsøger ofret (Sofie) ...

Peter bør ikke have tilladelse til straks at arbejde, men først på et senere tidspunkt ...

- en uge efter dommen ...

- 14 dage efter dommen ...

- efter 2 måneders samlet anbringelse (inkl. tilbageholdelse) ...

- efter 6 måneders samlet anbringelse (inkl. tilbageholdelse) ...

- efter 10 måneders samlet anbringelse (inkl. tilbageholdelse) ...

Peter bor ikke på noget tidspunkt have tilladelse til at arbejde uden for anstalten 
Tilsvarende blev der efterfølgende med hensyn til Peter Olsens ansøgning spurgt om, hvad man syntes om muligheden for, at han måtte besøge familien på fridage og i aftentimer på hverdage. Svarfordelingerne fremgår af opstilling 7.1.

Opstilling 7.1. Holdning til, hvornår en indsat i en bestemt sag skal have lov til at fortscette med at arbejde udenfor anstalt og/eller besøge familie på fridage m.v. Postundersøgelsen. Procentfordeling

\begin{tabular}{lcc}
\hline & $\begin{array}{c}\text { Fortsætte med arbejde } \\
\text { udenfor anstalt }\end{array}$ & $\begin{array}{c}\text { Besøge familie på } \\
\text { fridage m.v. }\end{array}$ \\
\hline Straks, uden særlige vilkår & 9 & 15 \\
Straks, med særlige vilkår & 39 & 37 \\
1 uge efter dom & 4 & 3 \\
14 dg. efter dom & 8 & 9 \\
2 mdr. efter samlet anbringelse & $11^{*}$ & $9^{*}$ \\
6 mdr. efter samlet anbringelse & 6 & 5 \\
10 mdr. efter samlet anbringelse & 3 & 4 \\
Slet ikke & 18 & 18 \\
\hline I ALT & 100 & 100 \\
n $=$ & 269 & 250 \\
\hline
\end{tabular}

* Kriminalforsorgens praksis.

Relativt store andele uoplyste (»ved ikke«) vidner om, at det nok mere er undtagelsen end reglen, at befolkningen kender til praksis i sådanne sager, og det er øjensynligt heller ikke noget, de fleste (ofte) har diskuteret med andre, for der er endnu flere uoplyste, når man beder de interviewede gætte på, hvordan folk flest $\mathrm{i}$ Grønland ville mene, man skulle forholde sig til ansøgningerne. Af svarene på det ene bispørgsmål får vi bekræftet, at befolkningen har en ganske overdreven forestilling om mulighederne for at komme ud i lokalsamfundet under en anstaltsanbringelse. Over halvdelen, 51 pct., tror, at en indsat som Peter Olsen straks efter sin anbringelse i en anstalt kan komme ud og fortsætte sin beskæftigelse i samfundet, og 49 pct. at han straks kan komme på familiebesøg mv. (yderligere 6 pct. tror, for begge forhold, at det kan ske efter en uges anstaltsanbringelse).

Også når det drejer sig om egne holdninger spores der en relativ stor usikkerhed i befolkningen. 10 pct. har ikke svaret på spørgsmålet om udgang til beskæftigelse, og 16 pct. ikke på spørgsmålet om udgang til besøg hos familie mv. Der er i opstilling 7.1 set bort fra uoplyste. 
Den grønlandske kriminalforsorgs faktiske praksis i konkrete sager som denne er, at der ville kunne bevilges udgang til beskæftigelse og/eller til familiebesøg mv. efter 2 måneders samlet anbringelse (dvs. efter 10 pct. af den faktiske anbringelsestid). Det store flertal af den grønlandske befolkning, der har taget stilling, synes imidlertid, at det kunne/burde bevilges (meget) tidligere. 48 pct. syntes, at udgang til arbejde burde bevilges straks efter indsættelsen, eventuelt med særlige vilkår, og over halvdelen - 52 pct. - at udgang til at besøge familie mv. burde kunne bevilges med det samme. I alt er der 62 pct., der mener, at udgang til beskæftigelse burde kunne bevilges tidligere end praksis er, og 64 pct. med hensyn til udgang til familie mv. Knapt hver femte, 18 pct., var af den overbevisning, at personer som i den beskrevne sag ikke under deres anstaltsanbringelse overhovedet skulle have mulighed for udgang til beskæftigelse eller familiebesøg mv.

\section{Sammenfatning og konklusion}

I 1948-49 udsendtes fra Danmark en juridisk ekspedition til Grønland. Formålet var bl.a. dels at kortlægge, hvordan man i Grønland reagerede på kriminelle handlinger (»retspraksis«), og hvordan man syntes, der skulle og burde reageres (»retsbevidsthed«). Resultatet af dette arbejde blev en kriminallov, der trådte i kraft i 1954, og hvis styrende princip, såvel ved de foranstaltninger, der skulle kunne idømmes, som ved valg af foranstaltninger, primært var af individualpræventiv art, dvs. følge det såkaldte gerningspersonprincip - hvilket man mente var i overensstemmelse med grønlandsk sædvane, i handling som i holdning. Loven er blevet kaldt for verdens mest liberale kriminallov, ikke mindst fordi den implicerede, at der ikke skulle være fængsler i Grønland. Samtidig skulle den praktiseres i et kriminalretligt system domineret af ikke-jurister, ikke mindst som dommere og forsvarere (bisiddere). Udover at man på det tidspunkt (og for så vidt stadig den dag i dag) ikke praktisk havde mulighed for andet - og det var nok den vægtigste grund - så var rationalet, at det var de almindelige mennesker i det lille samfund, der kendte hinanden bedst, og således også bedst vidste, hvad der skulle til for at få en given person til at holde op med at begå kriminalitet.

Der er i tidens løb blevet rejst forskellige grundlæggende spørgsmål vedrørende ekspeditionens arbejde, der dels vedrører dens datagrundlag (som alene omfattede Vestgrønland og som tilsyneladende i langt højere grad omfattede kontakt med forskellige myndighedspersoner frem for almindelige mennesker) og dels de tolkninger af det, den så, hørte og læste: Var den individualpræventive tilgang faktisk den, der var dominerende i de grønlandske sædvaner, eller var det selektive briller og implicitte ønsker om, hvordan det kunne eller burde være, inspireret af tidens tanker i Europa, der i større eller mindre grad andre steder var resulteret 
i nye straffelove med en større vægt på gerningspersonprincippet end tidligere, herunder den danske straffelov af 1930 ?

I 2013-14 har der været udsendt en ny ekspedition til Grønland, og den har det tilfælles med den forrige, at den udsendte er dansk - med den særlige risiko dette giver for misforstålser og fejltolkninger. Kommissoriet denne gang har været mere begrænset end for 65 år siden, idet det næsten udelukkende - men dog ikke helt - har omhandlet »retsbevidsthed «. Til gengæld har datagrundlaget i 2013-14 været hele Grønland, og det har været den almindelige befolkning, der er blevet talt med, og som er blevet interviewet. I alt er der blevet talt med og interviewet omkring 1.200 tilsigtet repræsentative grønlændere i alderen 18-74 år. Samtalerne og interviewene er foregået på forskellig måde: Ca. 700 er blevet interviewet pr. telefon om mere generelle retsbevidsthedsmæssige spørgsmål (retsfølelsen), ca. 300 har besvaret postspørgeskemaer, der vedrørte stillingtagen til konkrete sager (retsfornuften), og ca. 200 har deltaget i fokusgruppemøder, hvor man også skulle tage stilling til konkrete sager, men her med betydelig mere information om sagerne (bl.a. via foreviste film) samt mulighed for diskussion med andre (igen her retsfornuften).

Man kan sige, at denne anden ekspedition til Grønland startede med Den Grønlandske Retsvæsenskommission, der var i funktion fra 1994-2000. Her arbejdede man også med at kortlægge og diskutere rettens arbejde, og det resulterede i den nye kriminallov og den nye retsplejelov, der begge trådte i kraft i 2010. I bakspejlet kan det undre, at denne kommission gjorde uforholdsmæssigt meget ud af »retspraksis«, forstået i sin brede forstand, og uforholdsmæssigt lidt ud af befolkningens »retsbevidsthed « - forarbejdet med og forudsætningerne for den eksisterende kriminallov fra 1954 taget i betragtning. Hvis dette læses som en bebrejdelse, er det i så fald også en selvbebrejdelse, fordi nærværende forfatter selv var medlem af kommissionens undersøgelsesgruppe! Hvor om alting er, så kom retsplejeloven af 2010 til at betyde, at man nedsatte Rådet for Grønlands Retsvæsen, og at det eksplicit af loven fremgår, at dette råd skal iværksætte relevant forskning og i sammenhæng hermed have en forsker som fast medlem - og det er ud af dette råd den nu gennemførte retsbevidsthedsundersøgelse i Grønland udspringer. Den gennemførte undersøgelses design og metode er modelleret efter tilsvarende undersøgelser gennemført i Danmark i 2006 og 2009, og i 2009 tillige i de øvrige nordiske lande - og er derfor til dels sammenlignelig med specielt undersøgelsen i Danmark i 2009.

Den grønlandske kriminallov fra 1954 er blevet kaldt for et socialt eksperiment, men eksperimentet har ikke været ledsaget af nogen kontrolgruppe, og i det hele taget ikke en plan for, hvordan det skulle evalueres. Det er klart, at det først 
og fremmest må vurderes og måles på kriminaliteten, men præcis hvordan? Umiddelbart er det svært at finde indikationer i retning af, at eksperimentet har været en succes, i hvert fald i det lange løb. Kriminaliteten har været stigende, stigningen løjer noget af i løbet af 1980-erne, og de aller seneste år har der været et fald. Dette svarer præcis til udviklingen i mange andre lande, herunder i Danmark. Ifølge de målinger, der er fortaget i forbindelse med retsbevidsthedsundersøgelsen, ligger den faktiske udsathed for person- og ejendomskriminalitet under ét i Grønland på et lidt højere niveau end i Danmark, og de kriminallovsovertrædelser, der ved anmeldelse eller på anden måde er kommet til politiets kundskab, set i forhold til folketallet, ligger også efter de seneste opgørelser (2013) på et højere niveau end i Danmark - en overhyppighed der er forstærket af en højere anmeldelsestilbøjelighed i Grønland. For personkriminalitetens vedkommende, såsom drab, vold og voldtægt, er niveauet mange gange større i Grønland end i Danmark, hvad enten man ser på den faktiske udsathed eller på kriminalstatistikken. En ud af hver tyve af de politiregistrerede straffelovsovertrædelser i Danmark er personforbrydelser, i Grønland er det tæt ved en ud af hver fire. To ud tre af de udspurgte grønlændere i den gennemførte telefonundersøgelse anser kriminaliteten for et være et meget stort problem i og for det grønlandske samfund, men tre uf af fire skænker dog aldrig eller kun sjældent risikoen en tanke for at blive udsat for kriminalitet i deres egen dagligdag. Det er langt fra at være et samfund, der er lammet af kriminalitetsfrygt. I modsætning til, hvad der faktisk er tilfældet, viser de fleste grønlændere sig at have en oplevelse af, at kriminaliteten har været stigende de seneste år, og der er et udbredt og stærkt ønske om, at der anvendes flere ressourcer på det kriminalitetsforebyggende arbejde.

Den mest simple forklaring på, at eksperimentet tilsyneladende ikke har virket, kan være, at det aldrig for alvor er blevet realiseret, og der er rigtig meget, der tyder på, at det forholder sig sådan. Teorien er ikke blevet omsat til praksis. Selv om man kan finde en række domme, der kan ses som udslag af et gerningspersonprincip, så er det tydeligt, at dommene stort set allerede fra starten i væsentlig grad fulgte et gerningsprincip, og dette er blevet tydeligere over tid. Der har udviklet sig et takstsystem, som først og fremmest følger gerningens alvorlighedsgrad, og med den nye kriminallov, der trådte i kraft i 2010, har man indskrevet, at de to hensyn, gerningsprincippet og gerningspersonprincippet, nu skal ligestilles ved valg af foranstaltning. I det danske straffesystem tages der også hensyn til personlige forhold ved strafudmålingen, og når man ser på praksis, kan man godt komme i tvivl om, hvorvidt der (længere) er nogen reel forskel mellem Grønland og Danmark i så henseende. - måske vil nogen vurdere, at det efterhånden forholder sig lige omvendt. Grønland skulle have været landet uden 
fængsler, men hurtigt fik man den første anstalt, hvor kriminelle kunne anbringes, og hurtigt begyndte man på en praksis med at sende forvaringsdømte til den lukkede forvaringsanstalt i Herstedvester i Danmark på ubestemt tid. I dag hører Grønland til i den øverste del på det globale landkort over, hvor mange man har siddende $\mathrm{i}$ anstalter/fængsler, set i forhold til folketallet - med tre-fire gange flere i anstalt/fængsel end i Danmark, idet man dog ved en sådan sammenligning må tage kriminalitetsmønstret med de relativt mange personforbrydelser i Grønland i betragtning. Sprogligt omtales anstalterne i Grønland som åbne, men efterhånden minder de mere om lukkede fængsler med deres udbredte brug af NATO-pigtråd, låste døre, kameraovervågning osv. I 2017 er selv æraen med de på papiret åbne anstalter i Grønland en saga blot, idet en ny anstalt i Nuuk her tages i brug, en anstalt der efter grønlandske forhold og i forhold til folketallet har et meget stort lukket afsnit. Det er ikke (længere) hovedreglen, som oprindelig tænkt, at de indsatte om dagen opholder sig uden for anstalterne (på arbejde mv.) - det har nu i flere år været undtagelsen. Samtidig er anstalterne på sin side gennemgående for små og for uhensigtsmæssigt indrettede til i noget videre omfang at kunne byde på arbejde, uddannelse og fritidsmuligheder.

Det viser sig, at såvel den grønlandske befolknings oplevelse af, hvordan situationen faktisk er, som holdningen til, hvordan det bør være, i flere og grundlæggende henseender mere er i tråd med sigtet i den oprindelige kriminallov fra 1954 end med den udvikling, der er sket siden, og situationen som den faktisk er i dag.

De fleste grønlændere tror, at anbringelse i anstalt anvendes langt mindre, end det faktisk er tilfældet, og de fleste tror, at det (stadig) forholder sig sådan, at det er det normale, at indsatte med det samme eller hurtigt får udgang og tilbringer dagen med arbejde og besøg i lokalsamfundet. I det hele taget er viden om ikke blot kriminaliteten og det kriminalretlige system i befolkningen gennemgående begrænset - og som nævnt ofte fejlagtig - til trods for at en tredjedel følger meget med i, hvad der sker på dette område, og yderligere en tredjedel en del med.

Det store flertal af grønlændere er af den opfattelse, at det primært styrende princip, når der skal reageres på kriminalitet, skal være det individualpræventive princip, dvs. gerningspersonen skal hjælpes og støttes til ikke at begå ny kriminalitet (gerningspersonprincippet). Et endnu større flertal synes, at dette også skal være det centrale princip, hvorefter de enkelte foranstaltninger indrettes, og selve den måde, de dømte reagerer på, f.eks. ved ikke at overholde de spilleregler, der er forbundet med de enkelte foranstaltninger, mener de fleste grønlændere først og fremmest skal imødegås med motiverende samtaler, behandling o.lign. Som en af de interviewede med et godt kendskab til systemet formulerede det, så burde man ikke have fået en kriminallov med en foranstaltningsstige, men i stedet 
for med et foranstaltningsfad. Fadet skulle i stil med foranstaltningsstigen byde på 6-8 mulige reaktioner, baseret på den viden man har om, hvad der bedst kan forebygge kriminalitet, såsom uddannelse/træning, behandling mv., herunder også diverse alternativer til anstaltsanbringelse såsom især samfundstjeneste (som findes i den nugældende lov) og konfliktråd. Domstolen skulle så have til opgave at vælge fra dette fad og dernæst - men som det sekundære - at tilpasse i forhold til et gerningsprincip: Er det her for mildt eller for hårdt, og hvilke justeringer eller tiltag skal der så i givet fald til/fra? Det er klart, at hvis man skulle revitalisere gerningspersonprincippet som udgangspunkt for, hvordan der kan og skal reageres i kriminalsager, så skal man lære af den internationale erfaring og skabe et værn mod de excesser, sådanne forsøg fik i mange lande i form af tidsubestemte straffe, uproportionalitet osv.

Der er ikke et flertal, der - som det måske var for 60-70 år siden - ønsker, at Grønland skal være uden fængsler eller fængselslignende institutioner, og der er udbredt tilfredshed med, at man får en ny anstalt i Nuuk, hvor bl.a. forvaringsdømte fremover kan afsone i stedet for i Danmark. Når man ser på, hvordan befolkningen synes, der konkret skal dømmes i alvorlige sager, så gør der sig som nævnt for det første en tendens gældende til, at befolkningen undervurderer, hvor ofte anstaltsanbringelse anvendes, og hvor lang tid, der idømmes, og for det andet en tendens til, at man synes, at anstaltsdommene burde være kortere. Disse vurderinger og holdninger gør sig især gældende for dem, der mener den individualpræventive tilgang bør være den primære, men langt fra udelukkende for dem. Med hensyn til indretningen af de anstalter, man nu engang mener, er nødvendige, kan man sige - måske lidt spidsformuleret - at befolkningen på dette område ønsker anstalterne tilbage til den måde, de startede på i 1950-erne: Som en bolig for dømte, der i øvrigt brugte dagen på arbejde mv. ude i lokalsamfundet; stort set fra dag ét eller kort tid efter indsættelse, og eventuelt med forskellige pålæg om, hvor man må være hvornår og/eller hvem man må være sammen med. Det styrende princip for, hvad der skal foregå i selve anstalterne bør, ifølge de flestes mening, være hjælp og støtte til at kunne klare en kriminalitetsfri tilværelse.

Vi har ikke haft mulighed for at belyse, hvad befolkningen ved og forestiller sig om selve retsplejen såsom f.eks. kredsdommernes baggrund og ansættelsesforhold, men kun holdningerne hertil. Der er flere, der synes, at det er fint med ordningen vedrørende kredsdommere (og forsvarere), som den er nu, end som ønsker, at det udelukkende skal være jurister, også selv om de er dansksprogede. Flertallet samler sig om, at der nok burde tilstræbes en noget højere grad af juridificering i form af øget uddannelse o.lign. af kredsdommere og forsvarere. Mange er sig sikkert også bevidste om, at det ikke inden for en overskuelig årrække 
overhovedet ville være realistisk, at alle kredsdommere og forsvarere skulle være jurister, og ikke mindst hvis det skulle være grønlandsksprogede jurister.

Selv om det i 1950-erne nok var praktiske forhold, der var hovedgrunden til, at det blev lægdomstole, der skulle fungere med den nye kriminallov, så blev det dog også ideologisk kædet samme med gerningspersonprincippet. En sådan sammenkædning er ikke at finde i den grønlandske befolkningsforestillinger anno 2014. Man opfatter det som to separate problemstillinger. Der er således ikke betydende forskelle med hensyn til holdningen til juridificering af domstolene set $\mathrm{i}$ forhold til, hvad man mener, skal være det styrende princip for reaktioner mod kriminalitet, gerningsprincippet eller gerningsprincippet. Den lille forskel, der er, går faktisk i retning af, at tilhængere af gerningsmandsprincippet går ind for en vis øget juridificering i højere grad end tilhængerne af gerningsprincippet. Det giver vel i dagens grønlandske samfund også god mening at adskille disse to problemstillinger, og mene, at for domstolenes vedkommende, og spørgsmålet om deres grad af juridificering, drejer det sig ikke så meget om, hvorvidt den primære ledetråd skal være gernings- eller gerningspersonprincippet, men om deres formåen og kapacitet til at skabe og producere ensartethed.

Det er selvfølgelig rent tankespind, men alligevel en principiel overvejelse værd, om det kunne være gået anderledes med kriminalloven i 1954 og de følgende år, dvs. om man kunne have realiseret og fastholdt gerningspersonprincippet. At det ikke lykkedes i noget videre omfang at realisere gerningspersonprincippet havde helt givet med andet end domstolsopbygning at gøre, først og fremmest den øvrige samfundsudvikling i Grønland. Jurister - gode jurister - er særligt gode til at fortolke, forstå og anvende en lovtekst, og i det her tilfælde forelå der jo en lov - skrevet og udarbejdet af andre jurister. Jurister - gode jurister - er også særligt gode til at få etableret en praksis - og at fastholde en praksis. Jurister - gode jurister - er særligt gode til at skabe ensartethed og lighed i forhold til nogle grundlæggende principper - uanset hvad principperne så end er! Måske havde en juridisk domstol derfor været bedre end en lægmandsdomstol, og de her nævnte egenskaber i situationen vigtigere end det læge element, idet der dog selvfølgelig under alle omstændigheder kunne have medvirket lægdommere. Selv om gerningspersonprincippet også dengang - som nu - var et element i den danske strafferet, så skulle det nok have været nogle jurister, der ikke var blevet alt for omfattende undervist i strafferetlige systemer, der som det danske i højere grad tog afsæt i gerningsprincippet, og så kunne man i givet fald også have risikeret at have fået nogle af de nævnte excesser med fra, hvordan dele af gerningspersonprincippet blev praktiseret i Danmark o.lign. lande. Mon ikke det først og fremmest skulle have været jurister, der var blevet oplært i, og som var blevet rigtige 
dygtige til civilret. Og selvfølgelig burde det have været en grønlandsk uddannelse - og grønlandske jurister.

\section{Litteratur}

Adriaenssen, A. \& Aertsen, I. (2015). »Punitive attitudes: Towards an operationalization to measure individual punitivity in a multidimensional way«, European Journal of Criminology, 12(1), s. 92-112.

Aebi, M.F. \& Kuhn, A. (2000). »Influences on the prisoner rate: The number of entries into prison, length of sentence and crime rate«, European Journal on Criminal Policy and Research, 8, s. 65-75.

Balvig, F. (1998). Vold på gaden, i hjemmet og på arbejdet. Oversigt over resultater fra voldsofferundersøgelsen 1995/96. Rigspolitichefen, København.

Balvig, F. (1999a). »Den faktiske kriminalitet i Grønland og Danmark«, I: Balvig, F. \& Krarup (red.): Grønland - på vej mod et nyt straffesystem?, Rapport fra NSfK's 41. forskerseminar Illulisat, Grønland, Nordisk Samarbejdsråd for Kriminologi, København, s. 46-51.

Balvig, F. (1999b). »Dommerne og de dømte i Grønland«, i Balvig, F. \& Krarup, N. (red.): Grønland - på vej mod et nyt straffesystem?, Rapport fra NSfK's 41. forskerseminar Illulisat, Grønland, Nordisk Samarbejdsråd for Kriminologi, København, s. 126-131.

Balvig, F. (2006). Danskernes syn på straf. Advokatsamfundet, København. 391 s.

Balvig, F. (2010). Danskernes retsfølelse og retsfornuft - et forspil. Det Juridiske Fakultet, Københavns Universitet. $200 \mathrm{~s}$.

Balvig, F., Gunlaugsson, H., Jerre, K., Olaussen, L.P. \& Tham, H. (2010). »Den nordiske retsbevidsthedsundersøgelse «, Nordisk Tidsskrift for Kriminalvidenskab, Nr. 3, s. 232-250.

Balvig, F., Gunlaugsson, H. \& Tham, H. (2011). »Ikke kun strenghed - replik om de nordiske retsbevidsthedsundersøgelser«, Nordisk Tidsskrift for Kriminalvidenskab, , Nr. 3, s. 228-238.

Balvig, F. (2015a). Retsfølelse og retsfornuft - i Danmark. Metoder og materialer, 2006 og 2009. $289 \mathrm{~s}$.

Balvig, F. (2015b). Retsfølelse og retsfornuft - $i$ Grønland. Metoder og materialer, 2014. Nordisk Samarbejdsråd for Kriminologi. $510 \mathrm{~s}$.

Balvig, F., Gunlaugsson, H., Jerre, K. \& Tham, H. (2015). »The public sense of justice in Scandinavia: A study of attitudes towards punishments«, European Journal of Criminology, 12, s.1-20.

Barcley, G.C. (2000). »The comparability of data on convictions and sanctions: Are international comparisons possible?«, European Journal on Criminal Policy and Research, 8, s. 13-26.

Boesen Pedersen, A.-J., Kyvsgaard, B. \& Balvig. F. (2014). Udsathed for vold og andre former for kriminalitet. Offerundersøgelserne 2005-2015 med sarligt afsnit om køn og vold. Justitsministeriet, København. $168 \mathrm{~s}$.

Breinholt Larsen, F. (1999). »Den grønlandske kriminallov som ideologisk konstruktion«. I: Balvig, F. \& Karup, N. (red).: Grønland - på vej mod et nyt straffesystem?, Nordisk Samarbejdsråd for Kriminologi, København, s. 90-96.

Breinholt Larsen, F. (2002). Kriminaliteten I Grønland. Omfang, årsager og handlemuligheder. Udgivet af Den Grønlandske Retsvæsenskommission, Rapport nr. 7. Direktoratet for Kriminalforsorgen. 
Christensen, E., Kristensen, L.G. \& Baviskar, S. (2008). Børn i Grønland. En kortloegning af 014-årige børns og familiers trivsel. SFI - Det Nationale Forskningscenter for Velfærd, København.

Christie, N., Andenæs, J. \& Skirbekk, S. (1965). »A study of self-reported crime«. I: Karl O. Christiansen: Scandinavian Studies in Criminology, Vol. 1, Universitetsforlaget, Oslo, s. 86116.

Epinion (2013). Danskernes forestillinger om kriminalitet. Det Kriminalpræventive Råd, København.

Goldschmidt, V. (1954). »Den grønlandske kriminallov og dens sociologiske baggrund «, Nordisk Tidsskrift for Kriminalvidenskab, s. 242-268.

Goldschmidt, V. (1963). »New Trends in Studies on Greenland Social Life«. I: Folk, vol. 5, s. 199.

Goldschmidt, V. (1973). »Social Tolerance and Frustration. An Analysis of Attitudes Toward Criminals in a Changing Arctic Town«, International Journal of Sociology, vol. 3, s. 147163.

Greve, V. (2012). Traek af kolonistrafferetten i komparativ belysning. Jurist- og Økonomforbundets Forlag, København.

Grønlands Domstole 2014, udgivet af Grønlands Domstole, Retten i Grønland, Nuuk.

International Centre of Prison Studies (2015). www.prisonstudies.org/country/greenlanddenmark

Justitsministeriet (2015). Bekymring for vold og kriminalitet 2014. Justitsministeriets Forskningskontor, København.

Kahneman, D. (2012). Thinking, Fast And Slow. Penguin Books, Great Britain.

Kriminalforsorgen i Grønland (2014). Arsberetning 2013. Nuuk.

Kutchinsky, B. (1970). Den almindelige retsbevidsthed. Almqvist \& Wiksell, Stockholm.

Kyvsgaard, B. \& Boesen Pedersen, A.-J. (2012). Danskernes holdning til kriminalitet, straf, politi og domstole m.v. En sammenligning med andre europceere. Justitsministeriets Forskningskontor, Justitsministeriet, København.

Lappi-Seppalä, T. (2010). »Explaining variations in the use of imprisonment in developed democracies«, I: Lemann Kristensen, B. \& Storgaard, S. (red.): Nordisk retssociologi. Status aktuelle udfordringer - visioner. Jurist- og Økonomforbundets Forlag, København.

Lappi-Seppalä, T. (2011). »Explaining imprisonment in Europe«, European Journal of Criminology, 8(4), s. 303-328.

Lauritsen, A.N. (2011). Anstalten - frihedsberøvelse i Grønland. Ph.d.-afhandling, Ilisimatusarfik, Nuuk.

Lauritsen, A.N. (2012a). »Anstalten i Grønland«, Materialisten, 39. årgang, 2-3, s. 11-15.

Lauritsen, A.N. (2012b). »Greenland's Open Institution - Imprisonment in a Land without Prisons«, Journal of Scandinavian Studies in Criminology and Crime Prevention, vol. 13 (1), s. 47-56.

Mathiesen, T. (1965). Tiltak mot ungdomskriminalitet. En opinionsundersøkelse. Universitetsforlaget, Oslo.

Meinel, F. (1996). Gerningsmandsprincippet. Speciale ved Det Juridiske Fakultet, Københavns Universitet. 
Olaussen, L.P. (2011). »De nordiske rettsbevissthetsundersøkelsene - noen metodiske betraktninger«, Nordisk Tidsskrift for Kriminalvidenskab, Nr. 3, s. 209-227, s. 239-244.

Putnam, R.D. (2001). Bowling alone. The collapse and revival of American community. A Touchstone Book, Published by Simon \& Shuster, New York.

Skydsbjerg, H. (1996). Befolkningen og politiet. En undersøgelse af den grønlandske befolknings erfaringer med og holdninger til politiets arbejde. Den Grønlandske Retsvæsenskommission, Justitsministeriet. København.

Therbild, N. (1965). Kriminallovens foranstaltningssystem, bind I og II. København.

Tinggaard Svendsen, G. (2014). Trust. Aarhus Universitet.

Van Dijk, J. (2008). The World of Crime. Breaking the Silence on Problems of Security, Justice, and Development Across the World. Sage Publications, London.

Walmsley, R. (2014). World Prison Population List. 10. udg., International Centre for Prison Studies, London.

Vestergaard, J. (1999). »Dommerkvalifikationer i byretter og kredsretter«, i Balvig, F. \& Krarup, N. (red.): Grønland - på vej mod et nyt straffesystem?, Rapport fra NSfK's 41. forskerseminar Illulisat, Grønland, Nordisk Samarbejdsråd for Kriminologi, København, s. 132141.

\section{Noter}

1. Flemming Balvig, professor, dr. jur., mag.scient.soc. er ansat som professor i kriminologi ved Det Juridiske Fakultet, Københavns Universitet, Studiestræde 6, 1455 København K. Mail: flemming.balvig@jur.ku.dk

2. Teknisk information vedrørende analyser og præsentation af undersøgelsens resultater: Anvendte notationer mv.: $-=$ der findes ingen i denne kategori; $0=$ der findes mindre end 0,5 pct. i denne kategori; $\mathrm{n}=$ antal personer. For overskuelighedens skyld benævnes alle tabeller, billeder, figurer mv. for »opstillinger«. Det kan skifte fra opstilling til opstilling, hvorvidt uoplyste, ved-ikke besvarelser o.lign. er medtaget. Derfor kan der også forekomme mindre forskelle i procentfordelinger mv. for svarene på det samme spørgsmål. Ved såkaldte »krydstabuleringer«, hvor de enkelte forhold sættes i forhold til hinanden - f.eks. køn og holdning til hvad det primære formål skal være med at foranstalte/straffe - er uoplyste i de fleste tilfælde ikke medtaget. Derfor kan der her forekomme afvigende procenter i forhold til, når man alene ser på hyppigheden af enkelte forhold. Som hovedregel angives procenter uden decimal, da der er tale om relativ små tal. På grund af afrundinger kan det derfor også forekomme, at totaler for procenter ikke giver 100, men 99 eller 101.

3. Undersøgelserne har direkte eller indirekte været finansieret af Justitsministeriet i Danmark (Justitsministeriets Kriminalpolitiske Forskningspulje), Grønlands Selvstyre (Departementet for familie og Justitsvæsen), Politiet i Grønland, Kriminalforsorgen i Grønland, Landsdommerembedet i Grønland, Grønlands Universitet (llisimatusarfik) og Københavns Universitet (Det Juridiske Fakultet). HS Analyse ved Henrik Skydsbjerg har stået for den tekniske gennemførelse af undersøgelserne og dataindsamlingen.

4. Med henblik på igangsættelse af undersøgelsen blev der etableret en »fremdriftsgruppe« bestående af følgende personer: Politimester Bjørn Tegner Bay (i en periode med Claus Bæk Lyngholm Risbjerg som stedfortræder), Politiet i Grønland; Direktør for Kriminalforsorgen i Grønland, Hans Jørgen Engbo; Advokat Anders Meilvang; Departementchef Susie Martin 


\section{Flemming Balvig}

Kjeldsen, Grønlands Selvstyre; Landsdommer Søren Søndergaard Hansen, Grønlands Landsret; Professor Flemming Balvig, Københavns Universitet - alle medlemmer af Rådet for Grønlands Retsvæsen. På tidspunktet for undersøgelsens opstart bestod Rådet for Grønlands Retsvæsen i øvrigt af: Forhenværende Højesteretsdommer Per Walsøe (formand); Departementschef Anne Kristine Axelsson, Justitsministeriet; Dommer Birgit Skriver, Retten i Grønland; Helga Rosing, Forsvarerforeningen i Grønland; Vicedirektør Annette Esdorf, Direktoratet for Kriminalforsorgen; Direktør Charlotte Münter, Domstolsstyrelsen; Seniorrådgiver Kent Fridberg, Grønlands Selvstyre; Bjarne Petersen, Kanukoka (de grønlandske kommuners landsforening). I øvrigt har bl.a. følgende personer ydet vigtige bidrag til undersøgelsens gennemførelse: Andreas Emil Christensen, Taitsiannguaq Fleischer, Nina Paninnquaq Skydsbjerg Jacobsen, Ellen Kjærgaard, Annemette Nyborg Lauritsen, Myrna Lynge, Linda Kjær Minke, Rosa Reimer, Klaus Toftgaard og Jimmy Bøgh Veitland. De beskrivelser, analyser, fortolkninger, vurderinger og synspunkter, der fremsættes i artiklen, er forfatterens egne og alene hans ansvar.

5. Det følgende er en forholdsvis summarisk gennemgang af undersøgelsens design og de anvendte metoder og materialer. En mere udførlig og systematisk gennemgang findes hos Balvig, $2015 \mathrm{~b}$.

6. Der er i skrivende stund betydelige dele af de indsamlede data, der endnu venter på at blive analyseret. Selv om nærværende artikel er at betragte som hovedrapporten vedrørende de gennemførte undersøgelser, så er det tænkeligt, at den vil blive suppleret på forskellig vis. Det betyder også, at de tal og konklusioner, der præsenteres i nærværende artikel principielt er foreløbige, men der er dog ikke umiddelbart grund til at tro eller forvente, at der i væsentlig grad kan eller vil ske ændringer heri.

7. Der vil ikke i nærværende fremstilling blive gået i dybden med selve begrebsdannelsen vedrørende retsfølelse.

8. Grønlandske børns faktiske udsathed for seksuelle krænkelser er også blevet kortlagt i andre undersøgelser, der udviser tilsvarende høje frekvenser for denne form for overgreb (jf. især Christensen, Kristensen \& Baviskar, 2008).

9. I den geografiske opdeling er der anvendt følgende opdeling: Sydgrønland: Nanortalik, Qaqortoq, Narsaq og Paamiut; Nuuk: Nuuk; Midtgrønland: Maniitsoq og Sisimiut; Diskobugten: Kangaatsiaq, Aasiaat, Qasigiannguit, Ilulissat og Qeqertarsuaq; Nord- og Østgrønland: Uummannaq, Upernavik, Qaanaaq, Tasiilaq og Illoqqortoormiut.

10. I forbindelse med Den Grønlandske Retsvæsenskommissions arbejde blev der fortaget en omfattende sammenligning af den registrerede kriminalitets omfang og udvikling forud for den tidsperiode, offerundersøgelserne dækker over, nemlig 1952-1999 (Breinholt Larsen, 2002). Kortlægningen viser, at der i Grønland fra 1952 til midten af 1980-erne skete en kraftig vækst i antallet af registrerede kriminallovsovertrædelser, som herefter blev afløst af en mere moderat stigning (og kan det så tilføjes, som nu de seneste år er afløst af et fald). Kortlægningen bestyrker de gennemførte offerundersøgelsers konklusion om, at personkriminalitet i form af vold, seksuelle overgreb mv. har en særlig høj forekomst i Grønland. Følgende registrerede kriminallovsovertrædelser forekom således oftere i Grønland set i forhold til befolkningsstørrelsen: voldtægt (26 gange så hyppigt), incest, seksuel omgang med børn og blufærdighedskrænkelser (7 gange), andre seksualforbrydelser (11 gange), drab (11 gange), drabsforsøg (8 gange)og vold (6 gange). Rapporten indeholder også en analyse af sammen- 
hængen mellem kriminaliteten på den ene side og samfundsudviklingen på den anden fra 1952-1999. Ser man alene på et enkelt år kan store tilfældigheder spille ind, men med dette forbehold var situationen i 2013 for anmeldte kriminallovsovertrædelser i Grønland (jf. Årsstatistik fra Politiet i Grønland) og straffelovsovertrædelser i Danmark (jf. Danmarks Statistik), korrigeret for forskelle i folketal: Grønland havde 31 gange flere voldtægt, 8 gange flere blufærdighedskrænkelser og 12 gange flere seksualforbrydelser under ét; 15 gange flere drab, 10 gange flere drabsforsøg, 6 gange flere voldtilfælde og 5 gange flere vold under ét. Til gengæld var der i Grønland 20 pct. færre ejendomsforbrydelser, men her varierede det meget for de enkelte typer af ejendomsforbrydelser: Grønland havde 28 pct. flere røverier, 3 gange flere butikstyverier, dobbelt så mange indbrud i virksomheder o.lign., 4 gange flere indbrud i både, hytter, sommerhuse o.lign. Til gengæld havde Grønland $67 \mathrm{pct}$. færre indbrud i beboelser, 81 pct. færre brugstyverier og 50 pct. færre andreformer for tyveri. Andet end personforbrydelser og ejendomsforbrydelser var der 5 gange flere af i Grønland. Samlet set resulterede det i et antal registrerede kriminallovsovertrædelser, der var 10 pct. større end det samlede antal registrerede straffelovsovertrædelser i Danmark, stadig korrigeret for forskelle i folketal. Af det samlede antal registrerede kriminallovsovertrædelser udgjorde personforbrydelserne i Grønland 23 pct., i Danmark knapt 5 pct.

11. Når det er en kvinde, der er blevet interviewet af en mand, er det 64 pct., og når det er en mand, der er blevet interviewet af en kvinde, 67 pct.

12. I 1951 reformeredes retsplejen, og de nye retter begyndte straks at anvende et eksisterende udkast til en kriminallov.

13. Den juridiske ekspedition bestod af tre unge danske jurister (den senere professor i samfundsvidenskab ved Roskilde Universitets Center Agnete Weis Bentzon (1918-2013), (den senere professor i kultursociologi ved Københavns Universitet) Werner Goldschmidt (19161982) og (den senere rigsadvokat) Per Lindegaard (1918-1998). Ekspeditionen fandt sted i 1948-49, hvor de på de grønlandske vestkyst forsøgte at kortlægge retspraksis, retsbevidsthed osv. I deres rapport fra 1950 konkluderer de, at den grønlandske opfattelse af, hvad der burde være strafbart $i$ det store og hele svarede til den danske, mens de anvendte reaktioner og befolkningens ønsker om, hvordan disse burde være og hvorfor, var meget anderledes. Den grønlandske befolkning lagde, ifølge ekspeditionens opfattelse vægt på, at reaktionerne var udformet på en sådan måde, at de ved at ændre gerningspersonens personlige forhold kunne mindske risikoen for fremtidig kriminalitet, og at dette også var hovedformålet med reaktionerne.

14. Det drejer sig først og fremmest om en række helt eller delvist tidsubestemte foranstaltninger, der dog siden enten er blevet helt afskaffet eller har fået et meget snævrere anvendelsesområde. Generelt er den danske straffelovs sanktionssystem blevet radikalt ændret siden 1930.

15. En undersøgelse foretaget af et udvalg af domme i Grønland, afsagt i perioden 1992-96, understøtter tesen om, at med mindsket identifikationsmulighed bliver resocialiseringshensynet mindre fremtrædende, og de idømte foranstaltninger gennemgående strengere (Meinel, 1996; Balvig, 1999b).

16. Man kan godt rejse spørgsmålet om, hvor store forskellene i så henseende reelt længere er mellem Grønland og Danmark. På den ene side er det tydeligt, at dommene i kriminalsager i Grønland er blevet meget takstmæssige, primært relateret til gerningens art og alvorlighed, 


\section{Flemming Balvig}

og på den anden side forholder det sig jo også sådan, at personlige forhold i forskellige sammenhænge og i forskellige grad indgår ved udmålingen af straf i kriminalsager i Danmark. I den danske straffelovs $\S 80$ om straffens fastsættelse hedder det: »Ved straffens fastsættelse skal der under hensyn til ensartethed i retsanvendelsen lægges vægt på lovovertrædelsens grovhed og på oplysninger om gerningsmanden.« Af flere af de øvrige paragraffer i den danske straffelovs kapitel om straffens fastsættelse fremgår det, at forhold vedrørende gerningspersonen og gerningspersonens forhold kan tillægges vægt ved straffastsættelsen.

17. I den oprindelige kriminallov, der trådte i kraft 15. juli 1954, var det dog $\S 86$, stk. 2 , men ordlyden var ikke blevet ændret frem til 2010.

18. Der er grund til at tro, at de svar, der fremkommer, vil være sensitive over for, hvordan spørgsmålet præcist formuleres. Eksempelvis er der i det anvendte spørgsmål brugt ordene »hjælp og støtte«. I visse kulturer/samfund kan man forestille sig, at dette i forbindelse med sociale afvigelser og social kontrol vil være stærke og positivt ladede ord, mens det måske i andre vil være svage og negative (jf. det danske begreb pladderhumanisme). Det burde måske derfor være bedre blot at spørge om at mindske risiko for ny kriminalitet el.lign.

19. Allerede i en undersøgelse foretaget i Danmark i 1954 forsøgte man at afdække, hvad befolkningen synes burde være det primære formål med at reagere over for kriminalitet (Kutchinsky, 1970). Undersøgelsen er ikke repræsentativ, og desværre spurgte man ikke om formålet med at reagere over for kriminalitet, men om formålet med at straffe: » Hvorfor synes De, man skal straffe lovovertrædere?« Svarmulighederne var åbne og op til svarpersonerne selv. Af de seks undersøgte grupper var det mellem 7 og 19 pct., der svarede på en måde, som kunne indpasses under overskriften »Forbedring el. belæring «. I andre tidlige undersøgelser i de nordiske lande er der anvendt lignende spørgsmål, men med faste svarkategorier. Mathiesen foretog en undersøgelse i Norge, hvor der var seks svarmuligheder. Det hyppigste svar vise sig at være »lovbryderen skal tage skræk « (Mathiesen, 1965). I en anden undersøgelse fra 1960-erne foretaget i Norge blev der kun givet tre svarmuligheder, nemlig afskrække, behandle og sone., og svarene fordelte sig nogenlunde ligeligt på disse tre muligheder (Christie, Andenæs \& Skirbekk, 1965).

20. Blandt de, der synes, at det primære formål er resocialisering, er der 75 pct., der synes, at det næst vigtigste er at straffe, og »kun« 25 pct. at det er at afskrække andre fra at begå kriminalitet.

21. Dette tillægsspørgsmål blev ikke stillet i undersøgelsen i Danmark.

22. Også blandt de mænd og kvinder, der har oplevet sig udsat for alvorlig sexkrænkelse, mens de var børn eller unge, er der en lille overvægt af personer, der synes, at det primære formål skal være resocialisering, sammenlignet med dem, der ikke har været udsat.

23. Blandt de, der synes at kriminalitet er et meget stort problem for det grønlandske samfund, er der 82 pct., der mener, at hjælp og støtte bør være det primære, mens der blandt de, der ikke synes, at kriminalitet er et meget stort problem, er 73 pct. Blandt de, der næsten hele tiden eller ofte tænker på deres personlige risiko for at blive udsat for kriminalitet, mener 85 pct., at hjælp og støtte bør være det primært, over for 78 pct. af de mindre eller ikke ængstelige.

24. Jf. »Kriminalforsorgen i Grønland. Årsberetning 2013«. Se: www.kriminalforsorgen.gl 
25. Holdningen til kredsdommernes rekruttering og baggrund fordeler sig på samme måde blandt de svarpersoner, der i deres barndom eller ungdom har været udsat for alvorlige sexkrænkelser, som dem der ikke har det.

26. Tallene er meget små, men umiddelbar ligner procentfordelingerne for de adspurgte dommere meget procentfordelingerne for de adspurgte domsmænd.

27. Særlig markant er det, at næsten ingen i bygdernes synes, at kredsdommerne alle skulle være uddannede jurister.

28. For en oversigt over den internationale forskning vedrørende punitivitet $i$ befolkningen, og hvordan dette måles, se Adriaenssen, A. \& Aertsen, I. (2015).

29. Der er ingen forskel mellem dem, der vurderer deres viden som liggende på det gennemsnitlige, og dem der vurderer deres viden som liggende under det gennemsnitlige.

30. I tråd hermed fordeler holdningen til, hvorvidt man synes foranstaltningerne gennemgående er for milde, sig generelt på samme måde, for dem der for nylig har været udsat for en eller anden forbrydelse og/eller været udsat for en alvorlig sexkrænkelse, da man var barn/ung. Ser vi på de specifikke typer af forbrydelser, man kan have været udsat inden for den senere tid forud for interviewtidspunktet, nuanceres billedet lidt, men ikke i alle tilfælde på den måde, man umiddelbart kunne forvente. Udsathed for tyveri gør ingen forskel. Om man har været udsat for tyveri, og/eller om man som kvinde har været udsat for en alvorlig sexkrænkelse gør ingen betydende forskel. Udsatte for såvel vold som trusler om vold har i noget mindre omfang end de ikke-udsatte den overbevisning, at foranstaltningerne gennemgående er for milde, mens det er modsat - og som »intuitivt forventet« - for de, der har været udsat for hærværk.

31. På det konkrete plan - i konkrete sager - forholder det sig derimod ofte modsat.

32. Dette skal ikke forstås sådan, at de der ikke ønsker strengere foranstaltninger/straffe, ikke ønsker mere behandling, kriminalitetsforebyggende arbejde mv. eller i mindre grad., men alene på den måde, at de, der ønsker strengere foranstaltninger/straffe typisk også ønsker flere ressourcer brugt på behandling osv.

33. Jf. data og analyse af disse downloadet fra det såkaldte General Social Survey, i USA. (www.norc.org/ Research/Projects/pages/general-social-survey.aspx

34. Jf. www.ojp.usdog.gov

35. Den sondring, der anvendes i nærværende artikel, mellem retsfølelse og retsfornuft, og den forankring disse to tænkemåder kan have i menneskets grundlæggende evolutionære natur og samfundsmæssig socialisering, kan genfindes i mange andre sammenhænge, og er også overordnet beskrevet og analyseret på forskellig måde. Psykologerne Keith Stanovich og Richard West har benævnt de to tænkemåder/reaktionsmåder henholdsvis som System $1 \mathrm{og}$ System 2, og nobelprisvinderen Daniel Kahneman har anvendt begreberne »Fast Thinking« og »Slow Thinking « (Kahneman, 2012).

36. To af de sanktionsmuligheder, svarpersonerne her har fået at vælge imellem, eksisterer ikke præcis på denne måde i den grønlandske kriminallov. Det er »Samfundstjeneste hver weekend gennem meget lang tid« og »Betinget dom med tilsyn og behandling«.

37. På det generelle plan er der en tendens til at undervurdere, i hvilken grad de grønlandske domstole idømmer ubetinget anstaltsanbringelse i tilfælde af vold. Ifølge det grønlandske politi idømmes ubetinget anstaltsanbringelse i 30-50 pct. af voldssagerne. Ifølge telefonundersøgelsen havde 34 pct. af grønlænderne oplevelse, at det var sådan, det forholdt sig; 27 


\section{Flemming Balvig}

pct. at det var mere end halvdelen (heraf 8 pct. at det drejede sig om 90-100 pct. af voldssagerne) og 39 pct., at det var mindre end 30 pct. (heraf godt hver fjerde, 26 pct., at det var mellem 0 og 10 pct.).

38. Ved den første spørgerunde i fokusgrupperne var der 74 pct., der ville idømme ubetinget anstaltsanbringelse; ved den anden spørgerunde 65 pct., og så altså 56 pct. ved den tredje og sidste spørgerunde. Ved den første spørgerunde var der 22 pct., der ville idømme 2 års anstaltsanbringelse eller mere, ved den anden spørgerunde 21 pct., og ved den tredje og sidste 16 pct.

39. Personlig kommunikation fra direktør i den grønlandske kriminalforsorg, Han Jørgen Engbo.

40. Personlig kommunikation fra direktør i den grønlandske kriminalforsorg, Han Jørgen Engbo. I januar og februar 2015 har det gennemsnitlige daglige belæg været endnu lavere end i 2014 og i særdeleshed 2013. Det har været på 116, og har således været hele 33 pct. mindre end i 2013.

41. Siden 2010 ser det ud som om stigningen er ophørt, eller i hvert fald, indtil videre, stilnet af.

42. At der i skrivende stund (2015) på en gennemsnitsdag er anbragt 3-4 gange så mange i anstalt i Grønland sammenlignet med, hvor mange der sidder indsat i fængsel i Danmark, skyldes for en væsentlig del forskelle i kriminalitetsmønsteret. Trods de ændringer med skærpelse af foranstaltningerne, der er sket - og sådanne er også sket i Danmark de senere år - så forholder det sig stadig sådan, at væsentlige grupper af personforbrydelser i Grønland, dels i mindre omfang overhovedet pådømmes i form af anstaltsanbringelse, og dels i kortere tid, hvis der bliver tale om anstaltsanbringelse. Dette fremgår i et vist omfang også af de praksisundersøgelser, der har været en del af de grønlandske og danske retsbevidsthedsundersøgelser (se tillige Breinholt Larsen, 2002). Når tallet for anstaltsanbragte på baggrund af personforbrydelser alligevel bliver betydeligt højere i Grønland, skyldes det den langt større forekomst af disse forbrydelser, den større opdagelses-/anmeldelseshyppighed og den højere opklaringshyppighed. Der er ikke tale om, at lovovertrædelser generelt pådømmes mildere i Grønland end i Danmark. Det varierer fra sagsområde til sagsområde, og der er også forhold, hvor der gennemgående dømmes mildere i Danmark (Vestergaard, 1999), men for det mest relevante område her, personforbrydelserne, er den generelle tendens, at der i Grønland mindre ofte anvendes ubetinget anstaltsanbringelse/fængsel, at dommene til ubetinget anstaltsanbringelse/fængsel er relativt kortere. Det nødvendige grundlag for mere præcist at kunne beregne, hvor meget af dette, der forklarer den samlede forskel mellem anstaltsbrug i Grønland og brug af fængsler i Danmark, foreligger desværre ikke. Fra en række analyser ved vi, at mange andre forhold end kriminalitetens størrelse og karakter, kan influere på, hvor hyppigt og hvor lange frihedsberøvelser, der anvendes i et samfund, og at disse andre forhold ofte er de vigtigste (jf. bl.a. Aebi \& Kuhn, 2000; Barcley, 2000; Lappi-Seppalä, 2010; 2011). 